Review

\title{
From Austenitic Stainless Steel to Expanded Austenite-S Phase: Formation, Characteristics and Properties of an Elusive Metastable Phase
}

\author{
Francesca Borgioli (D) \\ Department of Industrial Engineering, University of Florence, via S. Marta 3, 50139 Florence, Italy; \\ francesca.borgioli@unifi.it; Tel.: +39-055-275-8734
}

Received: 30 December 2019; Accepted: 19 January 2020; Published: 28 January 2020

\begin{abstract}
Austenitic stainless steels are employed in many industrial fields, due to their excellent corrosion resistance, easy formability and weldability. However, their low hardness, poor tribological properties and the possibility of localized corrosion in specific environments may limit their use. Conventional thermochemical surface treatments, such as nitriding or carburizing, are able to enhance surface hardness, but at the expense of corrosion resistance, owing to the formation of chromium-containing precipitates. An effective alternative is the so called low temperature treatments, which are performed with nitrogen- and/or carbon-containing media at temperatures, at which chromium mobility is low and the formation of precipitates is hindered. As a consequence, interstitial atoms are retained in solid solution in austenite, and a metastable supersaturated phase forms, named expanded austenite or S phase. Since the first studies, dating 1980s, the S phase has demonstrated to have high hardness and good corrosion resistance, but also other interesting properties and an elusive structure. In this review the main studies on the formation and characteristics of $S$ phase are summarized and the results of the more recent research are also discussed. Together with mechanical, fatigue, tribological and corrosion resistance properties of this phase, electric and magnetic properties, wettability and biocompatibility are overviewed.
\end{abstract}

Keywords: austenitic stainless steels; expanded austenite; S phase; low temperature treatments; low temperature nitriding; low temperature carburizing; surface engineering

\section{Introduction}

Stainless steels are an important class of iron (Fe)-based alloys, which owe their name to their capability to resist to general corrosion in many environments, so that staining or rusting is avoided. In order to obtain this high corrosion resistance chromium $(\mathrm{Cr})$ must be added in a content of at least 10.5 wt.\%, so that an adherent, self-healing Cr-rich oxide film is able to form on the steel surface [1]. Nowadays stainless steels are employed in a plenitude of applications, from low-end ones, such as furniture or kitchenware, to sophisticated ones, such as components for chemical and power engineering industries, body implants or coronary stents [1-3]. Among the different classes of stainless steels, the largest one in term of alloys and market share is constituted by austenitic stainless steels, because they have excellent corrosion resistance, ease of formability and weldability, and they can be employed from cryogenic temperatures to elevated ones [1,2]. In these alloys the face-centered cubic (fcc) structure of austenite is stabilized by the presence of austenite-forming elements, like nickel (Ni), manganese $(\mathrm{Mn})$ and nitrogen $(\mathrm{N})$. Ni, with the content of $8 \mathrm{wt}$.\% or higher, is the basis of AISI 300 series stainless steels, which are widely used. Ni is partly substituted by Mn and N in AISI 200 series 
stainless steels, which have a higher strength and are cheaper than AISI 300 grades, but they can show a lower corrosion resistance [4]. As alloy element, $\mathrm{N}$ is a useful tool for increasing strength [3,5-9], fatigue properties $[3,6,7,10]$, wear resistance [6,7] and localized corrosion resistance $[3,7,11,12]$. A small $\mathrm{N}$ content is added in traditional steels, as AISI 316LN (about 0.1-0.6 wt.\%), while larger amounts are present in the "high- $\mathrm{N}$ " stainless steels ( $>0.4 \mathrm{wt} . \%$, according to Speidel [13]). As austenite-stabilizing element, it is employed together with $\mathrm{Mn}$ in the so called Ni-free stainless steels $[3,9,13]$.

As drawbacks, austenitic stainless steels have low hardness and poor tribological properties, which may affect the performances of components subjected to wear, and they may suffer localized corrosion in specific environments, as in chloride-ion containing solutions. These limitations can be overcome using surface engineering techniques, which are able to modify the surface characteristics of the components by means of either coating with hard compounds, obtained with processes such as physical vapor deposition (PVD), chemical vapor deposition (CVD) or plasmaspray, or modifying the surface layers by means of diffusion processes [14]. Surface alloying of low alloy steels or tool steels with $\mathrm{N}$ and/or carbon (C) using diffusion processes is a well-known and effective industrial practice, which cannot be straightforwardly transferred to stainless steels. As an example, low alloy steels and tool steels are usually nitrided at temperatures in the range $500-580{ }^{\circ} \mathrm{C}$ and the obtained modified surface layers consist of an outer compound layer, in which Fe-based nitrides $\gamma^{\prime}-\mathrm{Fe}_{4} \mathrm{~N}$ and $\varepsilon-\mathrm{Fe}_{2-3} \mathrm{~N}$ are present, and a diffusion layer, in which $\mathrm{N}$ is solubilized in ferrite and small alloy element nitride precipitates form [15]. For austenitic stainless steels, the temperatures usually employed for nitriding or carburizing treatments promote the precipitation of hard $\mathrm{Cr}$ compounds (nitrides, carbides), so that that the Cr-depleted matrix is not able to form a uniform and protective passive film and corrosion can easily occur [3,16]. Moreover, the oxide passive layer of these alloys, if it is not previously removed, impedes a uniform treatment, hindering the uptake of interstitial elements from the treatment atmosphere into the substrate [16].

It is now well assessed that, when operating at low temperatures, i.e., at temperatures at which $\mathrm{Cr}$ diffusion is very low while interstitial atoms are able to diffuse (usually $\leq 450{ }^{\circ} \mathrm{C}$ for nitriding $[3,17]$ and $\leq 550{ }^{\circ} \mathrm{C}$ for carburizing [17]), it is possible to inhibit the formation of nitride or carbide precipitates and to obtain modified surface layers which consist mainly of a metastable supersaturated phase, so that hardness is improved without impairing corrosion resistance.

The discovery of the beneficial effects of low temperature nitriding and the possibility of producing, in austenitic stainless steels, a phase now known as expanded austenite or S phase is usually dated at mid-1980 and ascribed to the independent studies of Ichii et al. [18] and Zhang and Bell [19]. As a matter of fact, these groups were not the only ones that, more or less in the same period, discovered that, when operating at a temperature of about $400{ }^{\circ} \mathrm{C}$, something new and unexpected formed. In 1983 Zhang and Bell presented a study at an international congress, which was summarized as an abstract in the proceedings [20], and they claimed that "low temperature plasma nitriding at $400^{\circ} \mathrm{C}$ can produce a nitrided layer which has anticorrosion properties equivalent to the original material". The regular paper on this topic was published in 1985 [19], and here it was reported that, according to an unpublished work dated 1984, plasma nitriding at $400{ }^{\circ} \mathrm{C}$ produced a $\mathrm{CrN}$-free surface layer, which was supposed to be composed of mixed $\gamma^{\prime}-\mathrm{Fe}_{4} \mathrm{~N}$ and austenite. In 1984, at an Italian congress, De Benedetti et al. [21] reported that plasma nitriding AISI 316 steel at $400{ }^{\circ} \mathrm{C}$ produced a new phase, named $\varepsilon^{\prime}$, which was supposed to be of the type $(\mathrm{Fe}, \mathrm{Cr}, \mathrm{Ni}, \mathrm{Mo})_{2} \mathrm{~N}_{1-\mathrm{x}}$, similar to the tetragonal FeNiN nitride. The regular article on an Italian journal (in Italian) was published in 1985 [22], and only in 1988 their study on this "new" phase was reported in an international journal, but it regarded combined plasma nitriding treatments at high $\left(500\right.$ or $\left.600^{\circ} \mathrm{C}\right)$ and low $\left(400{ }^{\circ} \mathrm{C}\right)$ temperature [23]. The first studies of Ichii et al. were reported in a Japanese journal (in Japanese) in 1985 [24], and the layer formed on SUS 304 (equivalent to AISI 304), plasma nitrided at $400{ }^{\circ} \mathrm{C}$, was ascribed to 
$\gamma^{\prime}-\mathrm{M}_{4} \mathrm{~N}(\mathrm{M}=\mathrm{Fe}, \mathrm{Cr}, \mathrm{Ni} \ldots$ ). Their well-known paper in English dated 1986 [18], and here the authors observed that in the X-ray diffraction patterns of SUS 304 specimens plasma nitrided at $400{ }^{\circ} \mathrm{C}$, beyond the peaks of austenite, five extra peaks were present, which were shifted to lower diffraction angles in respect to austenite peaks. These shifted peaks, named S1-S5, were not indexed in the ASTM index, so the authors indicated the new phase as "S" phase, and supposed, also taking into account its ferromagnetism, that it was a type of $\mathrm{M}_{4} \mathrm{~N}$. In the same year, Yasumaru and Kamachi performed a similar study [25], the glow-discharge nitriding of AISI 304 at $350{ }^{\circ} \mathrm{C}$, and they found similar X-ray diffraction patterns, but they supposed that the shifted peaks could be ascribed to a face-centered tetragonal (fct) nitride, named $\mathrm{Y}_{\mathrm{N}}$.

It is hard to say whether these studies were really independent, or they were more or less influenced by each other. The nitriding of austenitic stainless steels was made easier by plasma techniques, which allowed to remove the surface oxide layers, so that treatments at temperatures in the range $495-565{ }^{\circ} \mathrm{C}$ were well established since 1970s [26,27]. Nitriding at lower temperature has been reported in literature, as in the technical note of Lerner [28], which was dated 1972 and showed the effects of glow-discharge nitriding at temperature as low as $450{ }^{\circ} \mathrm{C}$ on AISI 304 , or in the paper of Spalvins [29], that was dated 1983 and regarded nitriding of low alloy steels and AISI 304 at $350{ }^{\circ} \mathrm{C}$, but the formation of something new was not recognized. On the contrary, in studies on $\mathrm{N}$ ion implantation the lattice expansion of austenite was registered, and it was hypothesized that $\mathrm{N}$ was retained in solid solution [30].

The beginning of low temperature carburizing is less uncertain, as recently reviewed by Christiansen and Somers [31], and it dates back to 1983, when Kolster reported, in a technical paper in German, a new process able to improve the wear and fatigue resistance of stainless steels without impairing the corrosion resistance [32]. This process, which was the basis of the proprietary treatment known as Kolsterizing, was probably inspired by previous studies [33] regarding the carburizing reaction occurring between stainless steels and liquid sodium, used as cooling medium in liquid-metal fast-breeder reactors and containing small amounts of $\mathrm{C}$, in which Kolster was also involved since 1970s [34].

As the observed "new" phase had many fathers, it also had many names. As recalled previously, Ichii et al. [18] referred to it as a " $S$ " phase, De Benedetti et al. [21,22] named it $\varepsilon^{\prime}$, and Yasumaru and Kamachi $Y_{N}$ [25]. The "S phase" name was adopted by Bell [17]. A few years later Hannula et al. [35] referred to it as "expanded austenite", Williamson et al. [36] as $\gamma_{N}$, which indicated "a high nitrogen fcc phase" and Marchev et al. [37] as " $m$ " phase, due to its characteristics of martensite phase, i.e., a supersaturated solid solution originating from austenite. Today the most used names are "expanded austenite", "S phase", $\gamma_{N}$ (for the N-rich one) and $\gamma_{C}$ (for the C-rich one). Even if it is indeed true that this phase derives from an expansion of austenite lattice, many studies have shown that the characteristics of this phase are beyond a simple expansion of austenite lattice, though someone can be related to it. In the present review, the name "S phase" has been chosen, using it with the original meaning, i.e., a phase having its diffraction peaks shifted as compared with those of austenite.

From the early studies, much research has been carried out on the formation, characteristics and properties of the modified surface layers produced with low temperature surface treatments of austenitic stainless steels, due to the attractive characteristics of the $S$ phase. In fact, this phase allows to enhance significantly surface hardness (up to $1450 \mathrm{HV}$ for nitriding treatments [38] and up to $1000 \mathrm{HV}$ for carburizing treatments [39]), wear and fatigue resistance and it is able to delay corrosion phenomena in chloride-ion containing solutions. Up today more than a thousand of papers have been published in academic journals, conference proceedings and professional reports on this subject. While the research has flourished, the scale-up of some of the treatments used in these studies from laboratories to production processes has been difficult, due to technological barriers [40]. However, plasma, gas and salt bath processes are now commercially available [40]. 
The low temperature surface treatment of austenitic stainless steel has been recognized as an important topic of surface engineering, and both briefs overviews, on general or on specific topics $[17,31,41-46]$, and more extended reviews $[40,47,48]$ also have covered it recently. From the critical review of Dong [47], dating a decade ago, research has proceeded, new techniques have been employed to study the modified surface layers and the $S$ phase, and new and interesting results have been reported, suggesting even the possibility that the $S$ phase cannot be considered only a supersaturated solid solution of interstitial atoms in austenite. This review has the aim of summarizing the main studies regarding the formation, characteristics and properties of the $S$ phase and the modified surface layers in which it is present, especially focusing on nitriding processes, which have been the most investigated. Regarding the properties of surface modified austenitic stainless steels, beyond the changes in hardness, tribological and fatigue properties and corrosion resistance, which are usually the most considered, this review reports the effects of the treatments on magnetic properties, electric properties, wetting behavior and biocompatibility.

\section{Types of S Phase}

In the face-centered cubic lattice of austenite interstitial atoms, like $\mathrm{N}$ and $\mathrm{C}$, are hosted in the octahedral interstitial site at the center of the cell (and in the equivalent sites), and each interstitial is surrounded by metal atoms in the neighboring lattice sites. The misfit strain associated with $\mathrm{N}$, and thus the lattice expansion, is larger than that caused by $\mathrm{C}$, even if the atomic radius of $\mathrm{N}$ is smaller than that of C [49].

According to phase diagrams, for pure Fe the maximum solubility of $\mathrm{N}$ in fcc $\gamma$-Fe is about 10.3 at. $\%$ at $650{ }^{\circ} \mathrm{C}$ [50], and the maximum solubility of $\mathrm{C}$ in $\gamma$-Fe is 9.23 at. $\%$ at $1147^{\circ} \mathrm{C}$ [51]. When an austenitic stainless steel as AISI 316 is taken into account, the equilibrium solubility in austenite is very low, $<0.65$ at.\% for $\mathrm{N}$ [47], while a C content lower than 0.015 at. $\%$ is employed in order to avoid carbide precipitation [52]. However, when low temperature treatments in $\mathrm{N}$ or $\mathrm{C}$ containing gas mixtures are carried out, the solubility of these interstitial atoms can reach values up to several hundred times higher than the equilibrium solubility. As a consequence, depending on treatment atmosphere, two supersaturated phase may form:

- $\quad \mathrm{N}$-rich S phase, with a N content up to $~ 38$ at.\% [53], also well beyond of that of $\gamma^{\prime}-\mathrm{Fe}_{4} \mathrm{~N}$ nitride (19.3-20 at.\% [50]), which maintains a fcc structure of the metal atoms;

- C-rich $S$ phase, with a C content up to 19 at.\% [54].

The profiles of the interstitial atoms as a function of depth are characteristic of low temperature treatments, and they are depicted in Figure 1. When nitriding is performed, $\mathrm{N}$ profile vs. depth shows high values at the surface, a steep decrease to lower values followed by a nearly constant plateau, and then a further steep decrease to matrix values $[42,47,55,56]$ (Figure 1a). For carburized samples, a steep decrease from the high values at the surface, followed by a smoother decrease to matrix values is observed $[42,47,55,56]$ (Figure 1b). The thickness of the modified surface layers usually ranges from a few $\mu \mathrm{m}$ to some tens of $\mu \mathrm{m}$, depending on the treatment parameters. However, studies on treatments performed at the same temperature for the same duration have shown that the depth of the modified layers is thicker for carburized samples if compared to that of nitrided ones $[47,55,56]$.

Both the $\mathrm{N}$ - and $\mathrm{C}$-rich $\mathrm{S}$ phases can be obtained using $\mathrm{N}$ - and $\mathrm{C}$-containing gas mixtures and carrying out the process as a single step or sequentially. The single step treatment is referred to either as nitrocarburizing, taking into account that it is a low temperature treatment [42], or as carbonitriding, since it is performed on alloys in an austenitic state [47]. Hereafter, this treatment is indicated as nitrocarburizing, regardless of the term used by the authors. Sequential treatments have been carried out performing either nitriding followed by carburizing [56] or carburizing followed by nitriding [56,57]. For all these treatment types, both an outer layer consisting of N-rich S phase and an inner C-rich S phase form. Taking into account the effect of both interstitial atoms, a smoother profile is obtained, in comparison with that obtained with a nitriding only treatment $[42,55,56,58]$ (Figure 1c). 

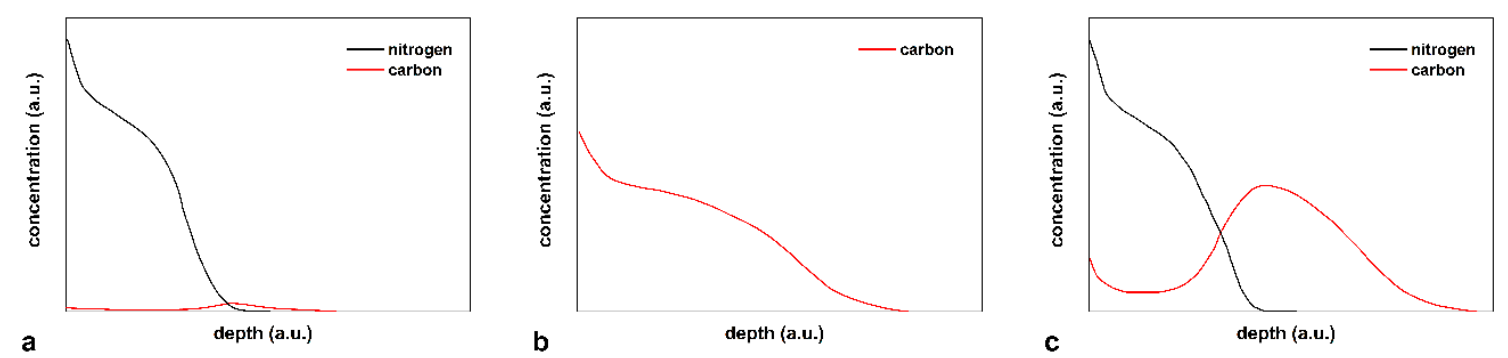

Figure 1. Qualitative N and/or C profiles vs. depth: (a) nitrided (as in ref. [42,55,59]); (b) carburized (as in ref. [42,55]); (c) nitrocarburized (as in ref. $[42,55,56,60])$ austenitic stainless steels.

\section{Formation of $S$ Phase}

\subsection{Factors Influencing $S$ Phase Formation}

At the operating temperatures that are usually employed for the treatment of low alloy steels or tool steels (500-580 ${ }^{\circ} \mathrm{C}$ for nitriding and $850-950{ }^{\circ} \mathrm{C}$ for carburizing), in austenitic stainless steels a significant diffusion of $\mathrm{Cr}$ atoms occurs, so that, due to the high affinity of $\mathrm{Cr}$ to $\mathrm{N}$ or $\mathrm{C}$, large amounts of $\mathrm{Cr}$ nitrides or carbides are able to form. Otherwise, when low temperature treatments are performed, the diffusivity of interstitial atoms $(\mathrm{N}$ and $\mathrm{C}$ ) is several orders of magnitude higher than that of substitutional elements (as $\mathrm{Fe}, \mathrm{Cr}$, $\mathrm{Ni}$ or $\mathrm{Mn}$ ), which are relatively "immobile" in the lattice [36]. The formation of nitrides or carbides, which should be thermodynamically favored, is hindered and the interstitial atoms are apparently retained in solid solution, causing the observed "colossal" supersaturation, as called by Cao et al. [52] and Christiansen and Somers [53].

The transition from an interstitial solubilization to the formation of an austenite matrix containing nitrides or carbides is usually depicted in a time-temperature-transformation plot $[17,46]$. At high temperatures, as $1150{ }^{\circ} \mathrm{C}$, a $\mathrm{N}$ solubilization can occur with high $\mathrm{N}_{2}$ pressures [59]. As treatment temperature is lowered, longer treatment durations are needed in order to produce nitride precipitation.

Similar plots do not take into account that other factors may influence nitride (or carbide) precipitation. The feeding of interstitial atoms is an important factor, which influences the formation of precipitates. Regarding plasma nitriding, it has been shown [61-63] that the decreasing of treatment pressure causes an increase of the ion and fast neutral energy, owing to the increase of voltage drop between the electrodes and the mean free path of the species present in plasma. As a consequence, an enhancement of nitriding efficiency and a greater $\mathrm{N}$ feeding occur [61-63], so that nitride precipitates are also able to form at temperatures at which this phenomenon should be delayed [62]. For example, although at $430{ }^{\circ} \mathrm{C} \mathrm{CrN} \mathrm{precipitation} \mathrm{in} \mathrm{AISI} 316$ occurs, according to Bell [17], for times longer than about $30 \mathrm{~h}$, a substantial amount of $\mathrm{CrN}$ precipitates can form in AISI 316L when using pressures of $500 \mathrm{~Pa}$ or lower for a 5-h treatment duration [62].

The formation of nitride or carbide precipitates is also influenced by the alloy elements present in the austenitic stainless steels. It is now known that $\mathrm{Cr}$, which is also a nitride-/carbide-forming element, promotes the formation of the S phase. Fe-Ni or Fe-Mn alloys, having a fcc structure, have been reported to be not able to form $\mathrm{S}$ phase $[64,65]$, but an expansion of the austenite fcc structure has been observed in ion-beam nitrided Invar (Fe-34Ni) [66] and in triode-plasma nitrided Invar $36^{\circledR}$ (Fe-36Ni) [67]. The presence of a fairly great content of Mn, like that present in AISI 200 series and $\mathrm{Ni}$-free austenitic stainless steels, tends to promote nitride formation at temperatures at which AISI 300 series stainless steels do not produce nitride precipitation, since $\mathrm{Mn}$ is a nitride-forming element $[55,68]$. For example, plasma nitriding of AISI 202 and AISI 316L samples at $400{ }^{\circ} \mathrm{C}$ and $500 \mathrm{~Pa}$ for $5 \mathrm{~h}$ or at $430{ }^{\circ} \mathrm{C}$ and $10^{3} \mathrm{~Pa}$ for $5 \mathrm{~h}$ caused the formation of sensible amounts of nitrides in AISI 202, while in AISI 316L specimens they were not detected [69]. Nitride precipitation is particularly relevant 
in Ni-free austenitic stainless steels [55], and thus it has been suggested that nitride-free modified layers are almost impossible to produce [47]. However, using temperatures as low as 360 or $380{ }^{\circ} \mathrm{C}$ and a pressure of $340 \mathrm{~Pa}$, nitride-free layers were obtained on a P558 (17.7 wt.\% Cr, 10.5 wt.\% Mn, 0.20 wt. \% C and 0.53 wt.\% N) steel [70]. Regarding AISI 300 series stainless steels, it has been shown that AISI 316L has a lower tendency to form nitrides, if compared to AISI 304L [71,72]. It has been hypothesized that molybdenum (Mo) atoms tend to stabilize the structure of the S phase attracting $\mathrm{N}$ atoms around themselves, so that $\mathrm{Cr}$ nitride precipitation is prevented [72]. Owing to the importance of alloy elements in the formation and stabilization of the $S$ phase, it has been suggested that alloy composition can be tailored adding nitride-forming elements, such as $\mathrm{Mo}$, $\mathrm{Ti}$ and $\mathrm{Al}$, in order to delay Cr nitride precipitation [73].

\subsection{Activation of the Surface of Austenitic Stainless Steels and Pre-Treatment Processes}

When low temperature treatments are carried out on austenitic stainless steels, the first and fundamental step, which allows to obtain a correct and homogeneous treatment of the specimens, consists of removing the passive film, which should hinder the diffusion of the interstitial atoms into the substrate. Plasma-based techniques, such as direct current (DC) $[17,37,45,63]$, pulsed DC [41,74-76], radio-frequency $(\mathrm{RF})$ [77-79] and active screen [80-82] plasma processes, and plasma-based ion implantation $[77,83]$ and ion beam implantation $[83,84]$ techniques take the advantage of the fact that during the process the ion bombardment of the sample surface allows both its cleaning and activation. In many studies and industrial processes this sputtering step is carried out as a pre-treatment before the low temperature treatment. Different gas mixtures, such as Ar [84], Ar- $\mathrm{H}_{2}$ [76], $\mathrm{N}_{2}-\mathrm{H}_{2}$ [45,76], have been used for this pre-treatment, and it has been shown that the gas mixtures influence the characteristics of the produced modified surface layers [76]. Recently Borgioli et al. [85] reported that, when performing a low pressure treatment with aN-containing atmospherewith conditions similar to cathodic sputtering, it is possible to activate the surface, heat the samples and obtain a significant incorporation of $\mathrm{N}$ atoms, so that thin modified surface layers consisting mainly of the $\mathrm{S}$ phase can be obtained in a fairly short duration.

For gas-based treatments the employed gaseous atmospheres are not usually able to remove the passive film, so that activation pre-treatments are required. Some activation treatments have been recently reviewed by Somers and Christiansen [86]. Stripping the passive film and replacing it with a thin metallic layer (nickel [57,87] or iron [88]) allow to prevent surface repassivation and can catalytically promote the dissociation of gaseous species at the surface. The passive film can also be removed using chemical etching [89], or with the addition of reactive compounds, as halogen-based ones, to the gaseous atmosphere [90], or using reducing gases as mixtures of acetylene-hydrogen atmospheres at high temperatures [86], or with ion sputtering [89,91]. Baranowska [89] and Baranowska et al. [91] pointed out that the activation process influences the $\mathrm{N}$ adsorption in gas nitriding treatment.

\subsection{Phenomena Influencing Interstitial Diffusion and S Phase Formation}

When nitriding, carburizing or nitrocarburizing treatments are performed, the interstitial atoms can diffuse in the substrate and concentration profiles like those depicted in Figure 1 are obtained. These profiles are different from the one that can be obtained with the standard analytic solution of the diffusion equation, which applies for concentration independent diffusion in a semi-infinite solid at constant surface concentration and for which the complementary error function can be used, or even from the profile which can be obtained nitriding a low alloy steel [92]. Comparing the thickness values of nitrided layers reported in literature with the diffusion values for $\mathrm{N}$ in fcc austenite, Williamson et al. [36] showed that, when $\mathrm{S}$ phase layers form during low temperature nitriding, $\mathrm{N}$ diffusion is four to five orders of magnitude faster than expected for $\mathrm{N}$ in fcc austenite, 
and the activation energy, evaluated as $140 \mathrm{~kJ} \mathrm{~mol}^{-1}$, is significantly reduced. Many efforts have been made in order to explain this enhanced diffusion, and many models have been suggested in order to correctly take into account the different phenomena which can influence it, and thus reproduce the experimental profile. The main effects which have been hypothesized to influence the enhanced diffusion and "colossal" supersaturation can be summarized as follows.

- Concentration-dependent diffusion. The diffusivity of interstitial atoms in the S phase seems to be dependent on their concentration and not by a composition gradient. Mandl et al. [93] calculated the $\mathrm{N}$ diffusivity from concentration profiles of $\mathrm{N}$-implanted samples and they found that $\mathrm{N}$ diffusivity depends on concentration, with a high value for high $\mathrm{N}$ content and low value for low concentration. It has been hypothesized that the increase of the lattice constant during $S$ phase formation changes the electron density distribution, so that an increase of diffusivity occurs due to the lowered potential barriers between two interstitial sites. The difference between the faster $\mathrm{N}$ diffusion in the $\mathrm{S}$ phase than in austenite is supposed to produce the plateau-shaped $\mathrm{N}$ profile with sharp leading edge. This model is also able to explain the shape of C profile vs. depth, which is more similar to an error function, since the C-rich $S$ phase has smaller lattice expansion than the N-rich S phase. Christiansen and Somers [94] determined the $\mathrm{N}$ diffusivity in the $\mathrm{S}$ phase from the stepwise de-nitriding kinetics of initially fully nitrided homogeneous and stress-free foils. The diffusion coefficient, fitted with a Lorentzian function, resulted to increase up to a $\mathrm{N}$ occupancy $y_{\mathrm{N}}$ (i.e., the degree of occupied octahedral interstial sites; in a fcc lattice is equivalent to the number of interstitial atoms per metal atom) of 0.45 (i.e., $~ 31$ at.\%) and then it decreased. For the same nitriding temperature $\left(420^{\circ} \mathrm{C}\right) \mathrm{N}$ diffusion coefficient in AISI 304 and AISI 316 was comparable up to $y_{\mathrm{N}}<0.45$, and then it was higher for AISI 316 than for AISI 304. The authors hypothesized that the occurrence of a maximum in the diffusion coefficient is related to an antagonistic effect due to $\mathrm{N}$ solubilization. $\mathrm{N}$ atoms are hosted in the octahedral interstice sites of fcc lattice. As more $\mathrm{N}$ atoms are solubilized, the lattice expands, an enlargement of octahedral and tetrahedral interstices occurs, the transfer of $\mathrm{N}$ atoms from an octahedral site to a tetrahedral interstice (which is considered the activate state for interstitial diffusion in fcc lattice) is facilitated, and thus the activation energy for $\mathrm{N}$ diffusion is reduced. As a consequence, $\mathrm{N}$ diffusivity increases as $\mathrm{N}$ content is higher. As $\mathrm{N}$ content increases more and more, the probability that a neighboring interstitial site is occupied is higher, reducing the probability that a $\mathrm{N}$ atom in the activated state can jump in an unoccupied site, thus hindering $\mathrm{N}$ diffusion.

- Trapping of $\mathrm{N}$ in $\mathrm{Cr}$ sites (trapping-detrapping model). Williamson et al. [95] hypothesized that the formation of a $\mathrm{N}$ supersaturated phase occurs due to $\mathrm{Cr}$ atoms, which tend to trap $\mathrm{N}$ atoms in the nearby octahedral sites, with the binding energy of trap sites higher than that of regular solution sites. When all $\mathrm{Cr}$ trap sites are occupied, additional $\mathrm{N}$ can rapidly diffuse through the $S$ phase layer to reach the leading edge of the $\mathrm{N}$ profile. This model was refined by Parascandola et al. [96], formalizing it with a diffusion equation which included not only trapping but also detrapping, that was suggested by the peculiar depth profile of ${ }^{15} \mathrm{~N}$ and ${ }^{14} \mathrm{~N}$ sequentially implanted [97]. More recently $\mathrm{N}$ mobility in austenite lattice was also assessed by Christiansen et al. [98] using sequential plasma and gas nitriding with $\mathrm{N}$ isotopes. On the basis of previous observations of the nitriding and de-nitriding of AISI 316 thin foils, according to which a fraction of $\mathrm{N}$ content of about 15 at.\% was not fully retractable in a reducing atmosphere of flowing hydrogen while a $\mathrm{N}$ content in the range of $15-38.1 \%$ was fully retractable [53], the authors hypothesized that at least two states of $\mathrm{N}$ bonding in a homogeneous $\mathrm{S}$ phase are present, and non-retractable $\mathrm{N}$ is associated with short-range ordering with $\mathrm{Cr}$. Their experimental study [98], 
in which AISI 316 samples were plasma nitrided with ${ }^{15} \mathrm{~N}$-enriched $\mathrm{N}_{2}$ gas, then gas nitrided in ${ }^{14} \mathrm{NH}_{3}$ and at last gas de-nitrided in $\mathrm{H}_{2}$ for $\mathrm{N}$ retraction, confirmed this hypothesis, and showed that ${ }^{15} \mathrm{~N}$ atoms, incorporated at the surface with plasma nitriding, were indeed redistributed by the subsequent gaseous nitriding under the influence of a ${ }^{14} \mathrm{~N}$ concentration gradient.

- Stress-assisted diffusion. The high compressive residual stresses, which are produced in the nitrided layer as a consequence of the high expansion of the fcc lattice due to N solubilization, are able to influence $\mathrm{N}$ concentration at the surface, as well as its diffusivity. According to Christiansen and Somers [94], the $\mathrm{N}$ chemical potential depends not only on $\mathrm{N}$ activity and temperature, but also on hydrostatic stress derived from compressive residual stresses parallel to the surface. As a consequence, the compressive elastic stress acts to change $\mathrm{N}$ surface concentration in the stressed $S$ phase, in comparison with unstressed one. The stress induced by the concentration gradient of $\mathrm{N}$ atoms in the solid affects $\mathrm{N}$ diffusion, because the elastic field is capable of creating an additional component of the driving force for $\mathrm{N}$ transport. Stress-induced diffusion has been included to model $\mathrm{N}$ diffusion considering concentration-independent diffusion [99], concentration-dependent diffusion $[100,101]$, and concentration-dependent diffusion combined with trapping effect [102], and a good reproducibility with experimental data has been obtained.

Besides these effects, other phenomena may influence $\mathrm{N}$ diffusion. In particular, it has been observed that $\mathrm{N}$ concentration and penetration depth are different for the different crystallographic orientations and, referring to the different planes, they increase in the order $(111)<(110)<(001)[103,104]$. Martinavičius et al. [103] observed that $\mathrm{N}$ diffusivity varied with surface orientation during ion nitriding, but it was isotropic during annealing after nitriding, and they hypothesized that this behavior was related to irradiation effects on the surface. Wu et al. [104] registered different surface $\mathrm{N}$ concentrations and depths for grains with different orientations in gas nitrided AISI 316L samples. These authors, also taking into account other studies, hypothesized that the different $\mathrm{N}$ diffusion in differently oriented grains can be ascribed to both different $\mathrm{N}$ concentrations at the surface and differences in residual stress for different grains, since AISI 316L is elastically anisotropic. In fact, the elastic modulus is the greatest for $<111>$ direction and the smallest for $<100>$ one, so that the compressive stress tends to increase fastest in $<111>$-oriented grains and slowest in $<100>$-oriented grains, which are more compliant. Elastic anisotropy in stress-assisted diffusion was recently considered in a kinetic model developed by Moskalioviene and Galdikas [105], in which the anisotropy of absorption was also taken into account. A recent multi-physics thermo-chemical-mechanical model combined 1-dimensional $\mathrm{N}$ diffusion in the depth direction with a concentration-dependent diffusivity, elasto-plastic accommodation of the lattice expansion, stress-gradient-induced diffusion of $\mathrm{N}$ atoms, solid solution-strengthening by $\mathrm{N}$ and trapping of $\mathrm{N}$ by $\mathrm{Cr}$ atoms, and it obtained a very good agreement between the predicted and experimental composition-depth profiles [106]. The model also allowed to evaluate the compositional, thermal, plastic and elastic contributions to the strain, induced on austenite lattice due to the formation of the $S$ phase, and to obtain a trend of the residual compressive stresses in the surface layers.

\subsection{Thermal Stability and Decomposition of the S Phase}

The $S$ phase is a metastable phase, and thus it tends to transform both when the treatment temperature is too high and duration is too long, and when the service temperature is too high. It has been observed that from the N-rich $S$ phase $\mathrm{CrN}$ tends to form [17], while from the C-rich $\mathrm{S}$ phase Cr-based carbides $\mathrm{M}_{23} \mathrm{C}_{6}$ and $\mathrm{M}_{7} \mathrm{C}_{3}$ and Fe-based Hägg carbide $\chi-\mathrm{M}_{5} \mathrm{C}_{2}$ tend to form [54]. 
By using isothermal annealing procedures of nitrided or carburized specimens several authors have studied the thermal stability of the S phase and its decomposition. The study of Li [107] on AISI 316 plasma nitrided specimens annealed from 100 to $600{ }^{\circ} \mathrm{C}$ for durations as long as to $3000 \mathrm{~h}$ showed that $\mathrm{S}$ phase tends to decompose forming $\mathrm{CrN}$ and body-centered cubic (bcc) $\alpha$-Fe, while the fcc phase is progressively depleted in $\mathrm{N}$. The incubation time for this transformation ranges from minutes at $500{ }^{\circ} \mathrm{C}$ to thousands of hours at $300{ }^{\circ} \mathrm{C}$, and it has been hypothesized that years are needed for the decomposition at $300^{\circ} \mathrm{C}$ or below. A similar result was found by Christiansen and Somers [108], but these authors pointed out that temperature and time of the transformation also depend on alloy composition. When studying the decomposition kinetics of AISI 304L and AISI 316L specimens, subjected to gas nitriding at $430{ }^{\circ} \mathrm{C}$ for $28 \mathrm{~h}$, by means of isothermal annealing from 30 to $900{ }^{\circ} \mathrm{C}$ in inert $\left(\mathrm{N}_{2}\right)$ and reducing $\left(\mathrm{H}_{2}\right)$ atmospheres, they observed that the AISI 316L steel tends to be more stable than AISI 304L. In a reducing atmosphere the S phase in AISI 304L decomposes in $\alpha-\mathrm{Fe}+\mathrm{CrN}$, while for AISI 316L $\gamma$-Fe and $\mathrm{CrN}$ form. The formation of a lamellar structure consisting of $\alpha$-Fe and $\mathrm{CrN}$ has also been reported for AISI 316 nitrided at high temperatures [109], while dendritic structures of $\alpha$-Fe and CrN have been observed at grain boundaries and inside the grains of AISI 316 nitrided with $\mathrm{RF}$ and plasma immersion ion implantation processes [77]. The decomposition of the $\mathrm{S}$ phase and the formation of $\alpha-\mathrm{Fe}$ and $\mathrm{CrN}$ have also been observed for AISI 304L and the Mn-rich Staballoy AG17 ${ }^{\circledR}$, while in the Ni-rich RA $330^{\circledR}$ steel the S phase has decomposed in $\mathrm{Cr}+(\mathrm{Ni}$-stabilized) $\gamma$-Fe [110]. The delayed $\mathrm{CrN}$ formation in Mo-containing stainless steels was also registered by Mändl et al. [111], who showed that in ion implanted X6CrNiTi18.10 specimens $\mathrm{CrN}$ was able to form after $2 \mathrm{~h}$ at $425^{\circ} \mathrm{C}$, while it was not observed in $\mathrm{X} 6 \mathrm{CrNiMoTi17.12.2.}$

Regarding the thermal stability of the C-rich $\mathrm{S}$ phase, studies on the isothermal annealing of AISI 316, carburized at $450^{\circ} \mathrm{C}$ for $20 \mathrm{~h}$, have shown that the temperature, at which decomposition occurs in thousands of hour, is $350^{\circ} \mathrm{C}$, that is higher than that of nitrided samples [112]. Hägg carbide $x-\mathrm{M}_{5} \mathrm{C}_{2}$ and $\mathrm{M}_{7} \mathrm{C}_{3}$ form in a S-phase zone with a $\mathrm{C}$ content of 10.7 at. $\%$ at the surface after prolonged carburizing at $475{ }^{\circ} \mathrm{C}$ up to $44 \mathrm{~h}$ [113]. A study on gaseous carburizing of AISI 316 foils and powder in the range $380-470{ }^{\circ} \mathrm{C}$ showed that the formation of Hägg carbide in the $\mathrm{S}$ phase happens regardless of the treatment temperature, when the $\mathrm{C}$ content in $\mathrm{S}$ phase exceeds the metastable solubility limit (19 at.\%), and the decomposition of $\chi-\mathrm{M}_{5} \mathrm{C}_{2}$ into $\mathrm{M}_{7} \mathrm{C}_{3}$ occurs when the carburizing treatment is prolonged or the samples are maintained at temperatures above $600{ }^{\circ} \mathrm{C}$ [54]. When the annealing of homogeneously carburized powder has been carried out, for a $\mathrm{C}$ content of about 5.3 at.\% mainly $\mathrm{M}_{23} \mathrm{C}_{6}$ has developed, while for a $\mathrm{C}$ content of about 13 at. $\% \mathrm{M}_{7} \mathrm{C}_{3}$ has been detected, but $\chi-\mathrm{M}_{5} \mathrm{C}_{2}$ has not been observed [31,48].

On the basis of the extrapolations of experimental data it has been supposed that S-phase layers have a long term stability ( $>10$ years) when the service temperature is lower than about $200{ }^{\circ} \mathrm{C}[107,108,112]$.

\section{Characteristics of the S Phase}

\subsection{Surface Morphology}

The formation of modified surface layers, consisting of $S$ phase, also influences surface morphology, as depicted in Figures 2 and 3. The peculiar surface features of low temperature nitrided austenitic stainless steels, such as well delineated grain boundaries, slip bands and reliefs, were noted as early as 1986 by Yasumaru and Kamachi [25], and then reported by many authors [62,70,110,114-120]. These features result enhanced in plasma-based nitriding processes, especially at low pressures $[62,114,117]$, due to the more intense etching effects of ion bombardment, which affects more or less the grains depending on their orientation [121], but they have also been observed for gas nitrided specimens $[118,119]$. 

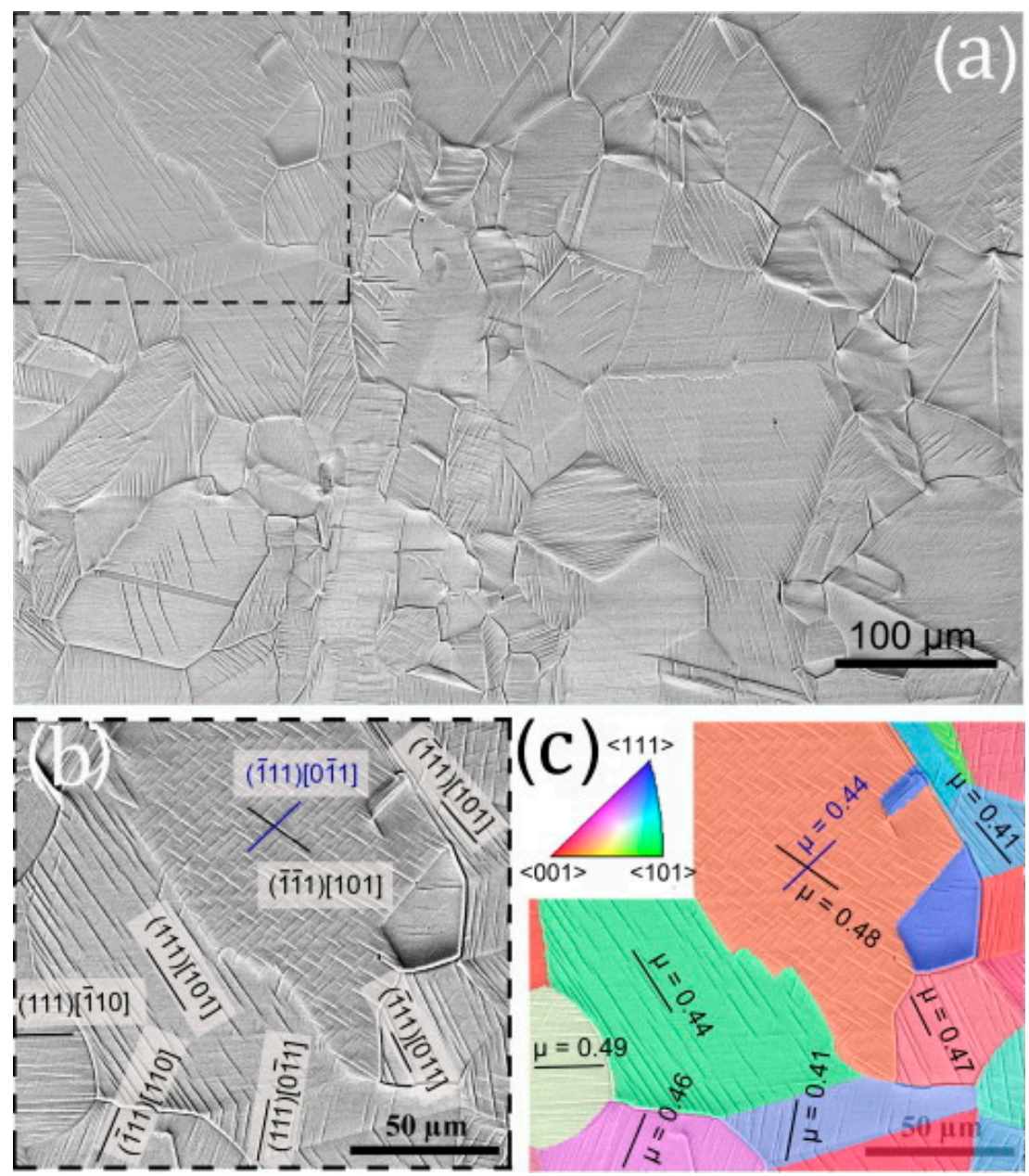

Figure 2. Surface morphology of an AISI 316L sample plasma nitrided at $400{ }^{\circ} \mathrm{C}, 3 \mathrm{~h}$ : (a) Scanning electron microscopy (SEM) image; (b) detail with the activated slip systems; (c) electron backscatter diffraction (EBSD) mapping of the image (b) with the calculated Schmid factor. For further details, see [120]. (Reprinted from Acta Materialia, 83, J.C. Stinville, J. Cormier, C. Templier, P. Villechaise, Modeling of the lattice rotations induced by plasma nitriding of 316L polycrystalline stainless steel, 10-16, Copyright (2015), with permission from Elsevier).

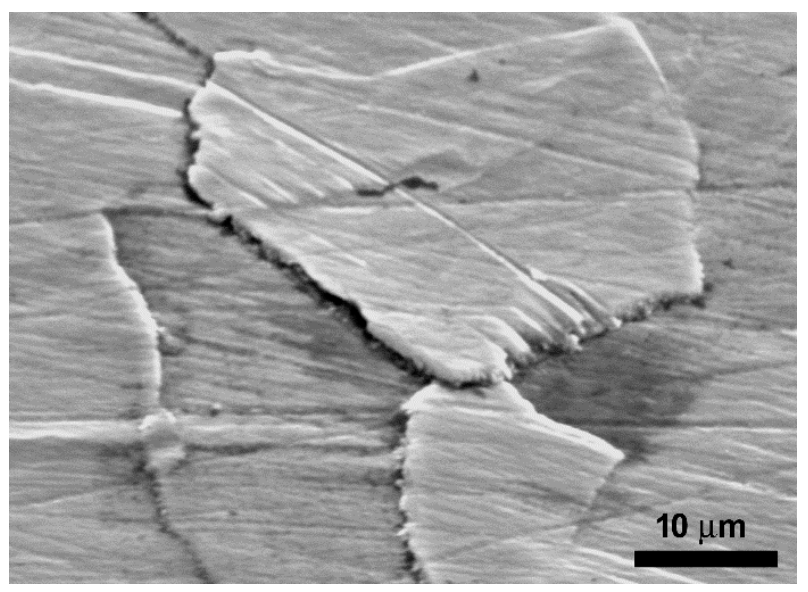

Figure 3. Detail of the surface morphology of an AISI $316 \mathrm{~L}$ sample plasma nitrided at $430{ }^{\circ} \mathrm{C}, 10^{3} \mathrm{~Pa}$, $5 \mathrm{~h}$. For further experimental details, see [116]. 
$\mathrm{N}$ solubilization in fcc austenite well beyond the solubility limit causes a large lattice expansion in the part of the grains affected by nitriding. Since each grain is constrained by its neighbors, the expansion parallel to the surface tends to be inhibited, leaving the morphology of the grains at the surface more or less unchanged, and high internal compressive stresses develop. Even if the yield stress is increased by solid solution strengthening, all these compressive stresses cannot be accommodated only elastically, so that, when these stresses exceed the critical shear stress, local plastic deformation phenomena occur, the effects of which are easily observable at the surface. Slip bands are present inside the grains, crossing them in different directions depending on crystallographic orientation, in some grains a chess-board like morphology is present when two slip systems are activated, relieves are observed at grain boundaries as a consequence of a swelling effect, and some grain boundaries lean forward on adjacent grains. For treatments having long durations, as those carried out by Stinville et al. [122] on AISI 316L at $400{ }^{\circ} \mathrm{C}$ for $33 \mathrm{~h}$, cracks and the beginning of delamination are also observable. According to Stinville et al. [120], the slip systems are those typical of a plastically deformed fcc metal, with $<110>$ slip directions in $\{111\}$ glide planes. The strain associated with plasticity in the direction perpendicular to the nitrided surface depends on grain orientation and, taking into account the swelling of the grains in comparison with the thickness of the nitrided layer, it has been estimated to reach values as high as $20 \%$ [123]. This elongation cannot be obtained only as a consequence of the expansion of the crystal lattice due to $\mathrm{N}$ solubilization (about $9 \%$ at the surface for a $\mathrm{N}$ concentration of $\sim 33$ at.\%, taking into account the change of lattice parameter [123]), so the effect is supposed to be also caused by elastic strain, originated by in-plane biaxial residual stresses, and plastic strain. Plastic deformation occurs when resolved shear stress reaches a critical value, which is probably due to a critical value of solubilized $N$ atoms. Stinville et al. [123] hypothesized that plastic deformation is initiated close to the nitriding front where $\mathrm{N}$ concentration increases from 0 to 15 at.\% and then it extends in the nitrided layer with the forward movement of the nitriding front.

X-ray diffraction analysis of single crystals and polycrystalline specimens subjected to ion beam nitriding [124] and EBSD mapping of polycrystalline specimens subjected to plasma nitriding [122,125] have shown that the rotation of crystal lattice in the nitrided region of the grains occurs. Due to the plastic anisotropy of the fcc lattice and the interaction with the neighboring grains, in polycrystalline specimens the rotation angle amplitude and direction of each grain depend on its orientation before nitriding and $\mathrm{N}$ concentration [122,125], but, overall, the texture tends to evolve towards the $<001>$ and/or $<111>$ orientations $[46,122,125]$. Lattice rotations up to $3^{\circ}$ toward $<111>$ and up to $4^{\circ}$ toward

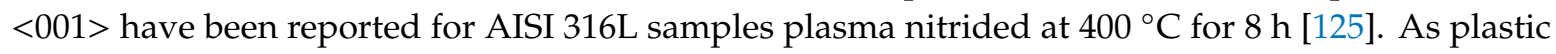
deformation begins, a continuous increase of lattice rotation occurs as $\mathrm{N}$ content increases, so that a gradient of lattice rotation associated with the gradient of $\mathrm{N}$ concentration has been observed [126]. As pointed out by Stinville et al. [125], the trend of the observed plastic rotation is similar to that observed on polycrystalline aluminum subjected to tensile test, suggesting that this plasticity effect is equivalent to that produced by a tensile elongation along the normal surface [120]. Additionally, the swelling effect is dependent on grain orientation, so that the swelling of the near-oriented $<100>$ grains is higher than the swelling of the near-oriented $<111>$ or $<101>$ grains [123].

It is interesting to note that the features caused by plastic deformations are well observable on samples which have been polished before nitriding, while they are not observable on rougher surfaces [127], which are probably able to better accommodate plastic deformations.

The occurrence of plastic deformations, swelling and grain rotation influences not only surface morphology but also surface roughness of the samples, which tend to increase $[70,117,128]$. In plasma treated samples ion bombardment also affects surface roughness, since a plasma etching occurs [117].

Surface features, similar to those observed in nitrided specimens, are also observable on samples subjected to carburizing with the Kolsterising process $[129,130]$ or with plasma process [131], and plastic deformation and grain rotation have been observed [131]. 


\subsection{Microstructure and Phase Composition of the Modified Layers}

Since the early publications on this topic, the modified surface layers produced with low temperature treatments have been reported to be a nearly featureless layer, in comparison with the etched matrix. This resemblance to the compound layer formed in nitrided low alloy steels, suggested that the "new" phase produced with nitriding treatment might be a nitride [18,21,22,25,64], or a mixing of nitride and austenite matrix [19]. By comparing the micrographs present in literature it may be argued that this featureless appearance was probably due the type of chemical etching used to outline the layer. Etchants as a solution of $\mathrm{HCl}$ and $\mathrm{H}_{2} \mathrm{O}_{2}$ [18], nital [21,22] or Marble's reagent [19] seemed to be not able to etch $\mathrm{N}$-containing $\mathrm{S}$ phase, just as they do not etch nitrides, supporting the hypothesis of the formation of a layer consisting of an unknown nitride. The ability of different etchants to outline the characteristic features of the modified layer microstructure, observable in cross- or tapered sections, can be inferred comparing the micrographs reported in literature, and it was also suggested by Borgioli et al. by comparing the micrographs of nitrided AISI 316L samples etched with glyceregia and glyceregia enriched in glycerol [116] or in $\mathrm{HCl}$ [62]. Thus, the proper etching solutions and conditions should be used to delineate all the microscopy features present in the modified surface layers.

The cross- and tapered section microstructures of an AISI $316 \mathrm{~L}$ sample nitrided at $380{ }^{\circ} \mathrm{C}$ and $340 \mathrm{~Pa}$ for $3 \mathrm{~h}$ are shown in Figure 4. X-ray diffraction patterns of the same sample, also showing the austenite substrate, $\gamma-\mathrm{Fe}$, and the untreated steel, are depicted in Figure 5. The etching clearly delineates two layers, an outer thicker layer, in which slip lines are present, and an inner layer without evident features. The interface with the substrate does not appear as a discrete boundary, such as a high-angle boundary [77]. Even if the formation of a two-layer microstructure has been reported by some authors $[41,57,66,68,70,71,76,94,132,133]$ and it is also apparent in micrographs present in several papers [47,61,64,72,115,134,135], it is often neglected, and the inner layer has been reported as an interface resulting from the steps formed by mechanical grinding and polishing of the metallographic specimens and due to the differences in hardness [47]. The examination of tapered sections, as that reported here in Figure $4 \mathrm{~b}$ or present in literature [64,133], as well as of cross-sections of samples of different austenitic stainless steels $[57,68,70,71]$, indicates that the inner layer is not an artefact but a real feature of the nitrided layers.
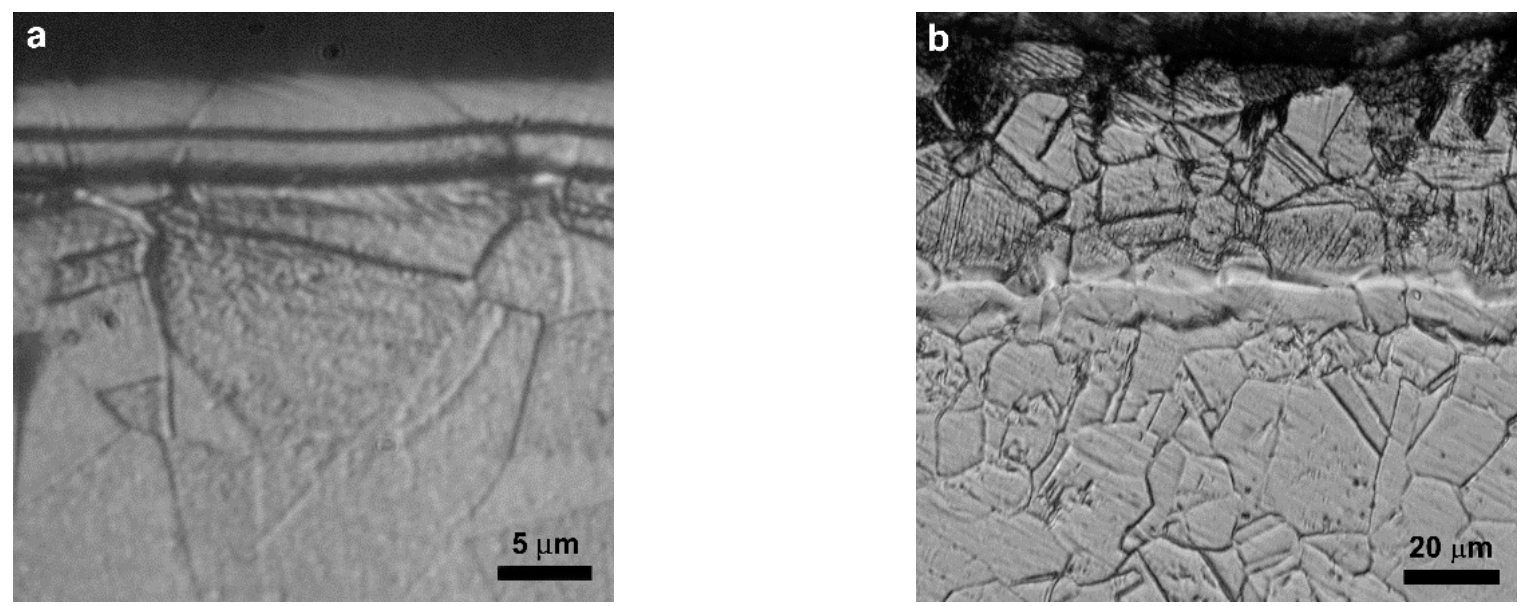

Figure 4. Cross-section (a) and tapered section $\left(\sim 10^{\circ}\right)(\mathbf{b})$ of an AISI 316L sample plasma nitrided at $380{ }^{\circ} \mathrm{C}, 340 \mathrm{~Pa}, 3 \mathrm{~h}$. For further experimental details, see [70]. (Etchant: acetic glyceregia ( $3 \mathrm{~mL}$ $\mathrm{HCl}, 2 \mathrm{~mL} \mathrm{HNO}_{3}, 2 \mathrm{~mL}$ acetic acid, 1 drop of glycerol; in (b) the marker refers to the length in the tapered section)). 


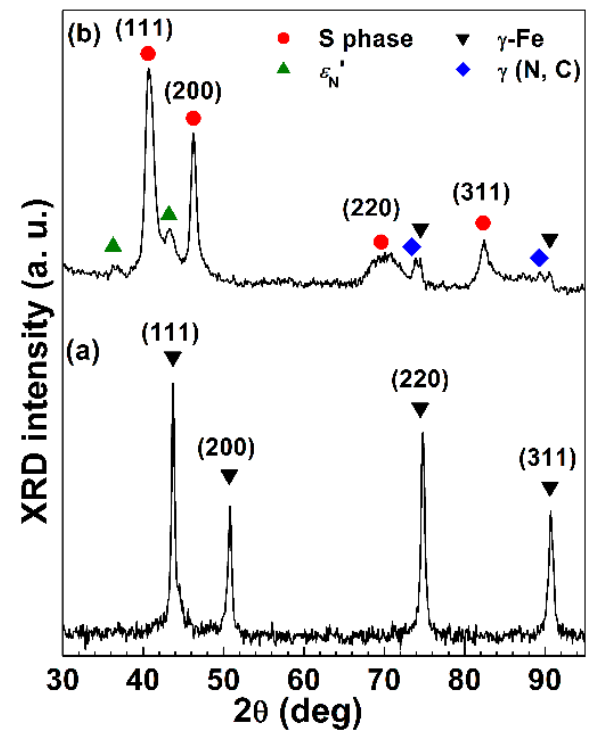

Figure 5. X-ray diffraction patterns of AISI 316L samples: (a) untreated; (b) plasma nitrided at $380{ }^{\circ} \mathrm{C}$, $340 \mathrm{~Pa}, 3 \mathrm{~h}$ (Bragg-Brentano configuration, $\mathrm{Cu} \mathrm{K} \alpha$ radiation). For further experimental details, see [70].

Even if the formed modified layers are fairly homogeneous, grain-to-grain variation in thickness may be observed, owing to different $\mathrm{N}$ diffusion in differently oriented grains [104,124], as also pointed out by Abrasonis et al. [124] when studying ion beam nitriding of single crystals. Etching also allows to outline the grain boundaries, which appear as the continuation of the austenite matrix grain boundaries, and the continuation of the characteristics twins present in the matrix has been observed [116]. Both grain boundaries and twins may show a slight rotation with respect to the substrate, in accordance with the analysis of the surface (see Section 4.1) [126].

In the outer modified layer many lines can be observed. Their number and extension in the substrate depend on nitriding condition and alloy composition [70,71]. These lines are well observable in tapered section, where the complex structure of slip lines and shear bands (here intended as a collective term for planar defects that form during plastic deformation as a result of the overlapping of stacking faults on austenite $\{111\}$ planes $[71,136])$ due to the plastic deformation of the outer part of the modified layer is easily recognizable [71]. In the X-ray diffraction analysis of the nitrided layers, beyond the peaks of the $S$ phase, the presence of additional peaks has been reported $[57,68,70,71,137]$. These peaks have been ascribed to a solid solution of $\mathrm{N}$ in hexagonal close-packed (hcp) martensite, $\varepsilon_{N^{\prime}}$ [137]. The occurrence of this phase has been related to the plastic deformation caused by the formation of nitrided layers $[68,71,137]$. In fact, when plastic deformations occur in austenitic stainless steels, a perfect dislocation may dissociate into two Shockley partials on the $\{111\}$ slip planes, and form wide (intrinsic) stacking faults, in which the $A B C A B C$ stacking, characteristic of a fcc lattice, become an ABAB stacking, characteristic of a hcp structure $[136,138]$. This stacking faulted region may be regarded as a thin, four lattice plane-thick hcp $\varepsilon^{\prime}$ martensite crystal. When regular overlapping of stacking faults on every second $\{111\}$ plane occurs, an $\varepsilon^{\prime}$ martensite plate forms. The $\alpha^{\prime}$ martensite, having a body-centered tetragonal (bct) lattice, may also nucleate at the intersection of $\varepsilon^{\prime}$ martensite laths $[136,138]$. It has been suggested that, when the width of stacking faults diverges, shear bands extend through the austenite grains [136]. The formation of shear bands and $\varepsilon^{\prime}$ martensite is supposed to be favored when the stacking fault energy (SFE) of the steel is low [136]. SFE depends on the chemical composition of the steel [3,139], and is also influenced by solubilized $\mathrm{N}$, which is supposed to decrease SFE further on [140]. As a consequence, while steels like AISI 202, having a low SFE, usually have many shear bands in the modified layers and show the presence of a fairly high content of hcp phase in X-ray diffraction patterns [68,70,71,117], alloys as AISI 316L [57,69-71] and AISI 316 [57] usually have few slip lines observable in the cross-section of the modified layers and hcp $\varepsilon_{\mathrm{N}}{ }^{\prime}$ is 
hardly detectable. On the basis of their study on AISI 304L, high-Mn low-Ni Staballoy AG17 ${ }^{\circledR}$ and high-Ni low-Mn RA $330^{\circledR}$ austenitic stainless steels, triode-plasma nitrided in the range $400-450{ }^{\circ} \mathrm{C}$ for 4 and $20 \mathrm{~h}$, and of literature data, Tao et al. [110] concluded that a correlation exists between localized lattice distortion under $\mathrm{N}$-induced strain and the SFE of the substrate. Strain induced hcp $\varepsilon^{\prime}$ martensite transformation is energetically favorable for alloys with low SFE, as AG1 ${ }^{\circledR}$, while, as SFE increases, twinning deformation tends to be promoted under strain, and the contribute of martensite transformation decreases.

A deeper insight of the characteristics of the modified layers has been obtained by using transmission electron microscopy (TEM) observations. TEM analysis have shown the presence of dislocations, twins, stacking faults, slip bands and lamellar structures ascribable to a hcp phase analogous to the $\varepsilon^{\prime}$ martensite $[35,77,110,114,137]$. Strip-shaped regions, about $3-25 \mathrm{~nm}$ wide [141], nanotwins and bundle structures consisting of a large number of stacking faults [142] have been observed. Selected area electron diffraction (SAED) patterns usually show different features, as those sketched in Figure 6. In the SAED patterns collected in the zones rich of defects a "streaking" of the $<111>$ pattern of the S phase has been observed [35,142-144], and it has been shown to correspond to a high density of stacking faults on the $\{111\}$ planes of $S$ phase [110]. Spots characteristics of twins have also been observed $[141,142,144]$. In the SAED patterns, spots indexed as ascribable to a hcp structure have also been reported [35,110,114,137]. As recalled previously, it has been supposed that hcp stacking, $A B A B$, derives from an arrangement of stacking faults on every second $\{111\}$ austenite plane. The hcp structure is coherent with the matrix and it shows the Shoji-Nishiyama orientation relationship typical of austenite, $\gamma$, to hcp martensite, $\varepsilon^{\prime}$, transformation, $\{111\}_{\gamma} / /\{0001\}_{\varepsilon^{\prime}}$ and $[1 \overline{1} 0]_{\gamma} / /[11 \overline{2} 0]_{\varepsilon^{\prime}}[110,137]$. According to Lei et al. [137] this hcp structure can be regarded as equivalent to $\varepsilon^{\prime}$ martensite produced by the plastic deformations caused by the formation of the modified layers and having larger lattice parameters due to $\mathrm{N}$ solubilization. This hypothesis has been accepted by many authors $[57,68,70,110,114]$, also for explaining the additional peaks present together with $S$ phase in X-ray diffraction patterns, which are ascribable to a hcp structure. However, according to Tong et al. [141], these regions should be regarded as "clustered" stacking faults, instead of nanometric plates of $\mathrm{N}$-rich $\varepsilon_{\mathrm{N}}{ }^{\prime}$ martensite.

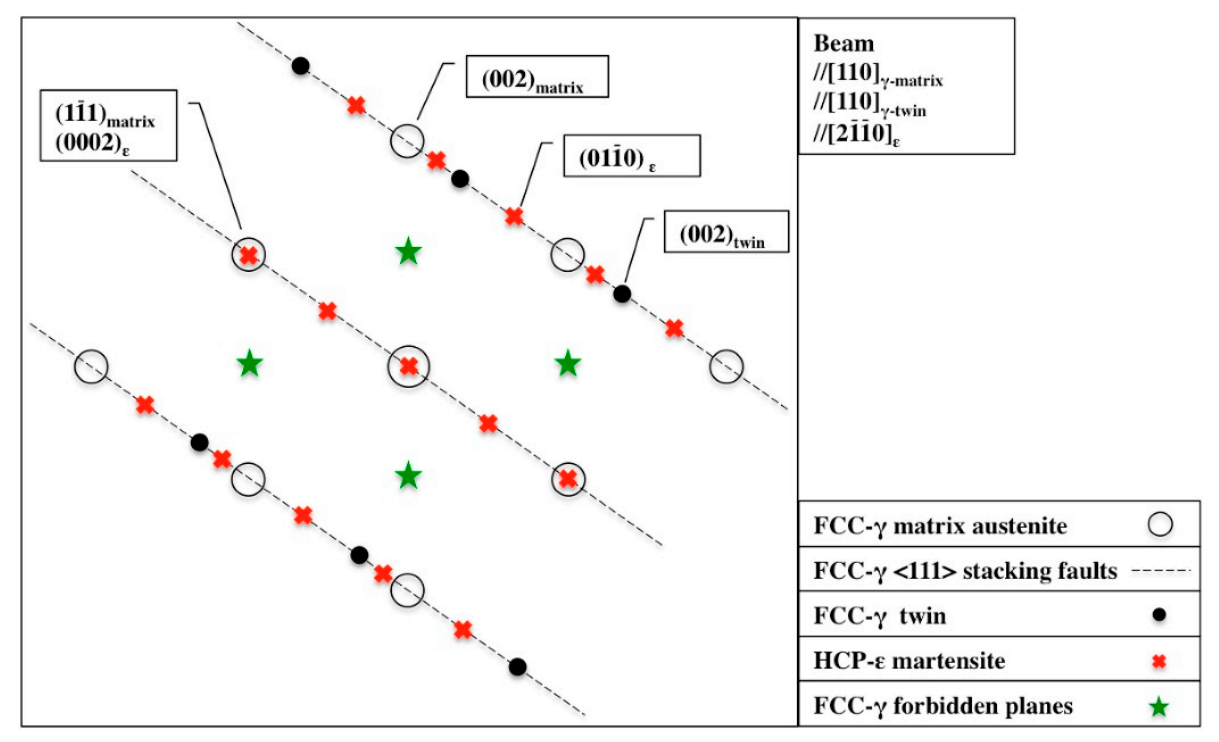

Figure 6. Sketch of the electron diffraction features observable in modified surface layers produced by low temperature nitriding. For further details, see [110]. (Reprinted from Acta Materialia, 164, X. Tao, X. Liu, A. Matthews, A. Leyland, The influence of stacking fault energy on plasticity mechanisms in triode-plasma nitrided austenitic stainless steels: Implications for the structure and stability of nitrogen-expanded austenite, 60-75, Copyright (2019), with permission from Elsevier). 
The SAED patterns of the $S$ phase are characterized by broad diffuse electron diffraction spots [77] and seem to indicate an almost isotropically expanded fcc structure $[77,110]$. However, several authors [35,114,141,142,145] have observed additional weak reflections, which correspond to forbidden reflections of a fcc structure, suggesting a primitive cubic lattice. Stróż and Psoda [142] detected weak forbidden spots of $\{100\}$ type in SAED patterns. Dark field observations highlighted very small regions contributing to the spot. In the high resolution TEM (HRTEM) image of the region, every second (100) lattice plane showed a different contrast, which might be due to a different chemical composition. The authors suggested that the forbidden spots may be caused by a short-range ordering process, and hypothesized the formation of the $\gamma^{\prime}-\mathrm{Fe}_{4} \mathrm{~N}$ phase, with $\mathrm{N}$ at the center of the octahedral site. The presence of $\gamma^{\prime}-\mathrm{Fe}_{4} \mathrm{~N}$ was not detected by X-ray diffraction analysis. Jiang and Meletis [143] analysed intensified plasma assisted nitrided AISI 316 specimens by means of TEM and HRTEM and observed forbidden reflections of the fcc structure, thus concluding that the obtained phase had a simple cubic structure, in which $\mathrm{N}$ atoms occupied only one of the four interstitial octahedral sites, analogous to the $\gamma^{\prime}-\mathrm{Fe}_{4} \mathrm{~N}$ nitride structure. This phase was present over the entire specimen cross-section, and no second phase and/or precipitates were detected. Dark-field image suggested that the phase was formed as a domain structure rather than a precipitate structure. Antiphase domains and antiphase boundaries were observed with HRTEM. The formation of a $\gamma^{\prime}-\mathrm{Fe}_{4} \mathrm{~N}$-like ordered phase was also recently observed by Che et al. [146] in Fe-Cr-Ni austenitic alloys and AISI 304L, subjected to plasma-based low-energy N ion implantation treatment at $380^{\circ} \mathrm{C}$ for $4 \mathrm{~h}$. While the alloys with a $\mathrm{Cr}$ content lower than $12 \mathrm{wt} . \%$ had a clear two-layer structure, consisting of an outer $\gamma^{\prime}-\mathrm{Fe}_{4} \mathrm{~N}$ layer and an inner S-phase layer, the alloys with a $\mathrm{Cr}$ content greater than $12 \mathrm{wt} . \%$ had a featureless modified layer. In this layer X-ray diffraction analysis and TEM showed the presence of an outer region, in which $\gamma^{\prime}-\mathrm{Fe}_{4} \mathrm{~N}$-like long-range ordered phase was present, and an inner zone consisting of interstitially disordered S phase. A long-range ordered structure analogous to $\gamma^{\prime}-\mathrm{Fe}_{4} \mathrm{~N}$ was also supposed to form in AISI 316 foils gas nitrided in order to have a homogeneous $\mathrm{N}$ content of 35.5 at.\% $\left(y_{\mathrm{N}}=0.55\right)$ on the basis of X-ray-diffraction analysis and conversion electron Mössbauer spectroscopy (CEMS) results [147].

The presence of nano-sized clusters can be observed only by TEM, field ion microscopy (FIM) or atom probe tomography (APT). Nano-sized precipitates were observed with FIM by Martinavičius et al. [148] on nitrided layers, which, according to X-ray diffraction analysis, appeared to be constituted by the S phase only. At about 6- $\mu \mathrm{m}$ depth, precipitates of $\sim 10 \mathrm{~nm}$ were observed as being often aligned in a row and on grain boundaries. Deeper in the nitrided layer $(\sim 16 \mu \mathrm{m})$, these precipitates were smaller $(\sim 5 \mathrm{~nm})$ and less abundant, and they tended to maintain their row alignment. A successive APT investigation [149] showed that nanometric $\mathrm{MN}(\mathrm{M}=\mathrm{Cr}, \mathrm{Fe})$ precipitates tend to form preferentially at planar defects. Preferential bonding of $\mathrm{N}$ to $\mathrm{Cr}$ atoms has been observed (see Section 4.3). On the basis of the observation of these short-range ordered Fe-Cr-N clusters Sasidhar and Meka [150] hypothesized that the "colossal" supersaturation implies a spinodal decomposition, which produces the nano-sized precipitates.

When temperature, duration or $\mathrm{N}$ feeding increase, nitride precipitates tend to form, especially at grain boundaries $[17,19,62,116,144]$, and they appear as strongly etched regions in the micrographs. $\mathrm{CrN}$ is usually detected with X-ray diffraction analysis or TEM analysis, and these precipitates are enriched with Cr $[19,62,68,77,116,137,144]$.

Another peculiar feature shown by low temperature nitrided samples is the presence of the thin inner modified layer, which may be hypothesized to be constituted by a solid solution of interstitial atoms $(\mathrm{N}, \mathrm{C})$ in fcc austenite. In X-ray diffraction patterns this phase, indicated as $\gamma(\mathrm{N}, \mathrm{C})$ in Figure $5 b$, can be detected as a fcc phase with the peaks slightly shifted towards lower angles in comparison with those of austenite, and it can be observed in many X-ray diffraction patterns reported in literature $[25,36,68,71]$. The lattice expansion of this phase is fairly low, with a lattice parameter increase of about $0.6 \%$ [68]. Many hypotheses have been suggested to explain the formation of this layer. Some authors have reported an increase of $C$ content in correspondence with this inner layer [76,132,151]. Czerwiec et al. [76] and Michler [132] hypothesized that this C-rich layer formed as 
a consequence of $\mathrm{C}$ contamination due to a sputtering step performed with $\mathrm{Ar}-\mathrm{H}_{2}$ gas mixture before nitriding. However, this layer has also been observed when the sputtering step before plasma nitriding has been carried out with $\mathrm{N}_{2}-\mathrm{H}_{2}$ gas mixtures $[68,70,71]$, which should be efficient in removing $\mathrm{C}$ adsorbed on the surface of samples [76], or using plasma immersion ion implantation [151]. It has been suggested [152] that the insertion of $\mathrm{N}$ atoms, due to nitriding, pushes the free $\mathrm{C}$ atoms head, leading to an accumulation of $\mathrm{C}$ at the end of the $\mathrm{N}$ profile, due to a possible interaction among the interstitial atoms during diffusion. This hypothesis is in accordance with the trapping-detrapping model, according to which each $\mathrm{Cr}$ atom in the stainless steel is associated with a trap site for one interstitial, thus it can arrest diffusing interstitial atoms. Since $\mathrm{Cr}$ has higher affinity for $\mathrm{N}$ than for $\mathrm{C}$, the trap sites near the surface are preferentially filled with $\mathrm{N}$ atoms, while $\mathrm{C}$ atoms diffuse deeper in the bulk to occupy unfilled trap sites. $\mathrm{C}$ atom accumulation at the end of $\mathrm{N}$ profile has also been observed in gas nitrided specimens [59,153], and the maximum measured value increases as the C content in the steel is higher [59]. Williamson et al. [66] hypothesized that the mechanism of formation of two layers is related to the very high residual stress, induced between the S-phase layer and the substrate, so that $\mathrm{N}$ diffusion may increase locally and cause the formation of a sublayer. The double layer microstructure has also been observed on gas nitrided samples [57,94], and it has been related to $\mathrm{N}$ concentration profile, characterized by a steep decrease of concentration followed by a slow fading "tail" [94]. It has been hypothesized that the inner layer corresponds to this part of low N concentration, which is supposed to be due to $\mathrm{N}$ not trapped by $\mathrm{Cr}$ [94].

A double layer microstructure has been obtained with nitrocarburizing treatments, using $\mathrm{N}$ - and C-containing gas mixtures, or by alloying with $\mathrm{C}$ and $\mathrm{N}$ sequentially, both with nitriding followed by carburizing and carburizing followed by nitriding $[42,60,154]$. For this treatment type, the peculiar diffusion profiles of $\mathrm{N}$ and $\mathrm{C}$ have been explained on the basis of trap model [56,155], or on a thermodynamic model with concentration-dependent diffusivity $[56,156]$.

In low temperature carburized samples, only one modified layer is usually observed [42,55,57,72, $129,130,157]$, and, to our knowledge, evidences of an inner distinct layer have not been reported.

\subsection{Atomic Structure and Chemical Composition of the S Phase}

Even if energy dispersive X-ray spectroscopy (EDS) analysis suggests that the distribution of alloy elements in the $S$ phase is homogeneous and it remains the same of the matrix $[71,77,116]$, at the atomic scale the distribution is far -from homogeneous. As recalled previously, $\mathrm{N}$ (or C) atoms occupy the octahedral interstitial sites in the fcc lattice of austenite. For an ideal solid solution, random occupancy should occur for the interstitial sites and for the metal ( $\mathrm{Fe}, \mathrm{Cr}, \mathrm{Ni}, \mathrm{Mo}, \mathrm{Mn}$ ) at the neighboring sites in the fcc lattice. On the contrary, experimental data suggest a different picture.

Using X-ray photoelectron spectroscopy (XPS) analysis many authors agree that the binding energy of N1s is lower than that of free $\mathrm{N}$ atoms $(398.5 \mathrm{eV})$ but it is higher than that in the Cr nitride $(396.7 \mathrm{eV})$ [114,128,158-161]. Values of 397.25 [114], 397.0 [159], 397.1 [160] and 397.2 [128,158] eV have been reported. The binding energies of $\mathrm{Cr}$ have been indicated to be that of metal $\mathrm{Cr}[114,160]$, or the spectrum has been reported to have contribution by both $\mathrm{Cr}-\mathrm{Cr}$ (metal) and $\mathrm{Cr}-\mathrm{N}[158,159,161]$. On the other hand, Fe [114,159,161] and Ni [114] have binding energies characteristic of metal state. The obtained results suggest that a preferential bonding of $\mathrm{N}$ to $\mathrm{Cr}$ atoms is established, but the binding energy is lower than that of $\mathrm{Cr}$ nitrides. The tendency to form $\mathrm{Cr}-\mathrm{N}$ complexes has also been observed in N-containing stainless steel AISI 316LN, subjected to ageing at $850{ }^{\circ} \mathrm{C}$ for up to $25 \mathrm{~h}$ [49]. It has been hypothesized that the high lattice strains induced by $\mathrm{N}$ and the high negative enthalpy of binding $\mathrm{N}$ with $\mathrm{Cr}$ may result in a high driving force for the formation of $\mathrm{Cr}-\mathrm{N}$ clusters. 
Using a combination of global probes (X-ray diffraction, nuclear reaction analysis (NRA), glow-discharge optical emission spectroscopy (GDOES)) and local probes (FIM, CEMS, X-ray absorption near edge structure (XANES) and extended X-ray absorption fine structure (EXAFS) spectroscopies), Martinavičius et al. [148] studied the morphology, phase structure and chemical state of the $S$ phase present at the surface of AISI $304 \mathrm{~L}$ plasma nitrided at $400{ }^{\circ} \mathrm{C}$ for $30 \mathrm{~h}$. CEMS and XANES results suggested that the Fe environment in $\mathrm{S}$ phase was very similar to that of $\gamma^{\prime}-\mathrm{Fe}_{4} \mathrm{~N}$ but with a large disorder. XANES results for $\mathrm{Cr}$ indicated a tendency toward a $\mathrm{CrN}$-like environment, with a $\mathrm{Cr}-\mathrm{N}$ bonding. The $\mathrm{N}$ coordination number was 5.7, very close to the $\mathrm{N}$ coordination number of $\mathrm{CrN}(6)$, and the interatomic distance values suggested that regions enriched in $\mathrm{Cr}$ formed, having a diameter of several atomic spacings. Ni did not seem to form any direct bond with $\mathrm{N}$, even if it had atomic coordination similar to Fe. The results of spectroscopic techniques suggested that there were three times more $\mathrm{N}$ atoms around $\mathrm{Cr}$ than around $\mathrm{Fe}$, while there was almost no $\mathrm{N}$ around $\mathrm{Ni}$. Around $\mathrm{Ni}$ the lattice was depleted in $\mathrm{N}$, but enriched after a distance larger than one metal-metal distance. Thus the authors hypothesized that the nitrided S phase layer was composed of nanometric $\mathrm{CrN}$ precipitates, coherent with the matrix, incorporated in a $\gamma^{\prime}-\mathrm{Fe}_{4} \mathrm{~N}-$ like matrix. The APT study of Martinavičius et al. [149], recalled in the previous section, reported the presence of parallel Cr enriched planes, followed by $\mathrm{Cr}$-depleted ones with a $\sim 4.5 \mathrm{~nm}$ average distance. These planes may result from the gathering of nanometric $\mathrm{CrN}$-like precipitates. In the $\mathrm{Cr}$-depleted region concentrations as low as 10 at. $\%$ were observed, while $\mathrm{N}$ was distributed more homogeneously, maintaining values that were compatible with the presence of $\gamma^{\prime}-\mathrm{Fe}_{4} \mathrm{~N}$-like regions where $\mathrm{Cr}$ is low. Regions with a fairly random $\mathrm{Cr}$ distribution, corresponding to the absence of precipitates, were also observed.

Other EXAFS experiments [162] were performed on AISI 316 foils gas nitrided in order to produce unstressed samples with a constant homogeneous $\mathrm{N}$ content. The obtained results pointed out the preferential $\mathrm{Cr}-\mathrm{N}$ bonding, while neither Fe nor Ni seemed to form any preferential bonding with $\mathrm{N}$. Thus the formation of short-range ordered structures of $\mathrm{Cr}$ and $\mathrm{N}$ have been hypothesized. The $\mathrm{N}$ coordination number was between 3.0 and 4.9. With a concentration ratio of $\mathrm{Cr}$ and $\mathrm{N}$ close to 1:1, each $\mathrm{Cr}$ atom had an average of three neighboring $\mathrm{N}$ atoms after the loose bound $\mathrm{N}$ atoms were withdrawn.

Recently, Tong et al. [163] investigated the short-range ordered structures of the $\mathrm{Fe}-\mathrm{Cr}-\mathrm{N}$ clusters in fcc Fe and stabilization mechanisms of $S$ phase by first principle calculation. According to their analysis, a $\mathrm{Fe}_{6-\mathrm{n}} \mathrm{Cr}_{\mathrm{n}} \mathrm{N}$ octahedral cluster can be considered the unit of clusters. Clusters with more $\mathrm{Cr}$ atoms are energetically favored, and $\mathrm{Cr}$ atoms tend to distribute in pairs at the opposite octahedron vertexes. As $\mathrm{N}$ concentration increases, the clusters may combine into clusters with larger scale, preferring the edge-shaped mode and the preferential locations of $\mathrm{Cr}$ atoms are the shared sites, while $\mathrm{N}$ atoms are on the planes of different magnetic moment. According to their study, the $\mathrm{S}$ phase can be described as fcc Fe dispersively embedded with short-range ordered clusters. No evidence of a $\gamma^{\prime}-\mathrm{Fe}_{4} \mathrm{~N}$-like structure of the $\mathrm{S}$ phase has been found. The $\mathrm{S}$ phase seems to be stabilized by a chemically-driven mechanism by $\mathrm{Cr}$ and $\mathrm{N}$ atoms forming short-range ordered clusters.

The preferential bonding with $\mathrm{Cr}$ atoms has also been observed for $\mathrm{C}$ atoms in carburized samples. The EXAFS analysis of AISI 316 foils, carburized at $420^{\circ} \mathrm{C}$ for $16.25 \mathrm{~h}$, carried out by Oddershede et al. [164], pointed out that for $\mathrm{C}$ atoms a strong affinity with $\mathrm{Cr}$ occurs, so that a short-range ordering is expected.

\subsection{Crystallographic Structure of the S Phase}

As reported early on by Ichii et al. [18], the X-ray diffraction pattern of the S phase shows peaks that are asymmetrically broadened and shifted toward lower angles, in comparison with those of $\mathrm{fcc}$ austenite parent phase. Moreover, if a fcc lattice is assumed for the $\mathrm{S}$ phase as indexing base, the lattice parameter value, $a_{h k l}$, calculated from the $d$-spacing of the (200) plane, is always greater than that calculated from the $d$-spacing of the (111), (220), (311) or (222) planes [42,62,76,134,161,165-167]. Some authors have also suggested that lattice parameters $a_{111}, a_{220}$ and $a_{311}$, are comparable [165], but this experimental result has not been always registered. It has been observed that in a plot of lattice 
parameters $a_{h k l}$ vs. the Nelson-Riley extrapolation function, $\cos \theta \cot \theta$, which usually allows a high precision assessment of the lattice parameter [168], the data do not fall along a straight line, as it should be for an ideal fcc structure, but they have a wider scatter (Figure 7). The trend of the scatter is the same for samples obtained with different techniques, and it was observed for both N- $[42,62,76,134,166]$ and C- $[42,52,157]$ rich S phases, even if the scatter for the C-rich S phase tends to be smaller than that observed for the N-rich one.

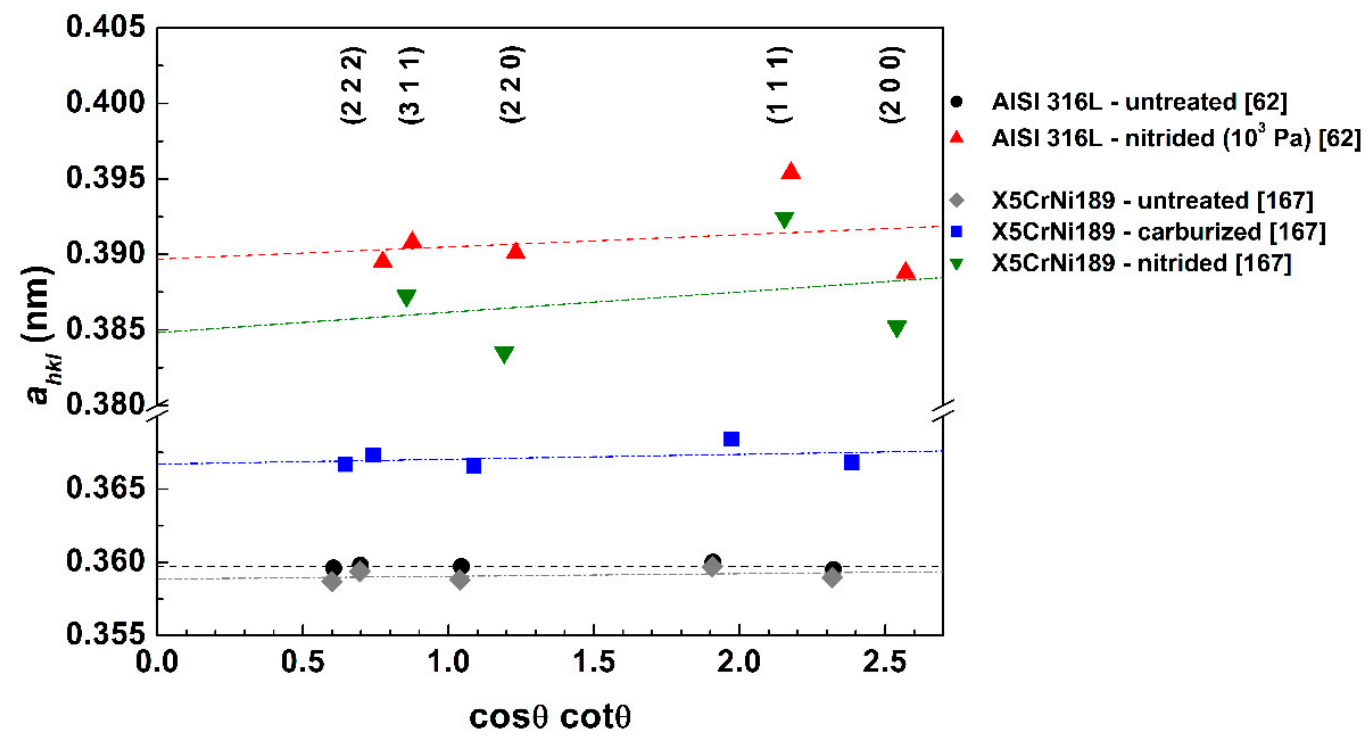

Figure 7. Plot of lattice parameters $a_{h k l}$ vs. $\cos \theta \cot \theta$ for AISI 316L samples, untreated and nitrided at $430{ }^{\circ} \mathrm{C}, 10^{3} \mathrm{~Pa}, 5 \mathrm{~h}$ (ref. [62]) and for $\mathrm{X} 5 \mathrm{CrNi189}$ samples, untreated and subjected to $\mathrm{PI}^{3}$ nitriding and carburizing (ref. [167]).

In order to explain the peculiar features of $S$ phase observed by X-ray diffraction analysis many models have been proposed. It has been hypothesized that the X-ray pattern is due to different phases having different lattice parameters [111,169], that the austenite lattice is distorted resulting in a face-centered tetragonal [23,170,171], or body-centered tetragonal [37] as it occurs in martensite formation. Fewell and Priest [172], using high-order diffractometry data obtained with synchrotron radiation, tested different lattices (mixed fcc lattice, tetragonal, monoclinic, rhombohedral and equal-sided triclinic lattice) without obtaining satisfying results. Mändl and Rauschenbach [173], proposed that the observed differences in $a_{h k l}$ are due to the anisotropy of the elastic modulus of austenitic stainless steel. In fact, as recalled previously, austenite, as a fcc metal, is more rigid in the $<111>$ direction, while it is more elastic compliant in the $<100>$ direction. The elastic anisotropy causes a different shift for the differently oriented grains in presence of a compressive residual stress. However, this model does not correctly reproduce the (222) peak shift, as observed by Sun et al. [134]. The elastic anisotropy model, proposed by Mändl and Rauschenbach [173] is valid for a uniaxial stress applied to a cubic single crystal along the [hkl] direction, and it does not consider the compositional strain resulting from the isotropic introduction of interstitial atoms in the lattice. Czerwiec et al. [42] modified this model considering a planar stress state in the nitrided layer, and they took into account anisotropic elastic and isotropic compositional strains. A stress gradient in the nitrided layer was taken into account by Christiansen and Somers [174].

Another factor, which can cause the anomalous shift of $S$ peaks, is the presence of stacking faults. As recalled in Section 4.2, extended stacking faults have been observed by TEM. A model with a faulted structure has been used by many authors and it allows a good reproducibility of experimental data, at least up to the (222) reflection $[62,134,167,175]$. Using the theoretical analysis developed by Warren [176], the shift of the peaks from their fcc position allows to calculate the lattice parameter and the fault probability $\alpha$. Fault probability in the range $0.09-0.25$ has been obtained $[62,159,167,177]$, 
which corresponds to a faulted plane every about 8 or 4 unfaulted planes, respectively. The Warren's theory hypothesizes a small value of $\alpha$ and it does not consider the finite size of crystallites or the presence of twin faults. Velterop et al. [178] suggested that a weighted summation should be used, but their approach cannot be straightforwardly implemented in a Rietveld fitting procedure. Brink et al. [179] simulated the peak shift by means of Debye scattering equation, taking into account the presence of stacking faults, and they compared the obtained results with synchrotron X-ray diffraction data. The authors optimized the lattice parameter and intrinsic stacking fault probability in order to match the experimental (111) and (200) peak positions of S phase, and found a good reproducibility of the simulated peak shift for (220), (222) and (331) peaks, while a poor one for (311), (400), (420) and, to a lesser extent, (422). It has been hypothesized that the shifts originate from the strong elastic anisotropy of the plastically deformed $S$ phase, since the parent austenite phase has been reported to show $h k l$-dependent elasticity, which becomes non-linear in the elasto-plastic transition [180].

Tong et al. [141], taking into account the "clustered" stacking faults observed by their TEM analysis, simulated the $\mathrm{X}$-ray diffraction pattern of a S-phase layer with similar structures, and found that additional peaks occurred, analogous to those usually ascribed to hcp $\varepsilon_{N}{ }^{\prime}$ martensite.

The combined effect of stacking faults and elastic anisotropy has been proposed by some authors $[134,172,181]$ to explain the anomalous peak shifts. The occurrence of both these effects for the modification of peak position in respect of that of an ideal fcc lattice is reasonable, since both elastic anisotropy and stacking faults have been observed by other experimental techniques and they are not a pure speculation.

Other factors may contribute to the anomalous peak shape and shift. In inhomogeneous samples, as those usually obtained with nitriding, both the $\mathrm{N}$ concentration and compressive residual stress in the nitrided layer change with depth. Taking into account the effects of gradients of composition, stress and stacking faults as a function of depth, Christiansen et al. [181] simulated the X-ray diffraction pattern and found that the composition profile, hypothesized to be described by Hill's equation, was associated with a tail that connected the $S$ phase peak to the corresponding one of austenite and gave it its peculiar asymmetry. Moreover, the influence of residual stress was mostly clearly detected on the (200) peak, due to the elastic anisotropy of austenite, and the influence of a faulting gradient was higher for the (111) peak and smaller for the (200) one.

In order to rule out the effects of different $\mathrm{N}$ composition and the consequent composition-induced macrostresses, $X$-ray diffraction analysis on homogeneous thin foil samples consisting of $S$ phase of uniform composition of N [53] or C [182] has been performed. According to these results, the N-rich $\mathrm{S}$ phase has a fcc lattice and the systematic peak shifts present for each sample can be explained by the presence of stacking faults with a low probability $(\alpha=0.01 \div 0.04$ [53]), probably due to the stress history of the samples [53]. A similar result was found for the C-rich S phase, which was supposed to be unfaulted [182]. The lattice parameter of the S phase increases linearly with the $\mathrm{N}$ content [53] and, similarly, with the C content [182], both expressed as occupancy, $y_{\mathrm{N}, \mathrm{C}}$, according to the following relationships:

$$
\begin{aligned}
& a=0.36395+0.05987 y_{\mathrm{N}}[\mathrm{nm}] \quad \text { for } 0.17<y_{\mathrm{N}}<0.61(14.5<\mathrm{N} \text { content }<38 \text { at.\%) } \quad[31,48,53] \\
& a=0.35965+0.06029 y_{C}[\mathrm{~nm}] \text { for } 0<y_{C}<0.156 \quad(0<\mathrm{C} \text { content }<13.4 \text { at. } \%)
\end{aligned}
$$

The experimental lattice parameters obtained for $\mathrm{N}$ - and C-rich $\mathrm{S}$ phases are related to different composition ranges of interstitial atoms, but their extrapolation points out that $\mathrm{N}$ apparently causes a systematically larger expansion than that of the same $C$ content $[31,48]$. This difference cannot be ascribed to the presence of stacking faults. This fact was also observed for low interstitial content, with $\mathrm{N}$ atoms producing a larger lattice expansion than $\mathrm{C}$ atoms [183]. For a low $\mathrm{N}$ content $(0.3-1.5$ at.\%) the Vegard's constant (i.e. the proportionality constant) for a AISI 304 lattice has been estimated as $8.61 \times 10^{-4} \mathrm{~nm}\left(\right.$ at. \%) ${ }^{-1}$ [183], which corresponds to about $0.085 \mathrm{~nm}$ when the atom content is expressed in occupancy, a slightly larger value than that obtained in [182] for the C-rich S phase. 
Christiansen et al. [48], on the basis of their EXAFS and X-ray diffraction experiments on nitrided or de-nitrided austenitic stainless steel flakes [162,184], hypothesized that this larger expansion has a microstructural origin, i.e., the presence of short-range order in which $\mathrm{N}$ atoms are preferentially bound to $\mathrm{Cr}$ atoms, so that a three-dimensional network (cage structure) in the solid state forms and it is able to induce a dilatation of the austenite lattice and consequently enhance $\mathrm{N}$ solubility.

Recently Wu et al. [104], using X-ray diffraction analysis, evaluated the lattice parameter of S phase for AISI 316L gas nitrided samples as a function of $\mathrm{N}$ content and they observed a discontinuity in the lattice parameter, with a linear increase of lattice constant for low $(<16$ at. $\%)$ and high $(>18$ at. $\%)$ $\mathrm{N}$ content, and an abrupt increase of $0.017 \mathrm{~nm}$ of the lattice parameter from 16 to $18 \mathrm{at} . \%$. The presence of a discontinuity was confirmed analyzing the change in position of $(\overline{44} 4)$ diffraction peak as a function of depth using synchrotron X-ray diffraction. This abrupt change in lattice parameter has been ascribed to the transition from paramagnetic to ferromagnetic behavior of the $S$ phase (see Section 5.7). This discontinuity is similar to that observed comparing the lattice parameters of $\mathrm{N}$ - and C-rich $\mathrm{S}$ phases of homogenous compositions [48], even if in that case only a $0.04 \mathrm{~nm}$ increase occurred at 14.5 at. $\% \mathrm{~N}\left(y_{N}=0.17\right)$, and it has been supposed that it may be related to the change in magnetic properties [147].

\subsection{Residual Stresses in S Phase Layers}

As recalled in Section 4.1, due to the solubilization of interstitial atoms in the austenite lattice beyond the solubility limit, the huge lattice expansion of austenite, modulated in the modified layers, is accommodated by elastic and plastic strains, and it causes high residual compressive stresses at the surface, which are compensated by tensile stresses deeper in the substrate. As pointed out by Somers et al. [46], together with the chemical-induced strains, due to the solubilization of interstitial atoms, the modified layers are also subjected to thermal strains, originated from a gradient in thermal shrinking during cooling. In fact, since the magnetic properties of the modified layers change as a function of the solubilized interstitial atoms (see. Section 5.7), the thermal expansion coefficient also changes and its reduction is expected to occur as a consequence of volume magnetostriction [147]. As a consequence, in the layers where $S$ phase is present, a complicated state of stress occurs. For fairly low interstitial content elastic strains are expected, while for higher amounts of solubilized atoms both elastic and plastic strains are present, and to these concentration-dependent strains thermal strains, due to cooling, are superimposed. Thus, measurement of residual stresses and their profile reconstruction are a very complex task.

Using X-ray microbeam diffraction and the $\sin ^{2}(\psi)$ method, Grigull and Parascandola [185] evaluated these residual compressive stresses in the range-2-3 GPa, while values of -1.7 up to $-3 \mathrm{GPa}$ were obtained by Stinville et al. [122] using the stress differential technique.

In the recent paper of Somers et al. [46], different X-ray diffraction strategies to measure and reconstruct residual stress profiles using the $\sin ^{2}(\psi)$ method were reported. With this technique, by repeating the measure of the lattice spacing for a family of lattice planes $\{h k l\}$ for different values of the tilt angle $\psi$ at different depths, it is possible to calculate the stress-depth profile and the lattice parameter profile. The choice of the proper $\{h k l\}$ lattice planes is very important, in order to avoid erroneous results. For example, choosing the $\{200\}$ planes causes an overestimation of residual stress value in the $\mathrm{N}$-rich $\mathrm{S}$ phase, owing to the large peak shift and the change of elastic constants in the deformed austenite [46]. Moreover, corrections for the presence of ghost stresses, originating from the variation of the depth explored by the X-ray beam as the tilt angle $\psi$ changes, and eventual stress relaxation, originating from sublayer removal, must be taken into account. Residual stress and strain-free lattice profiles have been calculated using grazing-incidence $X$-ray diffraction with constant incident angle, in order to limit the ghost stress effects [186], using grazing incidence X-ray diffraction combining various incidence angles, in order to have a constant information depth [187], removing successive sublayers with electrochemical polishing and using a symmetric $\mathrm{X}$-ray diffraction configuration [188], and using energy dispersive synchrotron X-ray diffraction analysis with the 
scattering vector method, in order to perform a nondestructive analysis [189]. In the surface layers compressive stress values as high as $-4.6 \mathrm{GPa}\left(\mathrm{T}=430{ }^{\circ} \mathrm{C}, \mathrm{t}=20 \mathrm{~h}\right)$ [186], $-5 \mathrm{GPa}\left(\mathrm{T}=440{ }^{\circ} \mathrm{C}\right.$, $\mathrm{t}=16 \mathrm{~h})$ [187] and $-5.8 \mathrm{GPa}\left(\mathrm{T}=440{ }^{\circ} \mathrm{C}, \mathrm{t}=14 \mathrm{~h}\right)$ [189] for nitrided AISI 316 samples, and $-1.6 \mathrm{GPa}$ $\left(\mathrm{T}=520{ }^{\circ} \mathrm{C}, \mathrm{t}=2 \mathrm{~h}, 10 \% \mathrm{CO}\right),-2.2 \mathrm{GPa}\left(\mathrm{T}=515^{\circ} \mathrm{C}, \mathrm{t}=2 \mathrm{~h}, 20 \% \mathrm{CO}\right)$ and $-2.7 \mathrm{GPa}\left(\mathrm{T}=520{ }^{\circ} \mathrm{C}\right.$, $\mathrm{t}=2.5 \mathrm{~h}, 90 \% \mathrm{CO}$ ) [188] for carburized AISI 316 samples have been obtained.

Comparison of the changes of evaluated strain-free lattice values, which are related to the $\mathrm{N}$ content, and residual stresses as a function of depth suggested that the elastically accommodated strain is related with the composition [186], so that the elastic stresses in S phase layer can be modified by modifying the composition profile [46]. An attempt to change N profile was made by Fernandes et al. [187] removing the $\mathrm{N}$ atoms present in a S-phase layer with a de-nitriding treatment in pure hydrogen, and this caused both a substantial change of $\mathrm{N}$ profile, with a wide plateau corresponding to a $\mathrm{N}$ content of about 15.2 at. $\%\left(y_{\mathrm{N}}=0.18\right)$, and a reduction of the compressive stresses, from $-5 \mathrm{GPa}$ in the nitrided condition to $-100 \mathrm{MPa}$ for the de-nitrided condition. Performing a series of nitriding and de-nitriding experiments, in order to obtain samples with a range of $\mathrm{N}$ content, and determining the residual stress of the samples close to the surface allowed to obtain a relation between residual stress and $\mathrm{N}$ content [46].

\section{Properties of S Phase Layers}

\subsection{Elastic Properties and Toughness}

As recalled previously, the elastic modulus of fcc austenite lattice is anisotropic, with the $<111>$ direction more rigid and $<001>$ more compliant. Investigations based on nanoindentation tomography [190] have shown that for the $S$ phase this behavior is reversed, in comparison with that of untreated stainless steel, with the maximum elastic modulus for $<001>$-oriented grains, of $\sim 260 \mathrm{GPa}$ at 5 - $\mu \mathrm{m}$ depth, and the lowest ( $225 \mathrm{GPa}$ at 5- $\mu \mathrm{m}$ depth) for the $<111>$-oriented grains. As the measure was repeated at increasing depths, the elastic modulus decreased, and when the substrate was reached the anisotropy was reversed, with the lowest value for the $<001>$-oriented grains. The observed trend suggests that the trend of elastic modulus profile is related to $\mathrm{N}$ concentration.

Elastic modulus, as derived from the linear portion of the stress-strain curve for AISI 316 foils carburized in order to have a uniform $C$ content, was observed to increase as the $C$ content was higher reaching $244 \mathrm{GPa}$, significantly higher than that of the untreated steel samples, in the range 140-170 GPa depending on thickness of the foils [191].

Tensile tests performed by Thaiwatthana et al. [192] on AISI 316 samples plasma nitrided $\left(400{ }^{\circ} \mathrm{C}\right.$, $3 \mathrm{~h}$ ) or carburized $\left(460^{\circ} \mathrm{C}, 5 \mathrm{~h}\right)$ showed that both nitriding and carburizing increase the yield strength, in comparison with that of untreated steel. Moreover, while the elongation at rupture of the carburized sample was comparable to that of untreated AISI 316, it was much smaller for the nitrided samples, suggesting that toughness of nitrided samples is lower than that of carburized ones. These results about the toughness of the modified layers are in accordance with the studies of Stinville et al. [193], who observed a quasi-brittle mechanical behavior of the nitrided layer of AISI 316L using SEM in situ tensile tests, and by Michal et al. [194], who observed only a modest attenuation of ductility but not a serious embrittlement for carburized AISI 316L samples tested with tensile tests.

\subsection{Hardness}

Low temperature treated austenitic stainless steels have shown a marked surface hardness increase, which depends on the treatment conditions. As the interstitial content of the $S$ phase increases and the modified layers are thicker, higher surface microhardness values are detected. Surface microhardness values as high as $1450 \mathrm{HK}_{0.1}$ [38] have been detected for nitrided specimens. However, values up to $1600 \mathrm{HV}$ have also been reported [17,60,62,85], due to either the presence of $\mathrm{Cr}$ nitrides or the use of small indenter load. For carburized samples, values as high as $1000 \mathrm{HV}$ has been observed [39], and, for low indenter loads, values up to about $1100 \mathrm{HV}$ have been reported [60]. 
Microhardness profiles tend to reflect the average concentration profiles of interstitial atoms, as depicted in Figure 8, so that high hardness values with a steep decrease towards matrix values have been observed for nitriding $[45,57,58,60,192]$, lower hardness values and a smoother profile have been registered for caburizing $[57,58,60,192,194]$, and high values with a gradual change towards matrix values have been observed for nitrocarburized samples $[57,58,60]$, suggesting that solid solution strengthening due to interstitial atom solubilization has a primary role. However, other factors may contribute to the hardness enhancement: work hardening due to the local plastic deformations induced by the formation of $S$ phase, residual stresses, the formation of hcp martensite-like phase and the possible formation of nanometric-sized ordered structures [148].

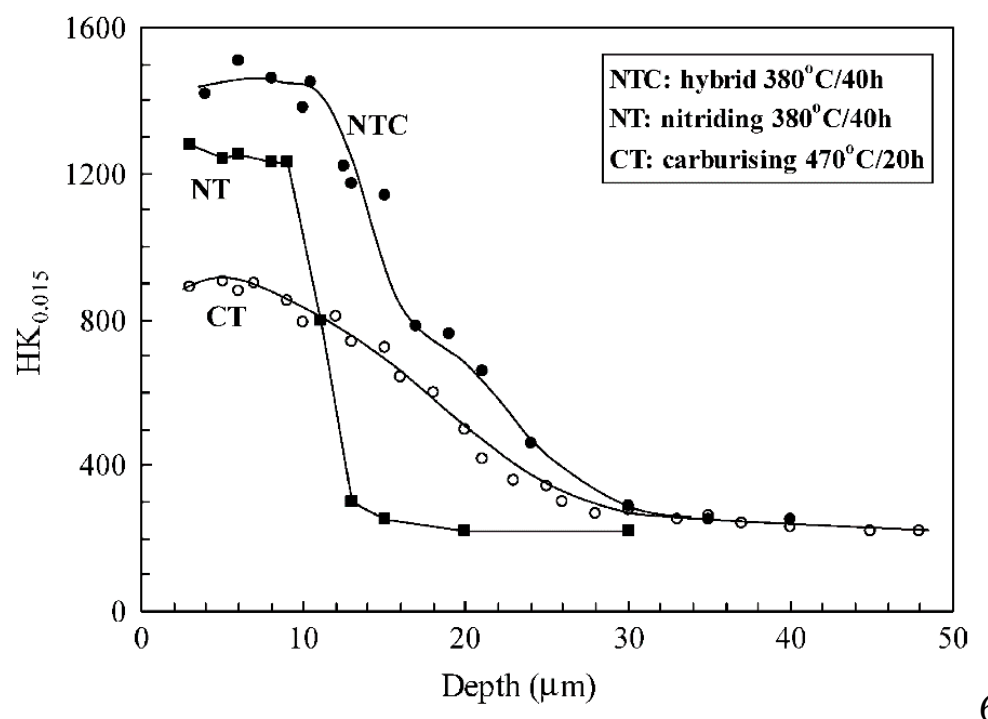

Figure 8. Microhardness profiles of AISI 321 samples plasma nitrided $\left(380^{\circ} \mathrm{C}, 40 \mathrm{~h}\right)$, carburized $\left(470{ }^{\circ} \mathrm{C}\right.$, $20 \mathrm{~h}$ ) and nitrocarburized (NTC hybrid process) $\left(380^{\circ} \mathrm{C}, 40 \mathrm{~h}\right.$ ). For further details, see [60]. (Reprinted from Materials Science and Engineering A, 404, Y. Sun, Hybrid plasma surface alloying of austenitic stainless steels with nitrogen and carbon, 124-129, Copyright (2005), with permission from Elsevier).

Tromas et al. [190] observed a grain-orientation dependence and reversion in comparison with untreated austenitic stainless steel, not only for the elastic modulus but also for hardness. By using nanoindentation tomography on AISI 316L nitrided samples, they reported that, at a 5- $\mu \mathrm{m}$ depth, the highest hardness values ( 18 GPa) were measured for $<001>$ grains and the lowest ( 14 GPa) for the $<111>$ grains, while for the untreated alloy the $<001>$ had the lowest hardness ( $2 \mathrm{GPa})$. As increasing depths were tested, the hardness values decreased and at the matrix the hardness anisotropy of untreated AISI 316L was restored.

Fernandes et al. [187] performed a de-nitriding treatment in pure hydrogen of nitrided AISI 316 samples having a $\sim 15-\mu \mathrm{m}$ thick modified layer consisting of $S$ phase, and obtained a significant change in N profile, with a decrease of the $\mathrm{N}$ content from $\sim 28.5$ to 15.2 at.\% ( $y_{\mathrm{N}}$ from 0.4 to about 0.18 ) in the first $12 \mu \mathrm{m}$ of the nitrided layer. As a consequence, a marked decrease of elastic residual stresses was registered, while the hardness profile was only slightly changed, suggesting that the observed hardness was due to a combination of remaining solubilized $\mathrm{N}$ atoms and plastic deformation introduced by the formation of the layer.

\subsection{Tribological Properties}

The formation of hardened surface layers, due to low temperature treatments, allows to increase the poor tribological properties of austenitic stainless steels. Several studies have elucidated the wear behavior of nitrided $[17,58,195]$, carburized $[17,58,196]$ and nitrocarburized [58] austenitic stainless steels in different test configurations and in dry or lubricated conditions. Pin-on-disk tests were carried 
out on AISI 316 samples, plasma nitrided at temperatures in the range $450-550{ }^{\circ} \mathrm{C}$, by using different stationary sliders (alumina and bearing steel balls) and loads (10-50 N) in dry conditions or in presence of a corrosive solution $\left(10 \% \mathrm{HCl}+5 \% \mathrm{HNO}_{3}+85 \% \mathrm{H}_{2} \mathrm{O}\right)$ and they showed that the wear of both the counterparts depended on the tribosystem, and that for the nitrided samples a significant reduction of wear loss occurred, in comparison with untreated samples [195]. In dry sliding conditions, when the bearing steel was used as counterpart, the untreated steel suffered a severe adhesive wear, with plastic deformations in the subsurface layers. Nitrided samples were subjected to a mild wear, due to oxidative wear, without plastic deformation in the subsurface layers, and their wear volume was more than two orders of magnitude lower than that of the untreated alloy; the samples nitrided at $500{ }^{\circ} \mathrm{C}$, having a modified layer in which a moderate amount of $\mathrm{CrN}$ was present, had the lowest wear volume. When an alumina ball was used as counterpart, the decrease of wear volume for the nitrided samples was smaller than using a steel ball, and the specimens nitrided at $450{ }^{\circ} \mathrm{C}$, having the nitrided layer consisting mainly of the $S$ phase, had the smallest wear volume. When wear tests were performed in presence of corrosive media, the samples nitrided at lower temperature $\left(450{ }^{\circ} \mathrm{C}\right) \mathrm{had}$ the smallest wear volume, due to the favorable combination of high wear and corrosion resistance. When AISI 316 samples were subjected to DC plasma nitriding or active screen plasma nitriding and were tested in a pin-on-disc configuration with a WC/Co ball as counterpart, comparable results were found for both the nitrided sample types, with a comparable wear mechanism (oxidation wear and micro-abrasion) and a wear resistance more than two order of magnitude higher than that of untreated steel [80]. The obtained results were similar to those obtained using a bearing steel as counterpart [195]. The importance of the materials constituting the tribosystem in influencing the wear resistance was put in light by Ceschini et al. [196], who studied the influence of countermaterial on the sliding wear behavior of low temperature carburized AISI 316L in block-on-ring configuration. It was reported that the presence of carburized modified surface layers allowed a significant reduction of the wear rate, while it was not able to reduce the coefficient of friction.

The change in wear mechanism from a sever adhesive wear for untreated steels to an oxidative-mild wear for treated steels has been assessed by many authors, and, as expected, as the hardness and thickness of the modified surface layers increase, wear loss decreases both in dry [63,197,198] and in wet $[119,199]$ conditions. Wear maps for low temperature carburized AISI 316L austenitic stainless steel against alumina in sliding conditions were obtained by $\mathrm{O}^{\prime}$ Donnel et al. [200] using pin-on-disc tests, and they show that for carburized samples wear volume is reduced of about an order of magnitude for loads up to $40 \mathrm{~N}$ and velocity in the range $0.1-0.6 \mathrm{~m} \mathrm{~s}^{-1}$, in comparison with the untreated steel, with a transition from oxidative to mild wear.

Rolling-sliding tests (10\% sliding), carried out with an Amsler wear testing machine in dry conditions using the same sample type as counterpart, have shown that the nitrided samples had a low wear rate as long as the modified layer was not broken, i.e., with low applied load (490 N) [201]. As the applied load increased, the nitrided layer might break, and plastic deformation phenomena were observed in the subsurface layers; the wear rate increased, but tended to remain smaller than that of untreated samples. These results are in accordance with the study of Sun and Bell [202], who tested carburized samples in oil lubricated rolling-sliding conditions (10\% sliding) with a load of $1000 \mathrm{~N}$. Thick $(40 \mu \mathrm{m})$ carburized layers allowed an improvement of wear resistance, while thinner layers had a reduced wear resistance, due to the high Hertzian stress, which had the maximum below the modified layer, thus causing subsurface deformation and rupture of the thin and hard carburized layer.

Studies have also been performed with the aim of comparing the wear resistance of different low temperature treatments. According to Bell [17], when nitrided and carburized (both $415^{\circ} \mathrm{C}$, $12 \mathrm{~h}$ ) AISI 316 samples were tested in pin-on-disk configuration against a WC/Co ball, a larger wear reduction was observed for the nitrided samples, in comparison with carburized ones. On the contrary, 
pin-on-disk tests performed on plasma nitrided, carburized and nitrocarburized AISI 316 specimens with a WC-Co ball as a counterpart and load of $10 \mathrm{~N}$ hashowed a marked reduction of the weight loss, in comparison with the untreated steel, but a better performance of nitrocarburized and carburized samples was observed if compared to that of the nitrided samples [58]. A similar result was obtained by Thaiwattahana et al. [192], who found a slightly lower wear volume for carburized samples, in comparison with nitrided ones, testing them in pin-on-disc configuration, while for abrasive resistance, assessed with ball crater test, a lower wear was observed on the harder nitrided samples, if compared to that of carburized ones. The same behavior was also observed by Duarte et al. [203], who found that, when tested against WC/Co ball in ball-on-disk configuration, triode plasma nitrided $\left(450^{\circ} \mathrm{C}, 5 \mathrm{~h}\right)$ AISI $316 \mathrm{~L}$ specimens had a higher wear volume than carburized $\left(475^{\circ} \mathrm{C}, 3 \mathrm{~h}\right)$ samples. Even if the nitrided samples were harder than carburized ones (12.5 and $7 \mathrm{GPa}$, respectively), the thickness of the hardened layer was smaller ( $\sim 5$ and $30 \mu \mathrm{m}$, respectively), so the better performance of carburized samples may be ascribed to the lower hardness gradient, which allowed a better load-bearing capacity. Samples treated with carburizing $\left(475^{\circ} \mathrm{C}, 3 \mathrm{~h}\right)$ and then nitriding $\left(450^{\circ} \mathrm{C}, 5 \mathrm{~h}\right)$ had a hardened layer $\sim 35-\mu \mathrm{m}$ thick, with a gradual decrease of hardness from about $11 \mathrm{GPa}$ to matrix values (3.6 GPa), and they showed the lowest wear volume. It has been supposed that the outer harder $\mathrm{N}$-rich $\mathrm{S}$ phase hinders plastic deformation, while the inner $\mathrm{C}$-rich $\mathrm{S}$ phase allows a better stress distribution and load bearing capacity. The influence of coupling load on the wear behavior of low temperature treated samples was put in light by Blawert et al. [167]: $\mathrm{PI}^{3}$ nitrided X5CrNi189 specimens were found to have lower wear loss when tested with 5 and $10 \mathrm{~N}$ loads in pin-on-disc conditions, in comparison with carburized samples, but when the load was increased up to $20 \mathrm{~N}$ carburized samples had a better performance.

\subsection{Fatigue Properties}

The enhancement of surface hardness and the formation of high residual compressive stresses make the low temperature treatments suitable processes to increase the fatigue resistance of austenitic stainless steels. Thaiwatthana et al. [192] found that both low temperature plasma nitrided $\left(400{ }^{\circ} \mathrm{C}\right.$, $15 \mathrm{~h})$ and carburized $\left(415^{\circ} \mathrm{C}, 12 \mathrm{~h}\right)$ AISI 316 specimens had an improved fatigue strength and limit, in comparison with those of the untreated alloy. Fatigue limit was improved of more than $25 \%$. It has been observed that the carburized samples have a higher fatigue limit than nitrided specimens, since the nitrided layers are harder but more brittle that carburized ones. When fretting fatigue was assessed, AISI 316 did not show any fatigue limit, while the treated samples had a fatigue limit, that was slightly higher for nitrided specimens. As also observed by Bell [17], for low cycle fatigue (LCF) the curve of fretting fatigue of nitrided samples was comparable to that of plain fatigue of untreated steel, which was higher than that of fretting fatigue for the same specimen type, so that it may be hypothesized that the fretting effect was counteracted by the harder nitrided layer. The fatigue strength increases as the modified surface layers are thicker and harder, as observed by Hoshiyama et al. [198], who tested active screen plasma nitrided AISI 304 samples, treated at $400{ }^{\circ} \mathrm{C}$ for different durations $(2-8 \mathrm{~h})$, with bending fatigue tests. The fatigue strength tended to reach a value of $449 \mathrm{MPa}$ for treatment durations longer than $4 \mathrm{~h}$, while for LCF the measured strength value increased as the treatment duration was longer. Stinville et al. [122] investigated the LCF behavior of AISI 316L samples, plasma nitrided at $400{ }^{\circ} \mathrm{C}$ for durations ranging from $16 \mathrm{~min}$ up to $160 \mathrm{~h}$, by performing cyclic deformation tests in a symmetrical uniaxial push-pull mode in plastic strain control mode; the tests also allowed to evaluate the compressive residual stresses of the nitrided layers. A better performance was observed for the nitrided samples, in comparison with untreated ones, but the number of cycle to failure was related to the treatment duration. The longest fatigue life $\left(5.5 \times 10^{4}\right.$ cycles $)$ was observed for a 3-h duration, which corresponded to the maximum residual compressive stress. For durations longer 
than about $33 \mathrm{~h}$ no improvement of fatigue life was observed, and this behavior was related to the surface damage due to the nitriding treatment, which can cause spalling of some grains and cracking. However, no relaxation of residual stress occurred all along the fatigue life, and values ranging from $-3 \mathrm{GPa}$ (nitriding duration: $3 \mathrm{~h}$ ) to $-1.7 \mathrm{GPa}$ (nitriding duration: $>20 \mathrm{~h}$ ) were registered. Rotating bending fatigue tests of carburized AISI 316L specimens [204] showed that, at $10^{7}$ cycles, fatigue strength reached $521 \mathrm{MPa}$, increasing by more than $40 \%$ compared to that of the untreated steel (366 MPa), and that with air cooling of the carburized samples during the tests a further enhancement of fatigue strength up to $624 \mathrm{MPa}$ could be obtained. Nucleation of fatigue cracks in the untreated specimens occurred at the surface, while for carburized samples occurred near the boundary between the carburized layer and the substrate, regardless of the applied stress level. With tension-compression fatigue tests [205], carried out on gas carburized $\left(470^{\circ} \mathrm{C}, 30 \mathrm{~h}\right)$ AISI $316 \mathrm{~L}$ specimens, the fatigue strength was increased up to $275 \mathrm{MPa}$ for carburized specimens, a $22 \%$ improvement in comparison with the untreated alloy, which showed an endurance limit of $225 \mathrm{MPa}$. Crack initiation sites depended on the applied stresses. For applied stresses $\geq 300 \mathrm{MPa}$, SEM analysis showed that they were at the surface, as detected for untreated samples, and cracks were present along grain boundaries and slip bands in the outer 10- $\mu \mathrm{m}$ thick region of the carburized layer, while for applied stresses lower than $300 \mathrm{MPa}$ fatigue cracks initiated away from the surface at the inclusions, which acted as stress concentrators. A relaxation of the residual stresses in the first $10 \mu \mathrm{m}$ of the modified layer was observed, regardless of the applied stress level.

Low temperature treatments also allow to increase corrosion-fatigue resistance, due to the improved corrosion resistance. Wang et al. [206] tested plasma based low-energy $\mathrm{N}$ ion implanted $\left(400^{\circ} \mathrm{C}, 4 \mathrm{~h}\right) \mathrm{AISI} 304 \mathrm{~L}$ with push-pull fatigue experiments in a borate buffer solution at $\mathrm{pH} 8.4$, and they found that corrosion-fatigue strength was about $230 \mathrm{MPa}$, significantly higher than that of untreated steel (180 MPa). Crack initiation occurred at the interface between the nitrided layer and the matrix, instead of at the surface, as for the untreated alloy.

\subsection{Corrosion Behavior}

\subsubsection{Corrosion Behavior in Chloride Containing Solutions}

In presence of chloride-ion containing solutions austenitic stainless steels may be subjected to localized corrosion phenomena, as pitting or crevice. $\mathrm{N}$ alloying is known to have a beneficial effect when localized corrosion phenomena may occur, promoting passivity, widening the passive range, enhancing the resistance to intergranular corrosion and improving stress corrosion cracking in some media $[3,11-13,207]$. The $\mathrm{N}$ protection mechanism is not completely clear, and different theories have been proposed. The main ones are the following.

- During the early stages of corrosion, $\mathrm{N}$ atoms are released and they may react with $\mathrm{H}^{+}$forming ammonium ions, $\mathrm{NH}_{4}{ }^{+}$, that locally can increase the $\mathrm{pH}$ where pits or crevices are forming, thus promoting repassivation [11,207-209]. $\mathrm{NH}_{4}{ }^{+}$ions may also form nitrates, which inhibit corrosion [209], or they may react with free chlorine in chlorinated water, forming less oxidizing species [210], or they may produce a passive ammonium sulfate layer in sulfate solution [211].

- During passivation, at the film/substrate interface a $\mathrm{N}$ enrichment may occur, so that anion attack is prevented [208,212]. An incorporation of $\mathrm{N}$ and $\mathrm{NH}_{4}{ }^{+}$ions in the passive film has been observed [212].

- Negatively-charged $\mathrm{N}$ may accumulate at the passive layer and may have a repulsive action towards $\mathrm{Cl}^{-}$, so that a faster repassivation may be promoted $[213,214]$. 
For low temperature nitrided austenitic stainless steels, it has been hypothesized that, due to the formation of the N-rich $\mathrm{S}$ phase, the enhancement of corrosion resistance may be due to mechanisms analogous to those suggested for N-containing austenitic stainless steels [47,135,215]. Zhu and Lei [215] studied the corrosion resistance of AISI $1 \mathrm{Cr} 18 \mathrm{Ni}$ Ti, subjected to plasma source ion nitriding at $380{ }^{\circ} \mathrm{C}$ for $4 \mathrm{~h}$, in $3 \% \mathrm{NaCl}$ solutions with $\mathrm{pH}$ ranging from 0.4 to 13 . By means of cyclic polarization tests the authors showed that the formation of $S$ phase extends the immunity and perfect passivity zones and reduces the imperfect passivity and pitting zones, in comparison with the untreated alloy. For pH 0.4-3 a change from general corrosion-imperfect passivity-pitting corrosion phenomena was observed for both untreated and nitrided samples, even if the pitting potential of the nitrided specimens was higher than that of the untreated alloy. For $\mathrm{pH} 4-13$ no pitting corrosion was detected for nitrided samples, while for the untreated steel the typical active-passive transition occurred. Above $\mathrm{pH} 11$ both sample types were not subjected to pitting corrosion. These results suggest that the neutralizing effect of $\mathrm{NH}_{4}{ }^{+}$ions in acidic pits is significant only above a certain range of $\mathrm{pH}$. The role of $\mathrm{N}$ in locally increasing $\mathrm{pH}$ was assessed by Flis-Kabulska et al. [135], who studied the electrochemical behavior of AISI 316L plasma nitrided at $415^{\circ} \mathrm{C}, 500 \mathrm{~Pa}$ for $15 \mathrm{~h}$ in solutions of $0.1 \mathrm{M} \mathrm{Na}_{2} \mathrm{SO}_{4}+0.4 \mathrm{M} \mathrm{NaCl}$ acidified down to $\mathrm{pH}$ 2.4. By carrying out in situ measurements, the authors observed an increase of $\mathrm{pH}$ at the surface of the nitrided samples in the active potential region, and they ascribed this alkalinization to the formation of $\mathrm{NH}_{4}{ }^{+}$ions. They hypothesized that the increase of corrosion resistance is due to a more effective repassivation of incipient pits rather than a slow nucleation.

When $\mathrm{NaCl}$ water solutions are used as probe solution, low temperature nitrided austenitic stainless steels samples show an improved corrosion resistance, as long as significant amounts of nitrides are not present in the nitrided layer $[45,62,70,71,81,216]$. The protectiveness of S-phase layer and its ability in hindering and delaying the occurrence of corrosion phenomena increases as the $\mathrm{N}$ content and the thickness of the layer increases, i.e., as the $\mathrm{N}$ feeding, treatment temperature and duration are chosen in order to obtain a N-rich, nitride-free and thick modified surface layer $[38,62,68,70,71,116]$. The polarization curves of modified surface layers, consisting mainly of the $S$ phase, usually have higher corrosion and pitting potential values and lower anodic current in the passive branch, in comparison with those of untreated samples [60,63,70,81,118], as shown in Figure 9a. The comparison of the corrosion behavior of different austenitic stainless steels (AISI 316L, AISI 202 and Ni-free P558), subjected to plasma nitriding at 360 and $380^{\circ} \mathrm{C}$ at $340 \mathrm{~Pa}$ for $3 \mathrm{~h}$, has suggested that the nobler corrosion potential and lower anodic passive currents are mainly influenced by solubilized $\mathrm{N}$, while for the pitting potential an important role may also be played by alloy elements [70]. In particular, Mo, in synergy with $\mathrm{N}$, tends to improve corrosion resistance further on, so that Mo-containing austenitic stainless steels usually show an improved corrosion resistance after nitriding $[70,71,217]$. The effect of alloy elements in influencing corrosion potential values has been registered by some authors [217,218]. The ability of low temperature nitriding in repassivating, after the occurrence of significant localized corrosion phenomena, is not obvious. When the cyclic potentiodynamic method has been used for measure the repassivation, or protection, potential, a repassivating potential has not always been measured [215,219], or it has been lower than that of the untreated alloy [219,220]. The use of galvanostatic tests has allowed to put in light that, after the occurrence of a localized corrosion phenomena, potential values below which corrosion does not occur are higher than corrosion potential, suggesting that repassivation phenomena may occur when the depth of pits or crevices is not too high [70]. These different results may be ascribed to the used test techniques, that influence the system response owing to the different damage extent [221]. The enhancement of corrosion resistance for the nitrided samples can be also observed by using electrochemical impedance spectroscopy (EIS) analysis. As shown in Figure 9b, nitrided samples usually have higher impedance values and the semicircle in their Nyquist plot is wider [70,222-225], suggesting a better resistance to general corrosion [226]. 
The impedance data of untreated and nitrided austenitic stainless steels are usually modelled using a Randles circuit with only one time constant [160,223,225,227], or with two time constants hierarchically connected or in series [70,160,222,225,227], depending on specimen characteristics and test solution. When two time constants are used, one is connected to the charging/discharging processes occurring at the electrode/electrolyte interface, the other to the charge transfer and mass transport processes in the oxide phase, but their attribution to the high or low frequency time constant is not univocal $[70,222,227]$.
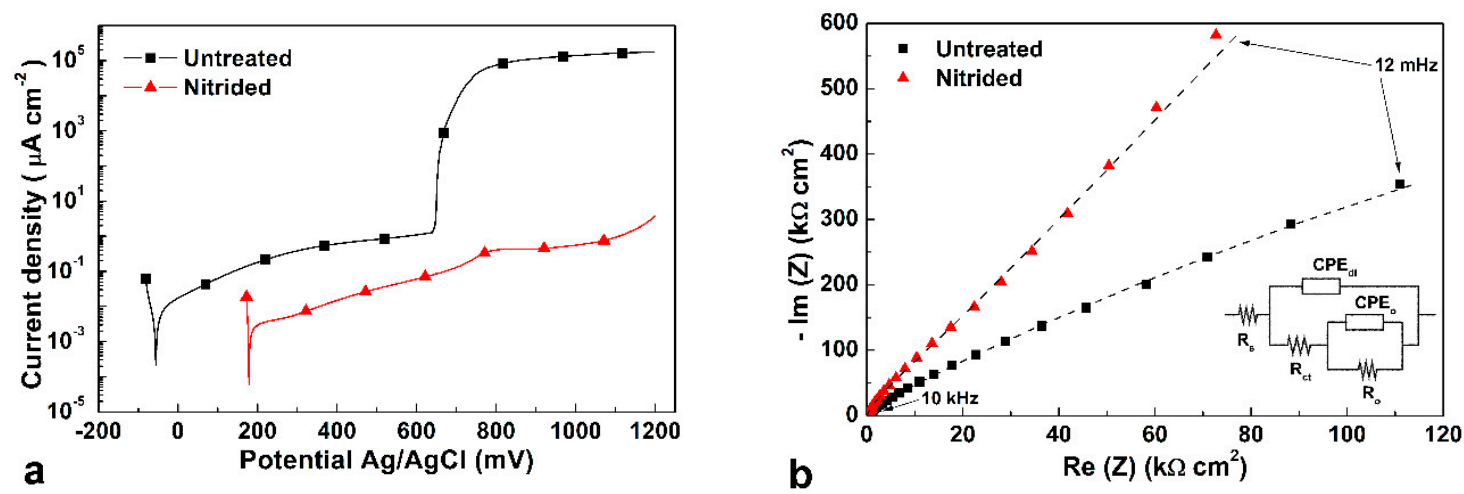

Figure 9. Corrosion behavior of AISI 316L samples untreated and plasma nitrided at $380{ }^{\circ} \mathrm{C}, 340 \mathrm{~Pa}, 3 \mathrm{~h}$ : (a) polarization curves; (b) Nyquist plots, recorded at the respective open circuit potential (symbols: experimental data; lines: modeled data using the equivalent electrical circuit drawn in (b). For the circuit: $R_{s}$, electrolyte resistance; $R_{c t}$, charge transfer resistance, $C P E_{d l}$, double layer/space charge capacitance, $\mathrm{R}_{\mathrm{O}}$, resistance of the oxide layer, $C P E_{\mathrm{O}}$ capacitance/mass transfer processes in the oxide layer) (solution: $5 \% \mathrm{NaCl}$, aerated). For further details, see [70].

Nitrided austenitic stainless steels also have an excellent resistance to crevice corrosion. AISI 316L samples plasma nitrided at $430{ }^{\circ} \mathrm{C}$ at $10 \mathrm{mbar}$ for $5 \mathrm{~h}$ did not show any observable crevice corrosion event after testing them in a $10 \% \mathrm{NaCl}$ solution at $55^{\circ} \mathrm{C}$ for 60 days, while for the untreated samples the first corrosion attack occurred after only 3 days [216]. AISI 316 specimens, gas nitrided at $430{ }^{\circ} \mathrm{C}$ for $20 \mathrm{~h}$, after $168 \mathrm{~h}$ showed a significantly lower weight loss, if compared to that of untreated steel, when they were tested in a $3 \mathrm{wt}$. $\% \mathrm{FeCl}_{3}$ solution of $\mathrm{pH} 1$ [228].

In addition to aqueous solutions of $\mathrm{NaCl}$, the nitrided samples also have an improved corrosion resistance when they are put in contact with chloride-ion saline solutions, as those used to simulate body fluids. When a S-phase layer forms, enhanced corrosion resistance has been shown by samples tested in Ringer's solution [218,229], phosphate-buffered saline (PBS) solution [223,224,230] and simulated body fluid (SBF) solution [231]. Lei and Zhu [229] tested AISI 316L and 1Cr18Ni9Ti, untreated and plasma source ion nitrided at $380^{\circ} \mathrm{C}$ for $4 \mathrm{~h}$, in Ringer's solutions at $\mathrm{pH}$ values in the range 3.5-7.2 at $37^{\circ} \mathrm{C}$, and they observed that the nitrided samples did not have pitting corrosion when the solution was at pH 7.2 and 5.5, due to the transpassivation solution of the passive films on the surface, while for $\mathrm{pH} 3.5$ a passivation-pitting corrosion transition was registered, even if the pitting potential was higher than that of the untreated steels.

Nitrided samples also have a good corrosion resistance in $\mathrm{HCl}$ solutions, in comparison with the untreated steels [81].

The marked improvement in corrosion resistance of low temperature nitrided stainless steels, which has been shown when the samples are tested in $\mathrm{NaCl}$ water solutions, is reduced when specimens are put in contact with $\mathrm{NaCl}+\mathrm{H}_{2} \mathrm{SO}_{4}$ solutions. Flisk-Kabulska et al. [135] registered a more anodic dissolution for plasma nitrided samples, in comparison with untreated alloy, even if the alkalinization due to the formation of $\mathrm{NH}_{4}{ }^{+}$ions is able to hinder pitting propagation. 
Low temperature carburizing has also demonstrated to be able to improve corrosion resistance in chloride-ion containing solutions [130,218,232-234]. It was supposed by Martin et al. [235] that $\mathrm{C}$ atoms, which are present in the passive film, act as mobile interstitials and enhance/maintain the oxygen vacancy motion. A further recent hypothesis, based on the analysis with grazing incidence $X$-ray photoelectron spectroscopy, suggested that the improved corrosion resistance of carburized specimens is related to the lower thickness of the passive film at a given potential, thus reducing the detrimental effect of thickness undulations of the oxide film, which can cause dielectric breakdown and pitting nucleation [236].

Enhanced corrosion resistance has been observed for nitrocarburized austenitic stainless steels $[60,154,218]$.

\subsubsection{Corrosion behavior in chloride-free acidic solutions}

As the research on $\mathrm{N}$ alloying, which has reported both positive $[6,237]$ and negative $[238,239]$ effects on general corrosion, the studies regarding the effects of low temperature nitriding on corrosion behavior in chloride-free acidic solutions are not univocal, since both the enhancement and decrease of corrosion resistance have been registered. Gontijo et al. [75] observed a slightly reduced corrosion resistance in a $0.1 \mathrm{M} \mathrm{H}_{2} \mathrm{SO}_{4}$ solution for nitrided samples, while Lei et al. [219] reported a slightly higher corrosion resistance in $0.5 \mathrm{M} \mathrm{H}_{2} \mathrm{SO}_{4}$ when the nitrided layer consisted of $\mathrm{S}$ phase only, but higher anodic currents when hcp $\varepsilon_{\mathrm{N}}{ }^{\prime}$ martensite was also able to form. It has been suggested that the corrosion behavior is related to the presence of surface defects, as slip lines, microtwins and dislocations, corresponding to high energy zones, which dissolve quickly and make repassivation difficult [47]. Kuczynska-Wydorska and Flis [240] examined the behavior of the nitrided layer at various depth for AISI 304L and AISI 316L samples, nitrided at $425^{\circ} \mathrm{C}$ for $30 \mathrm{~h}$, with tests in $0.1 \mathrm{M} \mathrm{Na}_{2} \mathrm{SO}_{4}$ acidified to $\mathrm{pH}$ 3. At low depths, with high $\mathrm{N}$ concentrations, the corrosion resistance decreased, while at deeper regions, with a $\mathrm{N}$ concentration below $\sim 7 \mathrm{wt} \%$, the corrosion resistance was comparable or even better than that of untreated steels. An initial acceleration of anodic oxidation was observed, which is beneficial since it leads to the formation of corrosion products that can precipitate and contribute to the passivation, and it was supposed to be related with nitride precipitates and/or higher anodic reactivity of the $S$ phase $[240,241]$.

\subsection{Electric Properties}

\subsubsection{Semiconducting Properties of the Passive Film}

The passive films formed on stainless steels have semiconducting properties, because the oxide layers are nonstoichiometric. The passive oxide films with a deficiency in metal ions or excess with cation vacancies usually behave as $p$-type (for example, $\mathrm{Cr}_{2} \mathrm{O}_{3}, \mathrm{MoO}_{2}$ and $\mathrm{FeCr}_{2} \mathrm{O}_{4}$ ), while a $n$-type behavior $\left(\mathrm{Fe}_{2} \mathrm{O}_{3}, \mathrm{MoO}_{3}, \alpha, \beta\right.$ and $\gamma \mathrm{FeO}(\mathrm{OH})$, etc.) is developed either by cation transport through interstitial diffusion or by anion diffusion toward the metal substrate [212]. In $\mathrm{NaCl}$ solutions Mott-Schottky plots usually register the presence of two different layers, an outer $n$-type layer composed of iron oxide/hydroxide and an inner $p$-type layer rich in chromium oxide [212]. A similar two-layer structure has been inferred by the Mott-Schottky analysis of plasma-based low-energy N ion implanted AISI 316L in 3.5\% NaCl solution, but both the donor and acceptor density values have been found to be significantly lower than those of the untreated alloy and a decrease of flat band potential, at which this transition occurs, has been registered [225]. Slightly lower decrease of donor density was observed by Sun [232], who tested low temperature carburized AISI 316L. It has been hypothesized that the lower donor density in the outer $n$-type iron oxide/hydroxide region decreases the pitting nucleation ability, hindering the chloride-ion adsorption [225]. A decrease of donor and acceptor densities and of the corresponding flat band potential has also been observed for nitrided AISI 304L tested in borate buffer solution at $\mathrm{pH} 8.4$ [242]. 


\subsubsection{Electric Properties of the Modified Layers}

Research has been carried out to study the electric behavior of the modified layers as a whole, but univocal results have not been found. Due to their high corrosion resistance nitrided layers have been tested for substituting graphite bipolar plates in proton exchange membrane fuel cells (PEMFC). Stainless steels usually show poor surface conductivity and insufficient corrosion resistance in the PEMFC working conditions. Tian et al. [243] tested AISI 316L samples plasma nitrided at $370{ }^{\circ} \mathrm{C}$ and found that the nitrided specimens had an improved corrosion resistance in PEMFC working conditions $\left(0.05 \mathrm{M} \mathrm{H}_{2} \mathrm{SO}_{4}+2 \mathrm{ppm} \mathrm{HF}\right.$ at $\left.70{ }^{\circ} \mathrm{C}\right)$ and surface conductivity. Low contact resistance, reaching values comparable to that of graphite plates, was registered by Kaestner et al. [244] for DC pulsed plasma nitrided AISI 304. The interfacial contact resistance, measured for active screen plasma nitrided AISI 316 samples, also showed a significant reduction, in comparison with untreated alloy, and it decreased as the nitriding temperature was increased from 370 to $450{ }^{\circ} \mathrm{C}$ [245]. On the contrary, studies performed on foils of AISI 316, carburized in order to obtain uniform $C$ concentration, have registered a decrease of electrical conductivity, if compared to that of untreated stainless steel [191]. Taking into account Hall-effect measurements, it has been hypothesized that this reduced conductivity has to be ascribed not to a reduced electron mobility, but to a reduction of conduction electron concentration.

\subsection{Magnetic properties}

It has been predicted that fcc $\gamma$-Fe can have a paramagnetic (nonmagnetic), ferromagnetic or antiferromagnetic behavior, depending on the separation of the Fe atoms [246,247]. Austenitic stainless steels have a paramagnetic behavior at room temperature and become antiferromagnetic at low temperatures [248], while the nitride $\gamma^{\prime}-\mathrm{Fe}_{4} \mathrm{~N}$ is reported to be ferromagnetic [249]. The first information about the magnetic properties of the modified layers obtained by low temperature nitriding was reported by Ichii et al. [18], who observed that the layer was ferromagnetic, even if no more experimental details were given. Williamson et al. [36] analyzed N-implanted AISI 304 stainless steel with CEMS and observed a change in the magnetic nature of the $S$ phase as the $N$ content and lattice parameter increased, with a transition from a predominant paramagnetic phase, when the $S$ phase had a low $\mathrm{N}$ content, to a ferromagnetic behavior, when the $\mathrm{S}$ phase had a $\mathrm{N}$ content of about 20 at. $\%$. The magnetic resonance was broad and was fitted with a distribution of magnetic hyperfine fields with an average value of $\sim 16 \mathrm{~T}$, significantly larger than the internal field of austenitic stainless steels at low temperatures, typically of the order of $2 \mathrm{~T}$ [248]. The CEMS analysis of AISI 304L nitrided at $400{ }^{\circ} \mathrm{C}$, performed by Martinavičius et al. [148], registered, for the $\mathrm{S}$ phase, a magnetic hyperfine split pattern, which had the isomer shift and the range of hyperfine field distribution similar to those of $\gamma^{\prime}-\mathrm{Fe}_{4} \mathrm{~N}$. The use of magnetic force microscopy (MFM) has allowed to obtain more information about the magnetic characteristics of the $S$ phase. Several authors $[89,165,166,250-252]$ have observed that the modified layer obtained with low temperature nitriding consists of two sub-layers, an outer ferromagnetic layer, with a magnetic domains structure, and an inner paramagnetic layer, characterized by a flat, non-magnetic signal, as depicted in Figure 10. By comparing the N composition profile obtained with second neutral mass spectroscopy (SNMS) with the MFM image for ion nitrided AISI 316 specimens, Basso et al. [250] found that the transition from a paramagnetic to ferromagnetic behavior occurs when the solubilized $\mathrm{N}$ content is about 14 at.\%. These authors hypothesized that the most important effect that governs the ferromagnetism of S phase above 14 at. $\%$ is related to $\mathrm{N}-\mathrm{Cr}$ preferential bonding and the consequent removal of $\mathrm{Cr} 3 d$ electrons from the metal alloy valence band. Wu et al. [166], comparing the MFM image of gas nitrided AISI 316L samples with the N profile obtained with Auger electron spectroscopy (AES), also found 14 at.\% as the threshold content for the paramagnetic-ferromagnetic transition, corresponding to a lattice increase of about $5 \%$, consistent with the theoretical predictions [247]. This magnetic transition has been supposed to be related to the discontinuity of lattice parameters values of $S$ phase observed for gas nitrided AISI 316L samples [104]. 


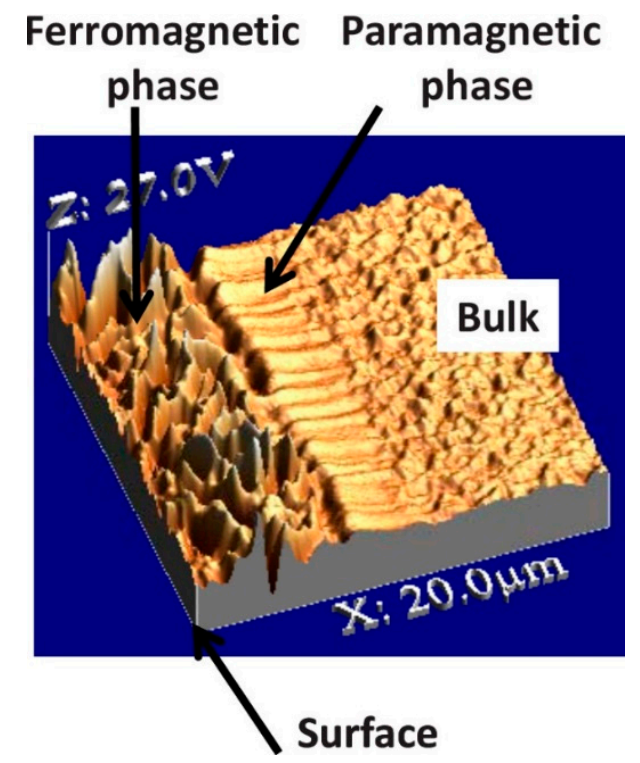

Figure 10. 3-D MFM image of an AISI 316 ion beam nitrided $\left(380{ }^{\circ} \mathrm{C}, 2 \mathrm{~h}\right)$ sample. The peaks in the outer layer represent the magnetic domains of the ferromagnetic phase. For further details, see [250]. (Reprinted from Journal of Applied Physics 105 (2009), R.L.O. Basso, V.L. Pimentel, S. Weber, G. Marcos, G, T Czerwiec, I.J.R. Baumvol, C.A. Figueroa, Magnetic and structural properties of ion nitrided stainless steel, 124914, with the permission of AIP Publishing).

In order to elucidate the influence of $\mathrm{N}$ content and lattice expansion on the magnetic properties of S phase, Brink et al. [147] analyzed homogeneous samples of the S phase, prepared nitriding thin foils of AISI 316, with magnetometry and Mössbauer spectroscopy. The magnetometry results pointed out that $\mathrm{S}$ phase is paramagnetic at room temperature for low $\left(11.5\right.$ at. $\left.\%, y_{\mathrm{N}}=0.13\right)$ and high (35.5 at.\%, $\left.y_{\mathrm{N}}=0.55\right) \mathrm{N}$ contents, and no distinct magnetic transition has been observed for temperatures down to $80 \mathrm{~K}$. On the contrary, samples with an intermediate $\mathrm{N}$ content $(22.5$ and 27.5 at. $\%$, corresponding to $y_{\mathrm{N}}=0.29$ and 0.38 , respectively) have a limited hysteresis, classifying them as soft ferromagnet, with Curie temperature values of $501 \mathrm{~K}(22.5$ at.\%) and $520 \mathrm{~K}$ (27.5 at.\%), significantly lower than that of $\gamma^{\prime}-\mathrm{Fe}_{4} \mathrm{~N}(767 \pm 10 \mathrm{~K}[249])$. The Mössbauer spectroscopy confirmed these observations and the spectra gave additional information on the configuration of Fe atoms. Even if samples having both low and high $\mathrm{N}$ content are paramagnetic, the sample with 11.5 at.\% had a coordination number for Fe of 0.53 , lower than that corresponding to a random distribution of $\mathrm{N}$ atoms over all the available octahedral sites (0.78), in accordance with the fact that $\mathrm{N}$ atoms have a preferential bonding with $\mathrm{Cr}$ atoms and form short-range ordered regions. For the specimen with 35.5 at.\% the calculated coordination number was 3.3, the expected value for a $\mathrm{N}$ content corresponding to $y_{\mathrm{N}}=0.55$, suggesting that for high $\mathrm{N}$ content the coordination number of $\mathrm{Fe}$ is not affected by the $\mathrm{Cr}-\mathrm{N}$ short-range ordered structures. However, the fitting of the Mössbauer spectra suggested that there was a clear deviation from a random distribution of $\mathrm{N}$ atoms, and that an ordering of $\mathrm{N}$ atoms in a primitive $\gamma^{\prime}-\mathrm{Fe}_{4} \mathrm{~N}$ cubic structure in long-range ordered domains might occur. The presence of very small peaks, characteristics of $\gamma^{\prime}-\mathrm{Fe}_{4} \mathrm{~N}$, was detected with a careful inspection of X-ray diffractograms of the nitrided specimens with a 35.5 at.\% $\mathrm{N}$ content, thus supporting the hypothesis of the formation of ordered structures. This observation is in accordance with the SAED patterns of nitrided samples observed with TEM, which have shown the presence of forbidden spots ascribable to a primitive lattice [35,142]. For the samples having a ferromagnetic behavior (22.5 and 27.5 at.\%) fitting of Mössbauer spectra suggested a less ordered structure than that of $\gamma^{\prime}-\mathrm{Fe}_{4} \mathrm{~N}$. Brink et al. [147] also reported that samples with a $\mathrm{N}$ content able to give them a ferromagnetic behavior at room temperature $\left(24.8\right.$ at. $\left.\%, y_{N}=0.33\right)$ showed a change in the linear thermal expansion coefficient from $9.66(4) \times 10^{-6} \mathrm{~K}^{-1}(341-549 \mathrm{~K})$ to $15.3(1) \times 10^{-6} \mathrm{~K}^{-1}$ (572-808 K), near the Curie temperature; as a comparison, austenite with no interstitial atoms has 
a thermal expansion coefficient of $18.5 \times 10^{-6} \mathrm{~K}^{-1}$ and $\gamma^{\prime}-\mathrm{Fe}_{4} \mathrm{~N}$ of $7.6 \times 10^{-6} \mathrm{~K}^{-1}$ [253]. It has been hypothesized that this change in expansion coefficient is related to variations in magnetic properties and that the fairly low expansion coefficient for the ferromagnetic $S$ phase is due to a spontaneous volume magnetostriction. The magnetic effect on the lattice parameter has been supposed to be also the cause of the shift between the lattice parameter values calculated for the N-rich $S$ phase and those calculated for the C-rich S phase. As reported in Section 4.4, for samples having a $\mathrm{N}$ content of about 14.5 at.\%, corresponding to $y_{\mathrm{N}}=0.17$, the lattice parameter of a N-rich $\mathrm{S}$ phase is $1.1 \%$ larger than that of a C-rich S phase having the same interstitial content, and it is $4.2 \%$ larger than interstitial free austenite. These interstitial content and lattice expansion values are in good agreement with the values of Wu et al. [166]. Due to the lower solubility of C atoms and lower lattice expansion (about 3\% max. [182]) the C-rich $S$ phase remains paramagnetic, and no ferromagnetic transition has been reported.

Thus, it has been hypothesized that $S$ phase remains paramagnetic as long as the interstitial content is lower than about $14 \%$ and the lattice expansion remains lower than about $4.2-5 \%$. Then a transition to the ferromagnetic behavior occurs, but when $\mathrm{N}$ content is fairly high (at a threshold value in the range $27.5-35.5$ at. \%, i.e., $0.38<y_{N}<0.55$, according to the results of [147]) $S$ phase becomes again paramagnetic.

The presence of two layers having different magnetic behavior might erroneously suggest that these layers are related to the two-layer microstructure observed with microscopy analysis (see Section 4.2). As a matter of fact, the comparison of atomic force microscopy (AFM) images of the modified layers, delineated by chemical etching, and the MFM images of the same layers has shown that the ferromagnetic layer is only a part of the outer modified layer observed with microscopy techniques, and that paramagnetic behavior is present in both the inner part of the S-phase layer and the layer consisting of the $\gamma(\mathrm{N}, \mathrm{C})$ phase $[165,166]$. This result is in accordance with the fact that the lattice expansion of $\gamma(\mathrm{N}, \mathrm{C})$ is usually very small (about $0.6 \%$ [68]), while the transition from a paramagnetic to ferromagnetic behavior takes place for a larger expansion of the fcc lattice (about 4.2-5\% [147,166]), which occurs within the S-phase layer.

The possibility of obtaining a ferromagnetic $S$ phase on a paramagnetic austenitic stainless substrate was used by Ménendez et al. [254] to produce periodic arrays of ferromagnetic structures with micrometric and submicrometric lateral sizes by means of ion beam nitriding through the use of shadow masks.

\subsection{Wetting Behavior}

Wetting behavior of a solid surface depends on the chemical composition, morphology and roughness of the surface itself $[255,256]$. When a drop of liquid is deposited on a real surface, the measured apparent contact angle (CA) (i.e., the angle between gas-liquid and solid-liquid interfaces) may increase or decrease in respect of the angle formed with a perfect flat surface depending on surface characteristics. The possible configurations are described by two different models, proposed by Wenzel [257] and Cassie and Baxter [258]. According to the Wenzel model, the drop has a complete contact with the surface, permeating the protrusions, so that surface roughness amplifies the wetting or the non-wetting behavior. According to the Cassie-Baxter model, drops, known as fakir drops, lay on a composite surface consisting of the top of the asperities and air pockets trapped underneath the liquid, so that the apparent CA is larger than that of a flat surface, and a hydrophilic surface $\left(\mathrm{CA}<90^{\circ}\right)$ may show a hydrophobic behavior $\left(\mathrm{CA}>90^{\circ}\right)$.

Since low temperature treatments are able to modify the surface morphology and roughness of samples, a change of wetting behavior is expected. Few studies have evaluated the wetting properties of low temperature treated austenitic stainless steels [78,79,117,127,128,177,223,259], and they have mainly regarded nitriding treatments and water wetting properties. Lin et al. [128] tested the water wettability of AISI 303 samples subjected to plasma nitriding at $450{ }^{\circ} \mathrm{C}$, which produced modified layers consisting of $\mathrm{S}$ phase. As the treatment duration was increased, the $\mathrm{N}$ content and surface 
roughness increased, while a decrease of CA, measured with the sessile drop method, was registered, from $103.5^{\circ}$ (untreated; polished surface) to $61.9^{\circ}$ (80 min nitriding). The authors related this wetting behavior only to $\mathrm{N}$ content, and supposed that the increase in hydrophilicity was due to the presence of hydrophilic functional groups such as N-H radicals due to the plasma treatment. Buhagiar et al. [259] investigated the water wetting behavior of plasma nitrided, carburized and nitrocarburized AISI 316LVM and high-N ASTM F1586 steels and they observed a decrease of CA for the nitrided and nitrocarburized samples, and an increase for the carburized specimens. A decrease of CA values was also observed by El-Hossary et al. [78] for AISI 304L and two experimental alloys, SSMn6Ni and SSMn10N, subjected to a RF plasma nitrocarburizing treatment which produced modified surface layers consisting of $\mathrm{S}$ phase, $\mathrm{CrN}$ and $\mathrm{Fe}_{3} \mathrm{C}$, and this behavior was ascribed to the increase of surface roughness. Galeano-Osorio et al. [177] reported a decrease of the CA of $2.5 \mu \mathrm{L}$ drops of deionized water and diiodomethane on the surface of AISI 316L samples plasma nitrided at 380 and $400{ }^{\circ} \mathrm{C}$ (400 $\mathrm{Pa}, 2 \mathrm{~h}$ ), and they hypothesized that this behavior was due to the appearance of polar groups at the surface, such as $\mathrm{OH}^{-}, \mathrm{N}-\mathrm{O} / \mathrm{N}-\mathrm{H}$, detected by XPS analysis. Water CA values similar to those measured for untreated samples were reported for specimens nitrided at $420{ }^{\circ} \mathrm{C}$, where the presence of $\mathrm{N}-\mathrm{O} / \mathrm{N}-\mathrm{H}$ bonds was smaller and $\mathrm{OH}^{-}$tended to desorb. Braz et al. [260] observed a significant decrease of contact angle values for drops $(20 \mu \mathrm{l})$ of deionized water on the surface of plasma nitrided $\left(450{ }^{\circ} \mathrm{C}, 100 \mathrm{~Pa}, 1 \mathrm{~h}\right)$ AISI 316L specimens $\left(71.81^{\circ}\right)$, in comparison with untreated ones $\left(100.13^{\circ}\right)$.

Borgioli et al. [117] investigated the water wetting behavior of AISI 316L and AISI 202 samples, subjected to plasma nitriding treatments at different temperatures $\left(380\right.$ and $\left.400{ }^{\circ} \mathrm{C}\right)$ and pressures (130 and $500 \mathrm{~Pa}$ ), which produced different surface morphology changes and roughness increase. When the drops of 0.5 or $3 \mu \mathrm{L}$ were carefully deposited on the surface, a marked increase of CA values was observed (from $78^{\circ}$ to $94^{\circ}$, depending on alloy and treatment conditions), in comparison with untreated samples (about $70^{\circ}$ ), suggesting the formation of fakir drops in a Cassie-Baxter state. On the other hand, when the drops were pushed on the surface, CA values as low as $63^{\circ}$, comparable to that reported by Lin et al. [128], were reported, so that a nearly Wenzel state may be hypothesized. Aizawa et al. [79] also observed a hydrophobic behavior for RF plasma nitrided AISI 316. Martinesi et al. [223] reported an increase of CA from $72.8^{\circ}$ to $82^{\circ}$ after plasma nitriding at $400{ }^{\circ} \mathrm{C}$ and $500 \mathrm{~Pa}$, but a decrease to $71^{\circ}$, when the nitrided samples were subjected to a sterilization procedure with ethanol and incubation with $2.5 \mathrm{mM} / \mathrm{mL}$ acetic acid for $24 \mathrm{~h}$, while no significant changes were observed for untreated specimens. An increase of apparent CA values for AISI 202 samples, having a polished or a 2D finishing, was observed after nitriding with different conditions, when 0.5 and $3 \mu \mathrm{L}$ drops of bi-distilled water or a solution of $3.5 \% \mathrm{NaCl}$ were used [127]. The highest CA values were registered for samples subjected to a low pressure process, similar to cathodic sputtering performed with a N-containing atmosphere, and CA as high as $110^{\circ}$ was measured on samples with a $2 \mathrm{D}$ finishing. In spite of the low hydrophilicity, and even hydrophobicity, shown by all the nitrided samples types, when liquids having a low surface tension, as ethanol and rapeseed oil, were used as probe, very low CA values were registered, suggesting an oleophilic behavior [127].

The different water wetting behavior of plasma nitrided specimens, as reported by the above mentioned authors, with a decrease of CA, suggesting a Wenzel state or a modification of surface chemical composition of passive layer, or an increase of CA, suggesting a Cassie-Baxter state, can be due to different factors, which are not necessarily related to roughness or chemical modifications due to the nitriding treatments. It is well known that austenitic stainless steels are hydrophilic, even with a fairly large CA, but surface contamination is able to increase CA [261], while surface treatments as plasma treatment are able to reduce it [261,262]. Moreover, the time passed after plasma treatment for developing a stable passive layer or cleaning procedure before wetting tests may influence the apparent CA, as well as drop size, which can produce a transition from a Cassie-Baxter state to a Wenzel state due to hydrostatic pressure. 


\subsection{Biocompatibility}

The improvement of corrosion resistance in chloride-ion containing solutions due to the formation of $S$ phase suggests that low temperature treatments are suitable for body implants, put in contact with body fluids. One of the first papers regarding the biocompatibility of low temperature nitrided austenitic stainless steels was that of Bordji et al. [263]. Their results were not encouraging: when put in contact with plasma nitrided $\left(400^{\circ} \mathrm{C}, 300 \mathrm{~Pa}\right)$ AISI 316L samples, human osteoblast and fibroblast viability significantly decreased, while for a slight $\mathrm{N}$ ion implanted or C-doped samples it remained comparable with that of untreated steel. Better results were registered by Buhagiar et al. [259] who tested plasma nitrided $\left(430{ }^{\circ} \mathrm{C}, 400 \mathrm{~Pa}, 15 \mathrm{~h}\right)$, carburized $\left(500{ }^{\circ} \mathrm{C}, 400 \mathrm{~Pa}, 15 \mathrm{~h}\right)$ and nitrocarburized $\left(430{ }^{\circ} \mathrm{C}, 400 \mathrm{~Pa}, 15 \mathrm{~h}\right.$ ) AISI 316LVM (ASTM F138) and high-N ASTM F1586 samples putting them in contact with mouse osteoblasts. Higher cell proliferation was observed on treated samples than on untreated ones, and a relatively high cell proliferation occurred on the nitrocarburized specimens, suggesting that osteoblast cells prefer surfaces rich in $\mathrm{N}$ and $\mathrm{C}$. Martinesi et al. [264] tested in vitro the biocompatibility of plasma nitrided $\left(430{ }^{\circ} \mathrm{C}, 10^{3}\right.$ and $\left.2 \times 10^{3} \mathrm{~Pa}, 5 \mathrm{~h}\right)$ AISI $316 \mathrm{~L}$ specimens put in contact with human umbilical vein endothelial cells (HUVEC) and human peripheral blood mononuclear cells (PBMC), evaluating proliferation, apoptosis and some biological markers associated with inflammation. The authors observed the same good level of cytocompatibility for untreated and treated samples when proliferation, apoptosis and cytokine released by HUVEC were considered, while cytokine released by PBMC and the increase in adhesion molecules levels suggested that consequences were occurring on a metabolic point of view. Low temperature nitriding has been reported to be a suitable treatment to act as a substrate for collagen coating [223,224,230]. When plasma nitrided $\left(400{ }^{\circ} \mathrm{C}, 500 \mathrm{~Pa}\right.$, $5 \mathrm{~h}$ ) and collagen coated AISI 316L samples were put in contact with HUVEC, significant higher cell proliferation was observed after 5 days for this sample type, in comparison with that registered for samples untreated and collagen coated or subjected only to plasma nitriding treatment, and a smaller release of metalloproteinase (MMP)-2, related to extracellular matrix degradation, was detected [223]. Biocompatibility of AISI 316L untreated and plasma nitrided (400 ${ }^{\circ} \mathrm{C}, 500 \mathrm{~Pa}, 5 \mathrm{~h}$ ) with or without collagen coating was also tested incubating the samples with human PBMC [230]. The results showed that proliferation, viability and MMP-9 secretion were not negatively affected by the contact with the sample types, but a remarkable increase of the secretion of some pro-inflammatory cytokines was registered, in comparison with control cells. However, for the nitrided and collagen coated specimens a decrease of the pro-inflammatory cytokine Interleukin (IL)-1 $\beta$ and an increase of anti-inflammatory cytokine IL-10 were observed, if compared to untreated steel. Testing with HUVEC-PBMC co-cultures pointed out that nitriding treatment, with or without collagen coating, can ameliorate some biological parameters [224]. Studies on the biocompatibility of plasma nitrided $\left(450{ }^{\circ} \mathrm{C}, 100 \mathrm{~Pa}, 1 \mathrm{~h}\right)$ AISI $316 \mathrm{~L}$ specimens, incubated with rabbit aorta endothelial cells, showed that in presence of this sample type a higher cell viability was registered, in comparison with polished untreated steel, and late cellular apoptosis was reduced [260].

Hemocompatibility of plasma $\left(450{ }^{\circ} \mathrm{C}, 7.5 \mathrm{~Pa}, 40-80 \mathrm{~min}\right)$ nitrided AISI 303 steel was assessed by Lin et al. [128], and these authors found that the nitrided samples had lower platelet adhesion and activation, if compared to untreated steel, and the clotting time for this sample type was prolonged and increased with nitriding duration. A recent study of Galeano-Osorio et al. [177] on the hemocompatibility and thrombogenicity of plasma nitrided $\left(380-420{ }^{\circ} \mathrm{C}, 400 \mathrm{~Pa}, 2 \mathrm{~h}\right)$ AISI $316 \mathrm{~L}$ samples put in light that the behavior of the nitrided samples depends on treatment temperature: lower amount and less activation of platelets were registered on samples nitrided at $380{ }^{\circ} \mathrm{C}$, while the highest one for samples treated at $420^{\circ} \mathrm{C}$. This result was correlated with the hydrophobicity and roughness of the nitrided layers, which were higher as the treatment temperature increased. 


\section{Conclusions}

The studies on the $\mathrm{S}$ phase are showing that this metastable phase is more complex than a supersaturated solid solution of interstitial atoms in the expanded and distorted austenite lattice, as it is usually described. The preferential bond of interstitial atoms ( $\mathrm{N}$ and $\mathrm{C}$ ) with $\mathrm{Cr}$ produces short-range ordered structures, which can form nanometric precipitates coherent with the interstitial-rich fcc matrix. For a high $\mathrm{N}$ content, the presence of long-range ordered structures, similar to Fe nitride $\gamma^{\prime}-\mathrm{Fe}_{4} \mathrm{~N}$, has been inferred, probably forming domain structures. Together with these structures having a chemical origin, stress-related structures may also form, as "clustered" stacking faults, which locally cause a hcp lattice arrangement analogous to that of hcp $\varepsilon^{\prime}$ martensite. $\mathrm{N}$ content is able to cause the change from a paramagnetic behavior, typical of austenitic stainless steels at room temperature, to a ferromagnetic behavior.

The characteristics of the $\mathrm{S}$ phase are dependent on the interstitial atom type supplied by low temperature treatment, i.e., $\mathrm{N}$ and $\mathrm{C}$, as briefly summarized in Table 1.

Table 1. Main characteristics on N-rich and C-rich S phase.

\begin{tabular}{ccc}
\hline Properties & N-rich S Phase & C-rich S Phase \\
\hline Formation temperature $\left({ }^{\circ} \mathrm{C}\right)$ & $300-450$ & $300-550$ \\
Max. interstitial content $($ at. $\%)$ & 38 & 19 \\
Max. surface hardness & 1450 & 1000 \\
Hardness profile & abrupt change & gradual change \\
Toughness & poor & good \\
high \\
Load bearing capacity & low & good \\
Dry sliding wear resistance & very good & good \\
Localized corrosion resistance & very good & paramagnetic \\
Magnetic properties & paramagnetic $\left(\mathrm{N}<14\right.$ at. $\% ; \mathrm{N}=35.5$ at. $\left.\%{ }^{1}\right)$ & 350 \\
Threshold temperature for & ferromagnetic $(\mathrm{N}>14$ at. $\%)$ & \\
decomposition $\left({ }^{\circ} \mathrm{C}\right)$ & 300 &
\end{tabular}

${ }^{1}$ Homogeneous N-rich S phase samples [147].

For the applications and in-service behavior of low temperature treated austenitic stainless steels it has to be reminded that the $S$ phase, as a metastable phase, tends to transform when it is exposed to fairly high temperatures. The threshold temperature, at which the decomposition begins after thousands of hours, depends on interstitial atom type, and the C-rich S phase has a higher threshold temperature than the $\mathrm{N}$-rich phase. Extrapolations of experimental data suggest that an upper service temperature of about $200{ }^{\circ} \mathrm{C}$ is required to have a long term stability ( $>10$ years) of S-phase layers.

Thus, as point out by all the research carried out since 1980s, the $S$ phase is a valuable mean for improving the hardness, fatigue resistance, tribological properties and corrosion resistance of austenitic stainless steels. Moreover, owing to its magnetic and electric properties, wetting behavior and biocompatibility the use of surface treated austenitic stainless steels can be extended further on.

Funding: This research received no external funding.

Acknowledgments: AIP Publishing and Elsevier are acknowledged for the permission to use the figures.

Conflicts of Interest: The author declares no conflict of interest.

\section{References}

1. Washko, S.D.; Aggen, G. Wrought Stainless Steels. In ASM Handbook; ASM International: Materials Park, OH, USA, 1997; Volume 1, pp. 841-907.

2. McGuire, M.F. Stainless Steels for Design Engineers; ASM International: Materials Park, OH, USA, 2008; ISBN 978-0-87170-717-8. 
3. Lo, K.H.; Shek, C.H.; Lai, J.K.L. Recent developments in stainless steels. Mater. Sci. Eng. R Rep. 2009, 65, 39-104. [CrossRef]

4. Charles, J. The new 200 Series: An alternative answer to Ni surcharge? Dream or nightmare? In Proceedings of the Fifth Stainless Steel Science and Market Congress, Stainless Steel '05, Sevilla, Spain, 27-30 September 2005; Odriozola, J.A., Paúl, A., Eds.; Centro de Investigaciones Científicas Isla de la Cartuja: Sevilla, Spain, 2005; pp. 19-27.

5. Simmons, J.W. Overview: High-nitrogen alloying of stainless steels. Mater. Sci. Eng. A 1996, 207, $159-169$. [CrossRef]

6. Hänninen, H.; Romu, J.; Ilola, R.; Tervo, J.; Laitinen, A. Effects of processing and manufacturing of high nitrogen-containing stainless steels on their mechanical, corrosion and wear properties. J. Mater. Process. Technol. 2001, 117, 424-430. [CrossRef]

7. Speidel, M.O. Nitrogen Containing Austenitic Stainless Steels. Materwiss. Werksttech. 2006, 37, 875-880. [CrossRef]

8. Ghali, S.N. Low Carbon High Nitrogen Low Nickel Stainless Steel. Steel Res. Int. 2013, 84, 450-456. [CrossRef]

9. Talha, M.; Behera, C.K.; Sinha, O.P. A review on nickel-free nitrogen containing austenitic stainless steels for biomedical applications. Mater. Sci. Eng. C 2013, 33, 3563-3575. [CrossRef] [PubMed]

10. Park, J.Y.; Park, S.-J.; Kang, J.-Y.; Lee, C.-H.; Ha, H.-Y.; Moon, J.; Jang, J.H.; Lee, T.-H. Fatigue behaviors of high nitrogen stainless steels with different deformation modes. Mater. Sci. Eng. A 2017, 682, 622-628. [CrossRef]

11. Baba, H.; Kodama, T.; Katada, Y. Role of nitrogen on the corrosion behavior of austenitic stainless steels. Corros. Sci. 2002, 44, 2393-2407. [CrossRef]

12. Mudali, U.K.; Ningshen, S. Corrosion properties of nitrogen bearing stainless steels. In High Nitrogen Steels and Stainless Steels—Manufacturing Properties and Applications; Mudali, U.K., Raj, B., Eds.; Alpha Science International Ltd.: Pangbourne, UK, 2004; pp. 133-181.

13. Speidel, M.O. Corrosion Science of Stainless Steels. Proceedings of International Conference on Stainless Steels, Stainless Steels ‘91, Chiba, Japan, 10-13 June 1991; Iron and Steel Institute of Japan: Tokyo, Japan, 1991; Volume 1, pp. 25-35.

14. Lampman, S. Introduction to Surface Hardening of Steels. In ASM Handbook; ASM International: Materials Park, OH, USA, 1997; Volume 4, pp. 259-267.

15. O'Brien, J.M.; Goodman, D. Plasma (ion) nitriding. In ASM Handbook; ASM International: Materials Park, OH, USA, 1997; Volume 4, pp. 420-424.

16. Davis, J.R. Surface Engineering of Stainless Steels. In ASM Metal Handbook; ASM International: Materials Park, OH, USA, 1994; Volume 5, pp. 741-761. [CrossRef]

17. Bell, T. Surface engineering of austenitic stainless steel. Surf. Eng. 2002, 18, 415-422. [CrossRef]

18. Ichii, K.; Fujimura, K.; Takase, T. Structure of the ion-nitrided layer of 18-8 stainless steel. Technol. Rep. Kansai Univ. 1986, 27, 135-144.

19. Zhang, Z.L.; Bell, T. Structure and Corrosion Resistance of Plasma Nitrided Stainless Steel. Surf. Eng. 1985, 1, 131-136. [CrossRef]

20. Zhang, Z.L.; Bell, T. Structure and corrosion resistance of plasma-nitrided AISI 316 stainless steel. In Proceedings of the Third International Congress on Heat Treatment of Materials, Heat Treatment Shanghai '83, Shanghai, China, 7-11 November 1983; Bell, T., Ed.; The Metals Society: London, UK, 1984; p. 6.25 .

21. De Benedetti, B.; Angelini, E.; Zucchi, F. Nitrurazione ionica di acciai inossidabili. In Proceedings of the 10th National Congress on Thermal Treatments, Salsomaggiore, Italy, 16-18 October 1984; Associazione Italiana di Metallurgia: Milan, Italy, 1984; pp. 81-88.

22. De Benedetti, B.; Angelini, E.; Zucchi, F. Nitrurazione ionica di acciai inossidabili. La Metall. Ital. 1985, 77, 615-621.

23. Angelini, E.; Burdese, A.; De Benedetti, B. Ion-nitriding of austenitic stainless steels. Metall. Sci. Technol. 1988, 6, 33-39.

24. Ichii, K.; Fujimura, K.; Takase, T. Microstructure, Corrosion Resistance, and Hardness of the Surface layer in Ion Nitrided 18-8 Stainless Steel. Netsu Shori 1985, 25, 191-195.

25. Yasumaru, N.; Kamachi, K. Nitrogen-induced Phase Transformation in Type 304 Austenitic Stainless Steel. J. Japan Inst. Met. 1986, 50, 362-368. [CrossRef] 
26. Edenhofer, B. The ionitriding process-Thermochemical treatment of steel and cast iron materials. Metall. Mater. Technol. 1976, 8, 421-426.

27. Lebrun, J.-P.; Michel, H.; Gantois, M. Nitruration par bombardement ionique des aciers inoxydables 18-10. Mémoires Sci. La Rev. Métallurgie 1972, 69, 727-738.

28. Lerner, R.M. Glow-discharge nitriding of Nitralloy 135M and AISI304 stainless steel. J. Iron Steel Inst. 1972, 210, 631-632.

29. Spalvins, T. Tribological and microstructural characteristics of ion-nitrided steels. Thin Solid Films 1983, 108, 157-163. [CrossRef]

30. Vardiman, R.G.; Singer, I.L. Transformation of stress-induced martensite in 304 stainless steel by ion implantation. Mater. Lett. 1983, 2, 150-154. [CrossRef]

31. Somers, M.A.J.; Christiansen, T.L. Low temperature surface hardening of stainless steel. In Thermochemical Surface Engineering of Steels; Mittemeijer, E.J., Somers, M.A.J., Eds.; Woodhead Publishing: Oxford, UK, 2015; pp. 557-579. ISBN 978-0-85709-592-3. [CrossRef]

32. Kolster, B.H. Verschleiß- und korrosionsfeste Schichten auf austenitischen Stälen. VDI. Ber. 1983, 506, 107-113.

33. Holcomb, W.F. Carburization of type 304 stainless steel in liquid sodium. Nucl. Eng. Des. 1967, 6, $264-272$. [CrossRef]

34. Kolster, B.H. Mechanism of Fe and Cr transport by liquid sodium in non-isothermal loop systems. J. Nucl. Mater. 1975, 55, 155-168. [CrossRef]

35. Hannula, S.-P.; Nenonen, P.; Hirvonen, J.-P. Surface structure and properties of ion-nitrided austenitic stainless steels. Thin Solid Films 1989, 181, 343-350. [CrossRef]

36. Williamson, D.L.; Ozturk, O.; Wei, R.; Wilbur, P.J. Metastable phase formation and enhanced diffusion in f.c.c. alloys under high dose, high flux nitrogen implantation at high and low ion energies. Surf. Coatings Technol. 1994, 65, 15-23. [CrossRef]

37. Marchev, K.; Cooper, C.V.; Blucher, J.T.; Giessen, B.C. Conditions for the formation of a martensitic single-phase compound layer in ion-nitrided 316L austenitic stainless steel. Surf. Coatings Technol. 1998, 99, 225-228. [CrossRef]

38. Fossati, A.; Borgioli, F.; Galvanetto, E.; Bacci, T. Glow-discharge nitriding of AISI 316L austenitic stainless steel: Influence of treatment time. Surf. Coatings Technol. 2006, 200, 3511-3517. [CrossRef]

39. Sun, Y.; Li, X.; Bell, T. Low temperature plasma carburising of austenitic stainless steels for improved wear and corrosion resistance. Surf. Eng. 1999, 15, 49-54. [CrossRef]

40. Collins, S.R.; Williams, P.C.; Marx, S.V.; Heuer, A.; Ernst, F.; Kahn, H. Low-Temperature Carburization of Austenitic Stainless Steels. In ASM Handbook; Dosset, J., Totten, G.E., Eds.; ASM International: Materials Park, OH, USA, 2014; Volume 4D, pp. 451-460.

41. Czerwiec, T.; Renevier, N.; Michel, H. Low-temperature plasma-assisted nitriding. Surf. Coatings Technol. 2000, 131, 267-277. [CrossRef]

42. Czerwiec, T.; He, H.; Marcos, G.; Thiriet, T.; Weber, S.; Michel, H. Fundamental and Innovations in Plasma Assisted Diffusion of Nitrogen and Carbon in Austenitic Stainless Steels and Related Alloys. Plasma Process. Polym. 2009, 6, 401-409. [CrossRef]

43. Bell, T. Current Status of Supersaturated Surface Engineered S-Phase Materials. Key Eng. Mater. 2008, 373-374, 289-295. [CrossRef]

44. Luo, Q.; Yang, S. From Micro to Nano Scales -Recent Progress in the Characterization of Nitrided Austenitic Stainless Steels. Int. J. Nanomed. Nanosurgery 2015, 1, 1. [CrossRef]

45. Fossati, A.; Galvanetto, E.; Bacci, T.; Borgioli, F. Improvement of corrosion resistance of austenitic stainless steels by means of glow-discharge nitriding. Corros. Rev. 2011, 29, 209-221. [CrossRef]

46. Somers, M.; Kücükyildiz, Ö.; Ormstrup, C.; Alimadadi, H.; Hattel, J.; Christiansen, T.; Winther, G. Residual Stress in Expanded Austenite on Stainless Steel; Origin, Measurement, and Prediction. Mater. Perform. Charact. 2018, 7, 693-716. [CrossRef]

47. Dong, H. S-phase surface engineering of Fe-Cr, $\mathrm{Co}-\mathrm{Cr}$ and Ni-Cr alloys. Int. Mater. Rev. 2010, 55, 65-98. [CrossRef]

48. Christiansen, T.L.; Somers, M.A.J. Low-temperature gaseous surface hardening of stainless steel: The current status. Zeitschrift fuer Met. Res. Adv. Tech. 2009, 100, 1361-1377. [CrossRef]

49. Shankar, P.; Sundararaman, D.; Ranganathan, S. Clustering and ordering of nitrogen in nuclear grade 316LN austenitic stainless steel. J. Nucl. Mater. 1998, 254, 1-8. [CrossRef] 
50. Wriedt, H.A.; Gokcen, N.A.; Nafziger, R.H. The Fe-N (Iron-Nitrogen) system. Bull. Alloy. Phase Diagrams 1987, 8, 355-377. [CrossRef]

51. Okamoto, H. The C-Fe (carbon-iron) system. J. Phase Equilibria 1992, 13, 543-565. [CrossRef]

52. Cao, Y.; Ernst, F.; Michal, G.M. Colossal carbon supersaturation in austenitic stainless steels carburized at low temperature. Acta Mater. 2003, 51, 4171-4181. [CrossRef]

53. Christiansen, T.; Somers, M.A.J. Controlled dissolution of colossal quantities of nitrogen in stainless steel. Metall. Mater. Trans. A 2006, 37, 675-682. [CrossRef]

54. Christiansen, T.L.; Ståhl, K.; Brink, B.K.; Somers, M.A.J. On the Carbon Solubility in Expanded Austenite and Formation of Hägg Carbide in AISI 316 Stainless Steel. Steel Res. Int. 2016, 87, 1395-1405. [CrossRef]

55. Buhagiar, J.; Li, X.; Dong, H. Formation and microstructural characterisation of S-phase layers in Ni-free austenitic stainless steels by low-temperature plasma surface alloying. Surf. Coat. Technol. 2009, 204, 330-335. [CrossRef]

56. Wu, D.; Ge, Y.; Kahn, H.; Ernst, F.; Heuer, A.H. Diffusion profiles after nitrocarburizing austenitic stainless steel. Surf. Coat. Technol. 2015, 279, 180-185. [CrossRef]

57. Christiansen, T.; Somers, M.A.J. Low temperature gaseous nitriding and carburising of stainless steel. Surf. Eng. 2005, 21, 445-455. [CrossRef]

58. Cheng, Z.; Li, C.X.; Dong, H.; Bell, T. Low temperature plasma nitrocarburising of AISI 316 austenitic stainless steel. Surf. Coat. Technol. 2005, 191, 195-200. [CrossRef]

59. Bottoli, F.; Winther, G.; Christiansen, T.L.; Dahl, K.V.; Somers, M.A.J. Low-Temperature Nitriding of Deformed Austenitic Stainless Steels with Various Nitrogen Contents Obtained by Prior High-Temperature Solution Nitriding. Metall. Mater. Trans. A 2016, 47, 4146-4159. [CrossRef]

60. Sun, Y. Hybrid plasma surface alloying of austenitic stainless steels with nitrogen and carbon. Mater. Sci. Eng. A 2005, 404, 124-129. [CrossRef]

61. Wang, S.; Cai, W.; Li, J.; Wei, W.; Hu, J. A novel rapid D.C. plasma nitriding at low gas pressure for 304 austenitic stainless steel. Mater. Lett. 2013, 105, 47-49. [CrossRef]

62. Borgioli, F.; Fossati, A.; Galvanetto, E.; Bacci, T.; Pradelli, G. Glow discharge nitriding of AISI 316L austenitic stainless steel: Influence of treatment pressure. Surf. Coat. Technol. 2006, 200, 5505-5513. [CrossRef]

63. Lu, S.; Zhao, X.; Wang, S.; Li, J.; Wei, W.; Hu, J. Performance enhancement by plasma nitriding at low gas pressure for 304 austenitic stainless steel. Vacuum 2017, 145, 334-339. [CrossRef]

64. Yasumaru, N. Low-Temperature Ion Nitriding of Austenitic Sainless Steels. Mater. Trans. JIM 1998, 39, 1046-1052. [CrossRef]

65. Yasumaru, N. Nature of $\mathrm{Y}_{\mathrm{N}}$ phase formed with low temperature plasma nitriding of austenitic stainless steels. In Stainless Steel 2000: Thermochemical Surface Engineering of Stainless Steel; Bell, T., Akamatsu, K., Eds.; The Institute of Materials: London, UK, 2001; pp. 229-245.

66. Williamson, D.L.; Davis, J.A.; Wilbur, P.J. Effect of austenitic stainless steel composition on low-energy, high-flux, nitrogen ion beam processing. Surf. Coat. Technol. 1998, 103-104, 178-184. [CrossRef]

67. Tao, X.; Matthews, A.; Leyland, A. On the Nitrogen-Induced Lattice Expansion of a Non-stainless Austenitic Steel, Invar $36^{\circledR}$, Under Triode Plasma Nitriding. Metall. Mater. Trans. A 2019. [CrossRef]

68. Borgioli, F.; Fossati, A.; Matassini, G.; Galvanetto, E.; Bacci, T. Low temperature glow-discharge nitriding of a low nickel austenitic stainless steel. Surf. Coat. Technol. 2010, 204, 3410-3417. [CrossRef]

69. Borgioli, F.; Fossati, A.; Raugei, L.; Galvanetto, E.; Bacci, T. Low temperature glow-discharge nitriding of stainless steels. In Proceedings of the 7th European Stainless Steel Conference: Science and Market, Como, Italy, 21-23 September 2011; Associazione Italiana di Metallurgia: Milan, Italy, 2011.

70. Borgioli, F.; Galvanetto, E.; Bacci, T. Corrosion behaviour of low temperature nitrided nickel-free, AISI 200 and AISI 300 series austenitic stainless steels in $\mathrm{NaCl}$ solution. Corros. Sci. 2018. [CrossRef]

71. Borgioli, F.; Galvanetto, E.; Bacci, T. Low temperature nitriding of AISI 300 and 200 series austenitic stainless steels. Vacuum 2016, 127, 51-60. [CrossRef]

72. Egawa, M.; Ueda, N.; Nakata, K.; Tsujikawa, M.; Tanaka, M. Effect of additive alloying element on plasma nitriding and carburizing behavior for austenitic stainless steels. Surf. Coatings Technol. 2010, 205, S246-S251. [CrossRef]

73. Christiansen, T.L.; Dahl, K.V.; Somers, M.A.J. New Stainless Steel Alloys for Low Temperature Surface Hardening? BHM Berg- und Hüttenmännische Monatshefte 2015, 160, 406-412. [CrossRef] 
74. Menthe, E.; Rie, K.-T.; Schultze, J.W.; Simson, S. Structure and properties of plasma-nitrided stainless steel. Surf. Coat. Technol. 1995, 74-75, 412-416. [CrossRef]

75. Gontijo, L.C.; Machado, R.; Kuri, S.E.; Casteletti, L.C.; Nascente, P.A.P. Corrosion resistance of the layers formed on the surface of plasma-nitrided AISI 304L steel. Thin Solid Films 2006, 515, 1093-1096. [CrossRef]

76. Czerwiec, T.; He, H.; Weber, S.; Dong, C.; Michel, H. On the occurrence of dual diffusion layers during plasma-assisted nitriding of austenitic stainless steel. Surf. Coat. Technol. 2006, 200, 5289-5295. [CrossRef]

77. Mitchell, D.R.G.; Attard, D.J.; Collins, G.A.; Short, K.T. Characterisation of $\mathrm{PI}^{3}$ and RF plasma nitrided austenitic stainless steels using plan and cross-sectional TEM techniques. Surf. Coat. Technol. 2003, 165, 107-118. [CrossRef]

78. El-Hossary, F.M.; El-Kameesy, S.U.; Eissa, M.M.; Abd El-Moula, A.A.; Al-Shelkamy, S.A. Influence of Rf plasma carbonitriding on AISI304L, SSMn6Ni and SSMn10Ni for nuclear applications. Mater. Res. Express 2019, 6, 096596. [CrossRef]

79. Aizawa, T.; Morita, H.; Wasa, K. Low-temperature plasma nitriding of mini-/micro-tools and parts by table-top system. Appl. Sci. 2019, 9, 1667. [CrossRef]

80. Li, C.X.; Bell, T. Sliding wear properties of active screen plasma nitrided 316 austenitic stainless steel. Wear 2004, 256, 1144-1152. [CrossRef]

81. Li, C.X.; Bell, T. Corrosion properties of active screen plasma nitrided 316 austenitic stainless steel. Corros. Sci. 2004, 46, 1527-1547. [CrossRef]

82. Gallo, S.C.; Dong, H. Study of active screen plasma processing conditions for carburising and nitriding austenitic stainless steel. Surf. Coat. Technol. 2009, 203, 3669-3675. [CrossRef]

83. Wei, R.; Vajo, J.J.; Matossian, J.N.; Wilbur, P.J.; Davis, J.A.; Williamson, D.L.; Collins, G.A. A comparative study of beam ion implantation, plasma ion implantation and nitriding of AISI 304 stainless steel. Surf. Coat. Technol. 1996, 83, 235-242. [CrossRef]

84. Abrasonis, G.; Rivière, J.P.; Templier, C.; Muzard, S.; Pranevicius, L. Influence of surface preparation and ion flux on the nitriding efficiency of austenitic stainless steel. Surf. Coat. Technol. 2005, 196, 279-283. [CrossRef]

85. Borgioli, F.; Galvanetto, E.; Bacci, T. Surface modification of austenitic stainless steel by means of low pressure glow-discharge treatments with nitrogen. Coatings 2019, 9, 604. [CrossRef]

86. Somers, M.A.J.; Christiansen, T.L. Gaseous processes for low temperature surface hardening of stainless steel. In Thermochemical Surface Engineering of Steels; Mittemeijer, E.J., Somers, M.A.J., Eds.; Woodhead Publishing: Oxford, UK, 2015; pp. 581-614. ISBN 978-0-85709-592-3. [CrossRef]

87. Somers, M.A.J.; Christiansen, T.; Møller, P. Case-Hardening of Stainless Steel. International Bureau of the World Intellectual Property Organization (WIPO). WO Patent 200,400,7789, 22 January 2004.

88. Williams, P.C.; Marx, S.V. Low temperature case hardening processes. US Patent 6,461,448 B1, 8 October 2002.

89. Baranowska, J. Importance of surface activation for nitrided layer formation on austenitic stainless steel. Surf. Eng. 2010, 26, 293-298. [CrossRef]

90. Collins, S.; Williams, P. Low-temperature colossal supersaturation. Adv. Mater. Process. 2006, 164, 32.

91. Baranowska, J.; Kusior, E.; Amigo, V.; Szczeciński, K. Surface modification of austenitic steel by low-temperature plasma. Vacuum 2005, 78, 389-394. [CrossRef]

92. Sun, Y.; Bell, T. A numerical model of plasma nitriding of low alloy steels. Mater. Sci. Eng. A 1997, $224,33-47$. [CrossRef]

93. Mändl, S.; Scholze, F.; Neumann, H.; Rauschenbach, B. Nitrogen diffusivity in expanded austenite. Surf. Coatings Technol. 2003, 174-175, 1191-1195. [CrossRef]

94. Christiansen, T.; Dahl, K.V.; Somers, M.A.J. Nitrogen diffusion and nitrogen depth profiles in expanded austenite: Experimental assessment, numerical simulation and role of stress. Mater. Sci. Technol. 2008, 24, 159-167. [CrossRef]

95. Williamson, D.L.; Ivanov, I.; Wei, R.; Wilbur, P.J. Role of Chromium in High-Dose, High-Rate, Elevated Temperature Nitrogen Implantation of Austenitic Stainless Steels. MRS Proc. 1991, 235, 473. [CrossRef]

96. Parascandola, S.; Möller, W.; Williamson, D.L. The nitrogen transport in austenitic stainless steel at moderate temperatures. Appl. Phys. Lett. 2000, 76, 2194-2196. [CrossRef]

97. Parascandola, S.; Günzel, R.; Grötzschel, R.; Richter, E.; Möller, W. Analysis of deuterium induced nuclear reactions giving criteria for the formation process of expanded austenite. Nucl. Instrum. Methods Phys. Res. Sect. B Beam Interact. with Mater. Atoms 1998, 136-138, 1281-1285. [CrossRef] 
98. Christiansen, T.L.; Drouet, M.; Martinavičius, A.; Somers, M.A.J. Isotope exchange investigation of nitrogen redistribution in expanded austenite. Scr. Mater. 2013, 69, 582-585. [CrossRef]

99. Galdikas, A.; Moskalioviene, T. Modeling of stress induced nitrogen diffusion in nitrided stainless steel. Surf. Coat. Technol. 2011, 205, 3742-3746. [CrossRef]

100. Moskalioviene, T.; Galdikas, A. Stress induced and concentration dependent diffusion of nitrogen in plasma nitrided austenitic stainless steel. Vacuum 2012, 86, 1552-1557. [CrossRef]

101. Christiansen, T.L.; Somers, M.A.J. The Influence of Stress on Interstitial Diffusion-Carbon Diffusion Data in Austenite Revisited. Defect Diffus. Forum 2010, 297-301, 1408-1413. [CrossRef]

102. Jespersen, F.N.; Hattel, J.H.; Somers, M.A.J. Modelling the evolution of composition-and stress-depth profiles in austenitic stainless steels during low-temperature nitriding. Model. Simul. Mater. Sci. Eng. 2016, 24, 25003. [CrossRef]

103. Martinavičius, A.; Abrasonis, G.; Möller, W.; Templier, C.; Rivière, J.P.; Declémy, A.; Chumlyakov, Y. Anisotropic ion-enhanced diffusion during ion nitriding of single crystalline austenitic stainless steel. J. Appl. Phys. 2009, 105, 93502. [CrossRef]

104. Wu, D.; Kahn, H.; Dalton, J.C.; Michal, G.M.; Ernst, F.; Heuer, A.H. Orientation dependence of nitrogen supersaturation in austenitic stainless steel during low-temperature gas-phase nitriding. Acta Mater. 2014, 79, 339-350. [CrossRef]

105. Moskalioviene, T.; Galdikas, A. Kinetic model of anisotropic stress assisted diffusion of nitrogen in nitrided austenitic stainless steel. Surf. Coat. Technol. 2019, 366, 277-285. [CrossRef]

106. Kücükyildiz, Ö.C.; Sonne, M.R.; Thorborg, J.; Somers, M.A.J.; Hattel, J.H. Thermo-chemical-mechanical simulation of low temperature nitriding of austenitic stainless steel; inverse modelling of surface reaction rates. Surf. Coatings Technol. 2020, 381, 125145. [CrossRef]

107. Li, X.Y. Low Temperature Plasma Nitriding of 316 Stainless Steel - Nature of S Phase and Its Thermal Stability. Surf. Eng. 2001, 17, 147-152. [CrossRef]

108. Christiansen, T.; Somers, M.A.J. Decomposition kinetics of expanded austenite with high nitrogen contents. Zeitschrift fuer Met. Res. Adv. Tech. 2006, 97, 79-88.

109. Collins, G.A.; Hutchings, R.; Short, K.T.; Tendys, J.; Li, X.; Samandi, M. Nitriding of austenitic stainless steel by plasma immersion ion implantation. Surf. Coat. Technol. 1995, 74-75, 417-424. [CrossRef]

110. Tao, X.; Liu, X.; Matthews, A.; Leyland, A. The influence of stacking fault energy on plasticity mechanisms in triode-plasma nitrided austenitic stainless steels: Implications for the structure and stability of nitrogen-expanded austenite. Acta Mater. 2019, 164, 60-75. [CrossRef]

111. Mändl, S.; Günzel, R.; Richter, E.; Möller, W.; Rauschenbach, B. Annealing behaviour of nitrogen implanted stainless steel. Surf. Coat. Technol. 2000, 128-129, 423-428. [CrossRef]

112. Li, X.Y.; Thaiwatthana, S.; Dong, H.; Bell, T. Thermal stability of carbon S phase in 316 stainless steel. Surf. Eng. 2002, 18, 448-451. [CrossRef]

113. Ernst, F.; Cao, Y.; Michal, G.M. Carbides in low-temperature-carburized stainless steels. Acta Mater. 2004, 52, 1469-1477. [CrossRef]

114. Liang, W.; Xiaolei, X.; Jiujun, X.; Yaqin, S. Characteristics of low pressure plasma arc source ion nitrided layer on austenitic stainless steel at low temperature. Thin Solid Films 2001, 391, 11-16. [CrossRef]

115. Nosei, L.; Farina, S.; Ávalos, M.; Náchez, L.; Gómez, B.J.; Feugeas, J. Corrosion behavior of ion nitrided AISI 316L stainless steel. Thin Solid Films 2008, 516, 1044-1050. [CrossRef]

116. Borgioli, F.; Fossati, A.; Galvanetto, E.; Bacci, T. Glow-discharge nitriding of AISI 316L austenitic stainless steel: Influence of treatment temperature. Surf. Coat. Technol. 2005, 200, 2474-2480. [CrossRef]

117. Borgioli, F.; Galvanetto, E.; Bacci, T. Influence of surface morphology and roughness on water wetting properties of low temperature nitrided austenitic stainless steels. Mater. Charact. 2014, 95, 278-284. [CrossRef]

118. Baranowska, J.; Arnold, B. Corrosion resistance of nitrided layers on austenitic steel. Surf. Coatings Technol. 2006, 200, 6623-6628. [CrossRef]

119. Baranowska, J.; Franklin, S.E.; Kochmańska, A. Wear behaviour of low-temperature gas nitrided austenitic stainless steel in a corrosive liquid environment. Wear 2007, 263, 669-673. [CrossRef]

120. Stinville, J.C.; Cormier, J.; Templier, C.; Villechaise, P. Modeling of the lattice rotations induced by plasma nitriding of 316L polycrystalline stainless steel. Acta Mater. 2015, 83, 10-16. [CrossRef]

121. Manova, D.; Lutz, J.; Mändl, S. Sputtering effects during plasma immersion ion implantation of metals. Surf. Coat. Technol. 2010, 204, 2875-2880. [CrossRef] 
122. Stinville, J.C.; Villechaise, P.; Templier, C.; Riviere, J.P.; Drouet, M. Plasma nitriding of 316L austenitic stainless steel: Experimental investigation of fatigue life and surface evolution. Surf. Coat. Technol. 2010, 204, 1947-1951. [CrossRef]

123. Stinville, J.C.; Templier, C.; Villechaise, P.; Pichon, L. Swelling of 316L austenitic stainless steel induced by plasma nitriding. J. Mater. Sci. 2011, 46, 5503-5511. [CrossRef]

124. Abrasonis, G.; Rivière, J.P.; Templier, C.; Declémy, A.; Pranevicius, L.; Milhet, X. Ion beam nitriding of single and polycrystalline austenitic stainless steel. J. Appl. Phys. 2005, 97, 83531. [CrossRef]

125. Stinville, J.C.; Villechaise, P.; Templier, C.; Rivière, J.P.; Drouet, M. Lattice rotation induced by plasma nitriding in a 316L polycrystalline stainless steel. Acta Mater. 2010, 58, 2814-2821. [CrossRef]

126. Templier, C.; Stinville, J.C.; Villechaise, P.; Renault, P.O.; Abrasonis, G.; Rivière, J.P.; Martinavičius, A.; Drouet, M. On lattice plane rotation and crystallographic structure of the expanded austenite in plasma nitrided AISI 316L steel. Surf. Coat. Technol. 2010, 204, 2551-2558. [CrossRef]

127. Borgioli, F.; Galvanetto, E.; Bacci, T. Effects of surface modification by means of low temperature plasma nitriding on wetting behavior of austenitic stainless steel. Coatings 2020, 10, 98. [CrossRef]

128. Lin, Y.H.; Lan, W.C.; Ou, K.L.; Liu, C.M.; Peng, P.W. Hemocompatibility evaluation of plasma-nitrided austenitic stainless steels at low temperature. Surf. Coat. Technol. 2012, 206, 4785-4790. [CrossRef]

129. Farrell, K.; Specht, E.D.; Pang, J.; Walker, L.R.; Rar, A.; Mayotte, J.R. Characterization of a carburized surface layer on an austenitic stainless steel. J. Nucl. Mater. 2005, 343, 123-133. [CrossRef]

130. Formosa, D.; Hunger, R.; Spiteri, A.; Dong, H.; Sinagra, E.; Buhagiar, J. Corrosion behaviour of carbon S-phase created on Ni-free biomedical stainless steel. Surf. Coat. Technol. 2012, 206, 3479-3487. [CrossRef]

131. Gallo, S.C.; Dong, H. EBSD and AFM observations of the microstructural changes induced by low temperature plasma carburising on AISI 316. Appl. Surf. Sci. 2011, 258, 608-613. [CrossRef]

132. Michler, T. Influence of plasma nitriding on hydrogen environment embrittlement of 1.4301 austenitic stainless steel. Surf. Coat. Technol. 2008, 202, 1688-1695. [CrossRef]

133. Toshkov, V.; Russev, R.; Madjarov, T.; Russeva, E. On low temperature ion nitriding of austenitic stainless steel AISI 316. J. Achiev. Mater. Manuf. Eng. 2007, 25, 71-74.

134. Sun, Y.; Li, X.Y.; Bell, T. X-ray diffraction characterisation of low temperature plasma nitrided austenitic stainless steels. J. Mater. Sci. 1999, 34, 4793-4802. [CrossRef]

135. Flis-Kabulska, I.; Sun, Y.; Flis, J. Monitoring the near-surface $\mathrm{pH}$ to probe the role of nitrogen in corrosion behaviour of low-temperature plasma nitrided 316L stainless steel. Electrochim. Acta 2013, 104, 208-215. [CrossRef]

136. Talonen, J.; Hänninen, H. Formation of shear bands and strain-induced martensite during plastic deformation of metastable austenitic stainless steels. Acta Mater. 2007, 55, 6108-6118. [CrossRef]

137. Lei, M.K. Phase transformations in plasma source ion nitrided austenitic stainless steel at low temperature. J. Mater. Sci. 1999, 34, 5975-5982. [CrossRef]

138. Bracke, L.; Mertens, G.; Penning, J.; De Cooman, B.C.; Liebeherr, M.; Akdut, N. Influence of phase transformations on the mechanical properties of high-strength austenitic Fe-Mn-Cr steel. Metall. Mater. Trans. A 2006, 37, 307-317. [CrossRef]

139. Qi-Xun, D.; Xiao-Nong, C.; An-Dong, W.; Xin-Min, L. Stacking fault energy of cryogenic austenitic steels. Chin. Phys. 2002, 11, 596-600. [CrossRef]

140. Yakubtsov, I.A.; Ariapour, A.; Perovic, D.D. Effect of nitrogen on stacking fault energy of f.c.c. iron-based alloys. Acta Mater. 1999, 47, 1271-1279. [CrossRef]

141. Tong, K.; Ye, F.; Che, H.; Lei, M.K.; Miao, S.; Zhang, C. High-density stacking faults in a supersaturated nitrided layer on austenitic stainless steel. J. Appl. Crystallogr. 2016, 49, 1967-1971. [CrossRef]

142. Stróż, D.; Psoda, M. TEM studies of plasma nitrided austenitic stainless steel. J. Microsc. 2010, 237, $227-231$. [CrossRef]

143. Jiang, J.C.; Meletis, E.I. Microstructure of the nitride layer of AISI 316 stainless steel produced by intensified plasma assisted processing. J. Appl. Phys. 2000, 88, 4026-4031. [CrossRef]

144. Xu, X.L.; Wang, L.; Yu, Z.W.; Hei, Z.K. Microstructural characterization of plasma nitrided austenitic stainless steel. Surf. Coat. Technol. 2000, 132, 270-274. [CrossRef]

145. Xiaolei, X.; Liang, W.; Zhiwei, Y.; Zukun, H. A comparative study on microstructure of the plasma-nitrided layers on austenitic stainless steel and pure Fe. Surf. Coat. Technol. 2005, 192, 220-224. [CrossRef] 
146. Che, H.L.; Tong, S.; Wang, K.S.; Lei, M.K.; Somers, M.A.J. Co-existence of $\gamma_{\mathrm{N}}^{\prime}$ phase and $\gamma_{\mathrm{N}}$ phase on nitrided austenitic Fe-Cr-Ni alloys- I. experiment. Acta Mater. 2019, 177, 35-45. [CrossRef]

147. Brink, B.K.; Ståhl, K.; Christiansen, T.L.; Frandsen, C.; Hansen, M.F.; Somers, M.A.J. Composition-dependent variation of magnetic properties and interstitial ordering in homogeneous expanded austenite. Acta Mater. 2016, 106, 32-39. [CrossRef]

148. Martinavičius, A.; Abrasonis, G.; Scheinost, A.C.; Danoix, R.; Danoix, F.; Stinville, J.C.; Talut, G.; Templier, C.; Liedke, O.; Gemming, S.; et al. Nitrogen interstitial diffusion induced decomposition in AISI 304L austenitic stainless steel. Acta Mater. 2012, 60, 4065-4076. [CrossRef]

149. Martinavičius, A.; Danoix, R.; Drouet, M.; Templier, C.; Hannoyer, B.; Danoix, F. Atom probe tomography characterization of nitrogen induced decomposition in low temperature plasma nitrided $304 \mathrm{~L}$ austenitic stainless steel. Mater. Lett. 2015, 139, 153-156. [CrossRef]

150. Sasidhar, K.N.; Meka, S.R. Thermodynamic reasoning for colossal N supersaturation in austenitic and ferritic stainless steels during low-temperature nitridation. Sci. Rep. 2019, 9, 7996. [CrossRef] [PubMed]

151. Mändl, S.; Rauschenbach, B. Concentration dependent nitrogen diffusion coefficient in expanded austenite formed by ion implantation. J. Appl. Phys. 2002, 91, 9737-9742. [CrossRef]

152. Tsujikawa, M.; Yamauchi, N.; Ueda, N.; Sone, T.; Hirose, Y. Behavior of carbon in low temperature plasma nitriding layer of austenitic stainless steel. Surf. Coat. Technol. 2005, 193, 309-313. [CrossRef]

153. Bottoli, F.; Christiansen, T.L.; Winther, G.; Somers, M.A.J. Effect of Plastic Pre-straining on Residual Stress and Composition Profiles in Low-Temperature Surface-Hardened Austenitic Stainless Steel. Metall. Mater. Trans. A 2016, 47, 4001-4011. [CrossRef]

154. Sun, Y.; Haruman, E. Effect of carbon addition on low-temperature plasma nitriding characteristics of austenitic stainless steel. Vacuum 2006, 81, 114-119. [CrossRef]

155. Li, X.Y.; Buhagiar, J.; Dong, H. Characterisation of dual S phase layer on plasma carbonitrided biomedical austenitic stainless steels. Surf. Eng. 2010, 26, 67-73. [CrossRef]

156. Gu, X.; Michal, G.M.; Ernst, F.; Kahn, H.; Heuer, A.H. Numerical Simulations of Carbon and Nitrogen Composition-Depth Profiles in Nitrocarburized Austenitic Stainless Steels. Metall. Mater. Trans. A 2014, 45, 4268-4279. [CrossRef]

157. Sun, Y.; Li, X.; Bell, T. Structural characteristics of low temperature plasma carburised austenitic stainless steel. Mater. Sci. Technol. 1999, 15, 1171-1178. [CrossRef]

158. Dahm, K.L.; Betts, A.J.; Dearnley, P.A. Chemical structure and corrosion behaviour of S phase coatings. Surf. Eng. 2010, 26, 271-276. [CrossRef]

159. Riviere, J.P.; Cahoreau, M.; Meheust, P. Chemical bonding of nitrogen in low energy high flux implanted austenitic stainless steel. J. Appl. Phys. 2002, 91, 6361-6366. [CrossRef]

160. Jiang, S.; Ma, X.; Sun, Y.; Sun, M. Corrosion behavior of AISI302 steel treated by elevated temperature nitrogen plasma immersion ion implantation. Scr. Mater. 2005, 53, 1427-1432. [CrossRef]

161. Riviere, J.P.; Meheust, P.; Villain, J.P.; Templier, C.; Cahoreau, M.; Abrasonis, G.; Pranevicius, L. High current density nitrogen implantation of an austenitic stainless steel. Surf. Coat. Technol. 2002, 158-159, 99-104. [CrossRef]

162. Oddershede, J.; Christiansen, T.L.; Ståhl, K.; Somers, M.A.J. Extended X-ray absorption fine structure investigation of nitrogen stabilized expanded austenite. Scr. Mater. 2010, 62, 290-293. [CrossRef]

163. Tong, K.; Ye, F.; Wang, Y.K. Short-range ordered structure and phase stability of supersaturated nitrided layer on austenitic stainless steel. Acta Mater. 2019, 175, 314-323. [CrossRef]

164. Oddershede, J.; Christiansen, T.L.; Ståhl, K.; Somers, M.A.J. Extended X-Ray absorption fine structure investigation of carbon stabilized expanded austenite and carbides in stainless steel AISI 316. Steel Res. Int. 2011, 82, 1248-1254. [CrossRef]

165. Fewell, M.P.; Mitchell, D.R.G.; Priest, J.M.; Short, K.T.; Collins, G.A. The nature of expanded austenite. Surf. Coat. Technol. 2000, 131, 300-306. [CrossRef]

166. Wu, D.; Kahn, H.; Michal, G.M.; Ernst, F.; Heuer, A.H. Ferromagnetism in interstitially hardened austenitic stainless steel induced by low-temperature gas-phase nitriding. Scr. Mater. 2011, 65, 1089-1092. [CrossRef]

167. Blawert, C.; Kalvelage, H.; Mordike, B.L.; Collins, G.A.; Short, K.T.; Jirásková, Y.; Schneeweiss, O. Nitrogen and carbon expanded austenite produced by $\mathrm{PI}^{3}$. Surf. Coat. Technol. 2001, 136, 181-187. [CrossRef]

168. Cullity, B.D. Elements of X-ray Diffraction; Addison-Wesley Publishing Company, Inc.: Reading, MA, USA, 1956; pp. 324-343. 
169. Öztürk, O.; Williamson, D.L. Phase and composition depth distribution analyses of low energy, high flux N implanted stainless steel. J. Appl. Phys. 1995, 77, 3839-3850. [CrossRef]

170. Marchev, K.; Landis, M.; Vallerio, R.; Cooper, C.V.; Giessen, B.C. The $m$ phase layer on ion nitrided austenitic stainless steel (III): An epitaxial relationship between the $m$ phase and the $\gamma$ parent phase and a review of structural identifications of this phase. Surf. Coat. Technol. 1999, 116-119, 184-188. [CrossRef]

171. Bacci, T.; Borgioli, F.; Galvanetto, E.; Pradelli, G. Glow-discharge nitriding of sintered stainless steels. Surf. Coat. Technol. 2001, 139, 251-256. [CrossRef]

172. Fewell, M.P.; Priest, J.M. High-order diffractometry of expanded austenite using synchrotron radiation. Surf. Coat. Technol. 2008, 202, 1802-1815. [CrossRef]

173. Mändl, S.; Rauschenbach, B. Anisotropic strain in nitrided austenitic stainless steel. J. Appl. Phys. 2000, 88, 3323-3329. [CrossRef]

174. Christiansen, T.; Somers, M.A.J. Avoiding ghost stress on reconstruction of stress- and composition-depth profiles from destructive X-ray diffraction depth profiling. Mater. Sci. Eng. A 2006, 424, 181-189. [CrossRef]

175. Lei, M.K.; Liang, J. X-ray diffraction of high nitrogen face centred cubic phase formed on nitrogen modified austenitic stainless steel. Surf. Eng. 2010, 26, 305-311. [CrossRef]

176. Warren, B.E. X-ray Diffraction; Addison-Wesley Publishing Company, Inc.: Reading, MA, USA, 1969; pp. 275-298.

177. Galeano-Osorio, D.S.; Vargas, S.; Vélez, J.M.; Mello, A.; Tanaka, M.N.; Castano, C.E. Hemocompatibility of plasma nitrided 316L stainless steel: Effect of Processing Temperature. Appl. Surf. Sci. 2019, 144704. [CrossRef]

178. Velterop, L.; Delhez, R.; de Keijser, T.H.; Mittemeijer, E.J.; Reefman, D. X-ray diffraction analysis of stacking and twin faults in f.c.c. metals: A revision and allowance for texture and non-uniform fault probabilities. J. Appl. Crystallogr. 2000, 33, 296-306. [CrossRef]

179. Brink, B.K.; Ståhl, K.; Christiansen, T.L.; Oddershede, J.; Winther, G.; Somers, M.A.J. On the elusive crystal structure of expanded austenite. Scr. Mater. 2017, 131, 59-62. [CrossRef]

180. Clausen, B.; Lorentzen, T.; Leffers, T. Self-consistent modelling of the plastic deformation of f.c.c. polycrystals and its implications for diffraction measurements of internal stresses. Acta Mater. 1998, 46, 3087-3098. [CrossRef]

181. Christiansen, T.L.; Hummelshøj, T.S.; Somers, M.A.J. Expanded austenite, crystallography and residual stress. Surf. Eng. 2010, 26, 242-247. [CrossRef]

182. Hummelshøj, T.S.; Christiansen, T.L.; Somers, M.A.J. Lattice expansion of carbon-stabilized expanded austenite. Scr. Mater. 2010, 63, 761-763. [CrossRef]

183. Ledbetter, H.M.; Austin, M.W. Dilation of an fcc Fe-Cr-Ni alloy by interstitial carbon and nitrogen. Mater. Sci. Technol. 1987, 3, 101-104. [CrossRef]

184. Oddershede, J.; Christiansen, T.L.; Ståhl, K.; Somers, M.A.J. EXAFS investigation of low temperature nitrided stainless steel. J. Mater. Sci. 2008, 43, 5358-5367. [CrossRef]

185. Grigull, S.; Parascandola, S. Ion-nitriding induced plastic deformation in austenitic stainless steel. J. Appl. Phys. 2000, 88, 6925-6927. [CrossRef]

186. Fernandes, F.A.P.; Christiansen, T.L.; Winther, G.; Somers, M.A.J. On the determination of stress profiles in expanded austenite by grazing incidence X-ray diffraction and successive layer removal. Acta Mater. 2015, 94, 271-280. [CrossRef]

187. Fernandes, F.A.P.; Christiansen, T.L.; Winther, G.; Somers, M.A.J. Measurement and tailoring of residual stress in expanded austenite on austenitic stainless steel. Mater. Sci. Eng. A 2017, 701, 167-173. [CrossRef]

188. Christiansen, T.L.; Somers, M.A.J. Stress and Composition of Carbon Stabilized Expanded Austenite on Stainless Steel. Metall. Mater. Trans. A 2008, 40, 1791. [CrossRef]

189. Jegou, S.; Christiansen, T.L.; Klaus, M.; Genzel, C.; Somers, M.A.J. Determination of composition, residual stress and stacking fault depth profiles in expanded austenite with energy-dispersive diffraction. Thin Solid Films 2013, 530, 71-76. [CrossRef]

190. Tromas, C.; Stinville, J.C.; Templier, C.; Villechaise, P. Hardness and elastic modulus gradients in plasma-nitrided 316L polycrystalline stainless steel investigated by nanoindentation tomography. Acta Mater. 2012, 60, 1965-1973. [CrossRef]

191. Ren, Z.; Ernst, F. Electronic impact of concentrated interstitial carbon on physical properties of AISI-316 austenitic stainless steel. Acta Mater. 2019, 173, 96-105. [CrossRef] 
192. Thaiwatthana, S.; Li, X.Y.; Dong, H.; Bell, T. Comparison studies on properties of nitrogen and carbon S phase on low temperature plasma alloyed AISI 316 stainless steel. Surf. Eng. 2002, 18, 433-437. [CrossRef]

193. Stinville, J.C.; Cormier, J.; Templier, C.; Villechaise, P. Monotonic mechanical properties of plasma nitrided 316L polycrystalline austenitic stainless steel: Mechanical behaviour of the nitrided layer and impact of nitriding residual stresses. Mater. Sci. Eng. A 2014, 605, 51-58. [CrossRef]

194. Michal, G.M.; Ernst, F.; Kahn, H.; Cao, Y.; Oba, F.; Agarwal, N.; Heuer, A.H. Carbon supersaturation due to paraequilibrium carburization: Stainless steels with greatly improved mechanical properties. Acta Mater. 2006, 54, 1597-1606. [CrossRef]

195. Sun, Y.; Bell, T. Sliding wear characteristics of low temperature plasma nitrided 316 austenitic stainless steel. Wear 1998, 218, 34-42. [CrossRef]

196. Ceschini, L.; Chiavari, C.; Marconi, A.; Martini, C. Influence of the countermaterial on the dry sliding friction and wear behaviour of low temperature carburized AISI316L steel. Tribol. Int. 2013, 67, 36-43. [CrossRef]

197. Sun, Y.; Bell, T. Dry sliding wear resistance of low temperature plasma carburised austenitic stainless steel. Wear 2002, 253, 689-693. [CrossRef]

198. Hoshiyama, Y.; Mizobata, R.; Miyake, H. Mechanical properties of austenitic stainless steel treated by active screen plasma nitriding. Surf. Coat. Technol. 2016, 307, 1041-1044. [CrossRef]

199. Fossati, A.; Borgioli, F.; Galvanetto, E.; Bacci, T. Resistenza ad usura di acciai inossidabili austenitici nitrurati in scarica ionica. Metall. Ital. 2007, 99, 29-34.

200. O’Donnell, L.J.; Michal, G.M.; Ernst, F.; Kahn, H.; Heuer, A.H. Wear maps for low temperature carburised 316L austenitic stainless steel sliding against alumina. Surf. Eng. 2010, 26, 284-292. [CrossRef]

201. De Las Heras, E.; Santamaría, D.G.; García-Luis, A.; Cabo, A.; Brizuela, M.; Ybarra, G.; Mingolo, N.; Brühl, S.; Corengia, P. Microstructure and Wear Behavior of DC-Pulsed Plasma Nitrided AISI 316L Austenitic Stainless Steel. Plasma Process. Polym. 2007, 4, S741-S745. [CrossRef]

202. Sun, Y.; Bell, T. Effect of Layer Thickness on the Rolling-Sliding Wear Behavior of Low-Temperature Plasma-Carburized Austenitic Stainless Steel. Tribol. Lett. 2002, 13, 29-34. [CrossRef]

203. Duarte, M.C.S.; Godoy, C.; Wilson, J.C.A.-B. Analysis of sliding wear tests of plasma processed AISI 316L steel. Surf. Coat. Technol. 2014, 260, 316-325. [CrossRef]

204. Ceschini, L.; Minak, G. Fatigue behaviour of low temperature carburised AISI 316L austenitic stainless steel. Surf. Coat. Technol. 2008, 202, 1778-1784. [CrossRef]

205. Peng, Y.; Liu, Z.; Chen, C.; Gong, J.; Somers, M.A.J. Effect of low-temperature surface hardening by carburization on the fatigue behavior of AISI 316L austenitic stainless steel. Mater. Sci. Eng. A 2020, 769, 138524. [CrossRef]

206. Wang, K.S.; Che, H.L.; Lei, M.K. Corrosion-fatigue properties of plasma-based low-energy nitrogen ion implanted AISI 304L austenitic stainless steel in borate buffer solution. Surf. Coat. Technol. 2016, 288, 30-35. [CrossRef]

207. Jargelius-Pettersson, R.F.A. Electrochemical investigation of the influence of nitrogen alloying on pitting corrosion of austenitic stainless steels. Corros. Sci. 1999, 41, 1639-1664. [CrossRef]

208. Olefjord, I.; Wegrelius, L. The influence of nitrogen on the passivation of stainless steels. Corros. Sci. 1996, 38, 1203-1220. [CrossRef]

209. Baba, H.; Katada, Y. Effect of nitrogen on crevice corrosion in austenitic stainless steel. Corros. Sci. 2006, 48, 2510-2524. [CrossRef]

210. Ives, M.B.; Lu, Y.C.; Luo, J.L. Cathodic reactions involved in metallic corrosion in chlorinated saline environments. Corros. Sci. 1991, 32, 91-102. [CrossRef]

211. Clayton, C.R.; Rosenzweig, L.; Oversluizen, M.; Lu, Y.C. The influence of nitrogen on the passivity of 18-8 (0.24\%N) stainless steels. In Surfaces, Inhibition and Passivation; McCafferty, E., Brodd, R.J., Eds.; The Electrochemical Society: Pennington, NJ, USA, 1986; pp. 323-339.

212. Ningshen, S.; Mudali, U.K.; Mittal, V.K.; Khatak, H.S. Semiconducting and passive film properties of nitrogen-containing type 316LN stainless steels. Corros. Sci. 2007, 49, 481-496. [CrossRef]

213. Vehovar, L.; Vehovar, A.; Metikoš-Huković, M.; Tandler, M. Investigations into the stress corrosion cracking of stainless steel alloyed with nitrogen. Mater. Corros. 2002, 53, 316-327. [CrossRef]

214. Bayoumi, F.M.; Ghanem, W.A. Effect of nitrogen on the corrosion behavior of austenitic stainless steel in chloride solutions. Mater. Lett. 2005, 59, 3311-3314. [CrossRef] 
215. Zhu, X.M.; Lei, M.K. Pitting corrosion resistance of high nitrogen f.c.c. phase in plasma source ion nitrided austenitic stainless steel. Surf. Coat. Technol. 2000, 131, 400-403. [CrossRef]

216. Fossati, A.; Borgioli, F.; Galvanetto, E.; Bacci, T. Corrosion resistance properties of glow-discharge nitrided AISI 316L austenitic stainless steel in $\mathrm{NaCl}$ solutions. Corros. Sci. 2006, 48, 1513-1527. [CrossRef]

217. Saravanan, P.; Raja, V.S.; Mukherjee, S. Effect of alloyed molybdenum on corrosion behavior of plasma immersion nitrogen ion implanted austenitic stainless steel. Corros. Sci. 2013, 74, 106-115. [CrossRef]

218. Buhagiar, J.; Dong, H. Corrosion properties of S-phase layers formed on medical grade austenitic stainless steel. J. Mater. Sci. Mater. Med. 2012, 23, 271-281. [CrossRef]

219. Lei, M.K.; Zhang, Z.L.; Zhu, X.M. Effects of nitrogen-induced hcp martensite formation on corrosion resistance of plasma source ion nitrided austenitic stainless steel. J. Mater. Sci. Lett. 1999, 18, 1537-1538. [CrossRef]

220. Picard, S.; Memet, J.B.; Sabot, R.; Grosseau-Poussard, J.L.; Rivière, J.P.; Meilland, R. Corrosion behaviour, microhardness and surface characterisation of low energy, high current ion implanted austenitic stainless steel. Mater. Sci. Eng. A 2001, 303, 163-172. [CrossRef]

221. Frangini, S.; Cristofaro, N. De Analysis of the galvanostatic polarization method for determining reliable pitting potentials on stainless steels in crevice-free conditions. Corros. Sci. 2003, 45, 2769-2786. [CrossRef]

222. Abreu, C.M.; Cristóbal, M.J.; Merino, P.; Nóvoa, X.R.; Pena, G.; Pérez, M.C. Electrochemical behaviour of an AISI 304L stainless steel implanted with nitrogen. Electrochim. Acta 2008, 53, 6000-6007. [CrossRef]

223. Martinesi, M.; Stio, M.; Treves, C.; Borgioli, F. Biocompatibility studies of low temperature nitrided and collagen-I coated AISI 316L austenitic stainless steel. J. Mater. Sci. Mater. Med. 2013, 24, 1501-1513. [CrossRef]

224. Stio, M.; Martinesi, M.; Treves, C.; Borgioli, F. Cultures and co-cultures of human blood mononuclear cells and endothelial cells for the biocompatibility assessment of surface modified AISI 316L austenitic stainless steel. Mater. Sci. Eng. C 2016, 69. [CrossRef] [PubMed]

225. Zhu, X.M.; Guo, Y.; Xing, Z.Q.; Lei, M.K. Effect of Nitrogen on Semiconducting Properties of Passive Films of a High Nitrogen Face-Centered-Cubic Phase Formed on Austenitic Stainless Steel. J. Electrochem. Soc. 2012, 159, C319-C325. [CrossRef]

226. Bou-Saleh, Z.; Shahryari, A.; Omanovic, S. Enhancement of corrosion resistance of a biomedical grade 316LVM stainless steel by potentiodynamic cyclic polarization. Thin Solid Films 2007, 515, 4727-4737. [CrossRef]

227. Anandan, C.; Grips, V.K.W.; Selvi, V.E.; Rajam, K.S. Electrochemical studies of stainless steel implanted with nitrogen and oxygen by plasma immersion ion implantation. Surf. Coat. Technol. 2007, 201, 7873-7879. [CrossRef]

228. Bottoli, F.; Jellesen, M.S.; Christiansen, T.L.; Winther, G.; Somers, M.A.J. High temperature solution-nitriding and low-temperature nitriding of AISI 316: Effect on pitting potential and crevice corrosion performance. Appl. Surf. Sci. 2018, 431, 24-31. [CrossRef]

229. Lei, M.K.; Zhu, X.M. In vitro corrosion resistance of plasma source ion nitrided austenitic stainless steels. Biomaterials 2001, 22, 641-647. [CrossRef]

230. Stio, M.; Martinesi, M.; Treves, C.; Borgioli, F. In vitro response of human peripheral blood mononuclear cells to AISI 316L austenitic stainless steel subjected to nitriding and collagen coating treatments. J. Mater. Sci. Mater. Med. 2015, 26. [CrossRef]

231. Yazıc1, M.; Çomakl1, O.; Yetim, T.; Yetim, A.F.; Çelik, A. The effect of plasma nitriding temperature on the electrochemical and semiconducting properties of thin passive films formed on 316L stainless steel implant material in SBF solution. Surf. Coat. Technol. 2015, 261, 181-188. [CrossRef]

232. Sun, Y. Corrosion behaviour of low temperature plasma carburised 316L stainless steel in chloride containing solutions. Corros. Sci. 2010, 52, 2661-2670. [CrossRef]

233. Martin, F.J.; Natishan, P.M.; Lemieux, E.J.; Newbauer, T.M.; Rayne, R.J.; Bayles, R.A.; Kahn, H.; Michal, G.M.; Ernst, F.; Heuer, A.H. Enhanced Corrosion Resistance of Stainless Steel Carburized at Low Temperature. Metall. Mater. Trans. A 2009, 40, 1805-1810. [CrossRef]

234. Ceschini, L.; Chiavari, C.; Lanzoni, E.; Martini, C. Low-temperature carburised AISI 316L austenitic stainless steel: Wear and corrosion behaviour. Mater. Des. 2012, 38, 154-160. [CrossRef]

235. Martin, F.J.; Lemieux, E.J.; Newbauer, T.M.; Bayles, R.A.; Natishan, P.M.; Kahn, H.; Michal, G.M.; Ernst, F.; Heuer, A.H. Carburization-induced passivity of $316 \mathrm{~L}$ austenitic stainless steel. Electrochem. Solid-State Lett. 2007, 10, C76-C78. [CrossRef] 
236. Heuer, A.H.; Kahn, H.; Ernst, F.; Michal, G.M.; Hovis, D.B.; Rayne, R.J.; Martin, F.J.; Natishan, P.M. Enhanced corrosion resistance of interstitially hardened stainless steel: Implications of a critical passive layer thickness for breakdown. Acta Mater. 2012, 60, 716-725. [CrossRef]

237. Metikoš-Huković, M.; Babić, R.; Grubač, Z.; Petrović, Ž.; Lajçi, N. High corrosion resistance of austenitic stainless steel alloyed with nitrogen in an acid solution. Corros. Sci. 2011, 53, 2176-2183. [CrossRef]

238. Zagorski, K.; Doraczynska, A. Potentiodynamic polarization behaviour of two $17 \mathrm{Cr}-13 \mathrm{Ni}-2 \cdot 5 \mathrm{Mo}$ austenitic steels with different N contents. Corros. Sci. 1976, 16, 405-410. [CrossRef]

239. Belfrouh, A.; Masson, C.; Vouagner, D.; de Becdelievre, A.M.; Prakash, N.S.; Audouard, J.P. The cumulative effect of alloying elements $\mathrm{N}, \mathrm{W}, \mathrm{Mo}$ and $\mathrm{Cu}$ on the corrosion behaviour of $17 \mathrm{Cr}-13 \mathrm{Ni}$ stainless steel in $2 \mathrm{~N}$ $\mathrm{H}_{2} \mathrm{SO}_{4}$. Corros. Sci. 1996, 38, 1639-1648. [CrossRef]

240. Kuczynska-Wydorska, M.; Flis, J. Corrosion and passivation of low-temperature nitrided AISI 304L and 316L stainless steels in acidified sodium sulphate solution. Corros. Sci. 2008, 50, 523-533. [CrossRef]

241. Flis, J.; Gajek, A. Impedance parameters of nitrided 304L stainless steel in an acidified sulphate solution. J. Electroanal. Chem. 2001, 515, 82-90. [CrossRef]

242. Wang, K.S.; Tong, S.; Lei, M.K. Corrosion and Passivation of High Nitrogen Face-Centered-Cubic Phase Formed on AISI 304L Austenitic Stainless Steel in Borate Buffer Solution. J. Electrochem. Soc. 2015, 162, C601-C609. [CrossRef]

243. Tian, R.; Sun, J.; Wang, L. Plasma-nitrided austenitic stainless steel 316L as bipolar plate for PEMFC. Int. J. Hydrog. Energy 2006, 31, 1874-1878. [CrossRef]

244. Kaestner, P.; Michler, T.; Weidner, H.; Rie, K.-T.; Bräuer, G. Plasma nitrided austenitic stainless steels for automotive hydrogen applications. Surf. Coat. Technol. 2008, 203, 897-900. [CrossRef]

245. Lin, K.; Li, X.; Sun, Y.; Luo, X.; Dong, H. Active screen plasma nitriding of 316 stainless steel for the application of bipolar plates in proton exchange membrane fuel cells. Int. J. Hydrog. Energy 2014, 39, 21470-21479. [CrossRef]

246. Bagayoko, D.; Callaway, J. Lattice-parameter dependence of ferromagnetism in bcc and fcc iron. Phys. Rev. B 1983, 28, 5419-5422. [CrossRef]

247. Moruzzi, V.L.; Marcus, P.M.; Schwarz, K.; Mohn, P. Ferromagnetic phases of bcc and fcc Fe, Co, and Ni. Phys. Rev. B 1986, 34, 1784-1791. [CrossRef]

248. Keune, W.; Halbauer, R.; Gonser, U.; Lauer, J.; Williamson, D.L. Antiferromagnetism of fcc Fe thin films. J. Appl. Phys. 1977, 48, 2976-2979. [CrossRef]

249. Shirane, G.; Takei, W.J.; Ruby, S.L. Mössbauer study of hyperfine fields and isomer shifts in $\mathrm{Fe}_{4} \mathrm{~N}$ and $(\mathrm{Fe}, \mathrm{Ni})_{4}$ N. Phys. Rev. 1962, 126, 49-52. [CrossRef]

250. Basso, R.L.O.; Pimentel, V.L.; Weber, S.; Marcos, G.; Czerwiec, T.; Baumvol, I.J.R.; Figueroa, C.A. Magnetic and structural properties of ion nitrided stainless steel. J. Appl. Phys. 2009, 105, 124914. [CrossRef]

251. Baranowska, J. Characteristic of the nitride layers on the stainless steel at low temperature. Surf. Coat. Technol. 2004, 180-181, 145-149. [CrossRef]

252. Öztürk, O.; Okur, S.; Riviere, J.P. Structural and magnetic characterization of plasma ion nitrided layer on 316L stainless steel alloy. Nucl. Instrum. Methods Phys. Res. Sect. B Beam Interact. with Mater. Atoms 2009, 267, 1540-1545. [CrossRef]

253. Brink, B.; Ståhl, K.; Christiansen, T.L.; Somers, M.A.J. Thermal expansion and phase transformations of nitrogen-expanded austenite studied with $\{\backslash$ it in situ\} synchrotron X-ray diffraction. J. Appl. Crystallogr. 2014, 47, 819-826. [CrossRef]

254. Menéndez, E.; Martinavicius, A.; Liedke, M.O.; Abrasonis, G.; Fassbender, J.; Sommerlatte, J.; Nielsch, K.; Suriñach, S.; Baró, M.D.; Nogués, J.; et al. Patterning of magnetic structures on austenitic stainless steel by local ion beam nitriding. Acta Mater. 2008, 56, 4570-4576. [CrossRef]

255. Quéré, D. Wetting and Roughness. Annu. Rev. Mater. Res. 2008, 38, 71-99. [CrossRef]

256. Feng, X.; Jiang, L. Design and creation of superwetting/antiwetting surfaces. Adv. Mater. 2006, 18, $3063-3078$. [CrossRef]

257. Wenzel, R.N. Resistance of solid surfaces to wetting by water. Ind. Eng. Chem. 1936, 28, 988-994. [CrossRef]

258. Cassie, A.B.D.; Baxter, S. Wettability of porous surfaces. Trans. Faraday Soc. 1944, 40, 546-551. [CrossRef]

259. Buhagiar, J.; Bell, T.; Sammons, R.; Dong, H. Evaluation of the biocompatibility of S-phase layers on medical grade austenitic stainless steels. J. Mater. Sci. Mater. Med. 2011, 22, 1269-1278. [CrossRef] 
260. Braz, J.K.F.S.; Martins, G.M.; Sabino, V.; Vitoriano, J.O.; Barboza, C.A.G.; Soares, A.K.M.C.; Rocha, H.A.O.; Oliveira, M.F.; Alves Júnior, C.; Moura, C.E.B. Plasma nitriding under low temperature improves the endothelial cell biocompatibility of 316L stainless steel. Biotechnol. Lett. 2019, 41, 503-510. [CrossRef]

261. Mantel, M.; Wightman, J.P. Influence of the surface chemistry on the wettability of stainless steel. Surf. Interface Anal. 1994, 21, 595-605. [CrossRef]

262. Takata, Y.; Hidaka, S.; Kohno, M. Wettability improvement by plasma irradiation and its applications to phase-change phenomena. Heat Transf. Eng. 2009, 30, 549-555. [CrossRef]

263. Bordji, K.; Jouzeau, J.-Y.; Mainard, D.; Payan, E.; Delagoutte, J.-P.; Netter, P. Evaluation of the effect of three surface treatments on the biocompatibility of $316 \mathrm{~L}$ stainless steel using human differentiated cells. Biomaterials 1996, 17, 491-500. [CrossRef]

264. Martinesi, M.; Bruni, S.; Stio, M.; Treves, C.; Bacci, T.; Borgioli, F. Biocompatibility evaluation of surface-treated AISI 316L austenitic stainless steel in human cell cultures. J. Biomed. Mater. Res._Part A 2007, 80, 131-145. [CrossRef]

(C) 2020 by the author. Licensee MDPI, Basel, Switzerland. This article is an open access article distributed under the terms and conditions of the Creative Commons Attribution (CC BY) license (http://creativecommons.org/licenses/by/4.0/). 